\title{
A!
}

Aalto University

School of Electrical

Engineering

\section{Analysis of deep-heat energy wells for heat pump systems}

\author{
Andreas Lund
}

Thesis submitted for examination for the degree of Master of Science in Technology.

Espoo 20.11.2019

Supervisor: Professor Matti Lehtonen

Advisor: Dr. Timo Karvinen 
Tekijä Andreas Lund

Työn nimi Syvälämpökaivon analysointi lämpöpumppujärjestelmissä

Maisteriohjelma Advanced Energy Solutions $\quad$ Koodi ELEC3048

Työn valvoja Professori Matti Lehtonen

Työn ohjaaja(t) TkT Timo Karvinen

Päivämäärä 20.11.2019 Sivumäärä $71 \quad$ Kieli Englanti

\section{Tiivistelmä}

Syväkaivolämpö on uusi lupaava lämmönlähde lämpöpumpuille. Se on jopa kymmenen kertaa syvempi kuin perinteiset porareiät, jolloin se pystyy ottamaan huomattavasti enemmän lämpöä samalta pinta-alalta mahdollistaen lämpöpumppujen laajemman käytön kaupunkialueilla. Tässä diplomityössä tutkittiin perusteellisesti syväkaivojen lämpöteknistä toimintaa ja suorituskykyä. Työssä laadittiin simulointimalli syväkaivolle COMSOL Multiphysics -ohjelmiston avulla.

Syväkaivon toimintaan vaikuttavat monet geofysikaaliset ja lämpötekniset parametrit ja tekniset ratkaisut. Esimerkiksi korkeampi kallion lämmön johtavuus ja lämpögradientti parantaa syväkaivon lämmön tuotantoa. Virtausnopeus ja sisään menevän nesteen lämpötila vaikuttavat suuresti kaivon suorituskykyyn.

Simuloinnit osoittavat, että 2 km syvä koaksiaalinen lämpökaivo voisi tuottaa lämpöä 110 kW (55 $\mathrm{W} / \mathrm{m}$ ) tasapainotilassa. Syväkaivon vuosituotto on tällöin jopa 30-kertainen tavanomaiseen porareikään verrattuna.

Työssä tutkittiin myös erilaisia toimintastrategioita. Syväkaivoa voidaan käyttää lämmön varastointiin esimerkiksi 'power-to-heat'-konversion yhteydessä mahdollistaen lyhyillä latausjaksoilla jopa 1 MW lataustehon. Useampia kaivoja käytettäessä suorituskyky paranee, mutta kaivot alkavat vuorovaikuttamaan vahvemmin keskenään, kun niiden määrä kasvaa yli neljän, mikä tiputtaa yhdestä kaivosta saatavan lämmön määrää.

Syväkaivoon liittyy erityispiirteitä sen pituudesta johtuen. Termisen oikosulun välttämiseksi on suositeltavaa käyttää tyhjiöputkiratkaisua muoviputkien sijaan, jotka saattavat pudottaa saatavan lämpötehon jopa puoleen. Lämmönsiirtonesteen virtausnopeuden optimaalinen asetus on myös tärkeää, koska pumppaukseen tarvittava sähkö voi helposti pudottaa lämpöpumpun lämpökerrointa $10 \%$ tai jopa enemmän, jos virtausnopeus on optimiarvoa paljon korkeampi.

Diplomityön johtopäätökset painottavat syväkaivojen huolellista suunnittelua ja erityisesti erilaisten lämpö- ja geoteknisten seikkojen huomioon ottamista, kun edetään käytännön projekteihin. Syväkaivojen kattava optimointi olisi tulevaisuudessa hyödyksi suunnittelukäytäntöjen vakiinnuttamiseksi.

Avainsanat Syvälämpökaivo, geoterminen lämpö, lämpöpumppu, porareikä, lämpö-analyysi 


\begin{tabular}{|c|c|}
\hline \multirow{2}{*}{\multicolumn{2}{|c|}{$\begin{array}{l}\text { Author Andreas Lund } \\
\text { Title of thesis Analysis of deep-heat energy wells for heat pump systems }\end{array}$}} \\
\hline & \\
\hline Master programme Advanced Energy Solutions & Code ELEC3048 \\
\hline \multicolumn{2}{|l|}{ Thesis supervisor Professor Matti Lehtonen } \\
\hline \multicolumn{2}{|l|}{ Thesis advisor(s) Dr. Timo Karvinen } \\
\hline Number of pages 71 & Language English \\
\hline
\end{tabular}

\begin{abstract}
Deep-heat wells in bedrock are a new potential heat source for heat pumps. With a depth up to ten-fold compared to state-of-the-art boreholes, a deep-heat well could extract much more heat from the same area enabling installation of heat pumps in densely populated areas. In this thesis, comprehensive thermal analyses were made to better understand the performance of such systems. For this purpose, a simulation model for deep-heat wells was developed with the COMSOL Multiphysics software.
\end{abstract}

The performance of a deep well is influenced by many geophysical, thermophysical, and engineering factors. For example, a higher thermal conductivity and thermal gradient increases the thermal output of the borehole heat exchanger. There is a strong link between the well performance and inlet temperature of fluid and mass flow rate.

The simulations indicate that a $2 \mathrm{~km}$ deep well with a coaxial borehole heat exchanger produces $110 \mathrm{~kW}(55 \mathrm{~W} / \mathrm{m})$ at steady state. The yearly heat energy output would be 30 -fold compared to a traditional borehole.

Different operational strategies and well configurations were also analyzed. The deep-heat well can be used for heat storage, e.g. with power-to-heat schemes enabling quite high charging power levels up to $1 \mathrm{MW}$ for shorter periods. Using multiple wells increases the overall performance, but the wells start to interfere each other's performance with more than four wells with $30 \mathrm{~m}$ well distance.

The borehole heat exchanger contains some special issues due to its length. To avoid thermal short-circuiting, a vacuum tube type of solution is recommended instead of plastic pipes, which could drop the heat output by even $50 \%$. Setting an optimal flow rate is also important, as the electricity needed for pumping the heat transfer fluid could easily reduce the system COP by up to $10 \%$, or even more in non-optimal systems.

The thesis results emphasize careful planning and design of deep-heat systems, in particular in geoengineering and thermal engineering, when moving to practical pilot project. Comprehensive optimization of deep-heat systems would be relevant for future work to establish standard designs for practitioners.

Keywords Deep-heat well, geothermal heat, heat pumps, boreholes, thermal analysis 



\section{Preface}

This Master's thesis has been done at Granlund Consulting Ltd. I thank Dr. Tuomo Niemelä for giving this interesting opportunity to work on such an inspiring topic.

I would like to thank my instructor Dr. Timo Karvinen for his excellent guidance throughout the whole work, for his valuable insights, and introducing me to the 'COMSOL' world. The supervisor, Prof. Matti Lehtonen, provided initial directions and gave valuable comments to the thesis.

I also thank my colleagues at Granlund Consulting Ltd. for a pleasant working atmosphere and for good discussions along the work.

Finally, I would like to thank my parents, 'äiti ja isä', for their support and encouragement, and also for their advices that have brought me forward in my life. Sonja deserves my special thanks for her encouragement.

Espoo 20.11.2019

Andreas Lund 


\section{Table of Contents}

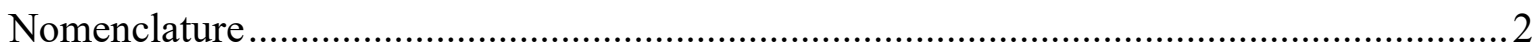

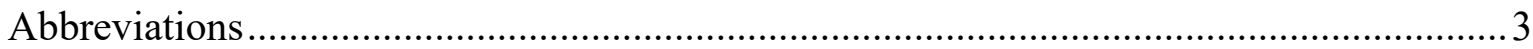

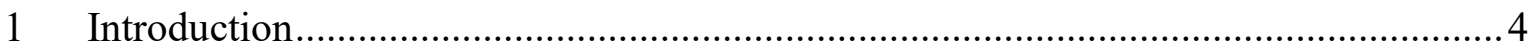

$1.1 \quad$ Objectives

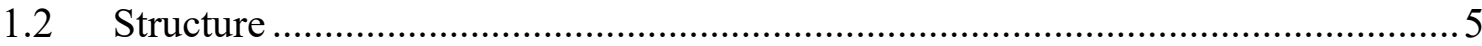

2 Introduction to geothermal energy and its utilization .................................................

3 Principle of a geothermal heat pump system ........................................................

3.1 Operating principle of a heat pump …………………………………………....

$3.2 \quad$ Heat sources and heat collection systems …………………………………........ 11

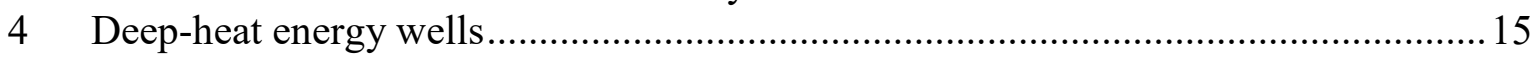

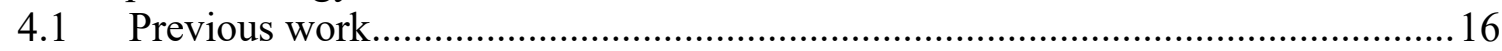

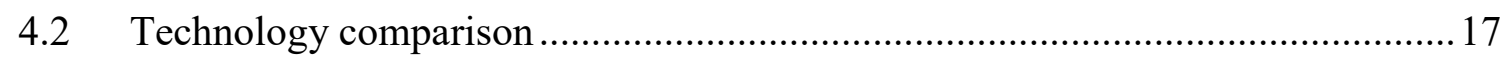

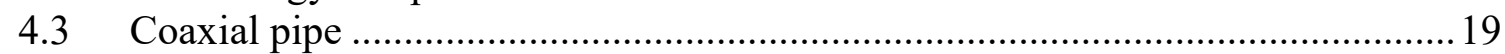

4.4 Operation of a deep borehole exchanger...…………………………………. 20

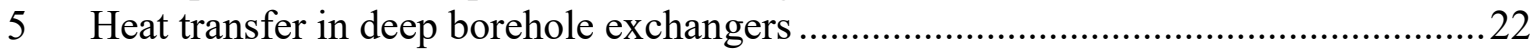

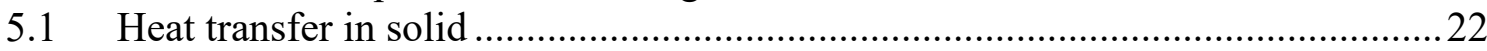

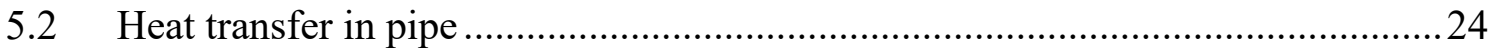

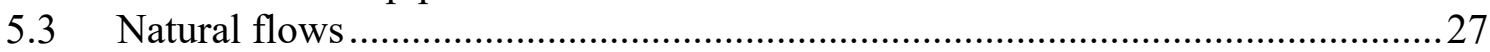

6 COMSOL Multiphysics Simulation Model ……………………………………........29

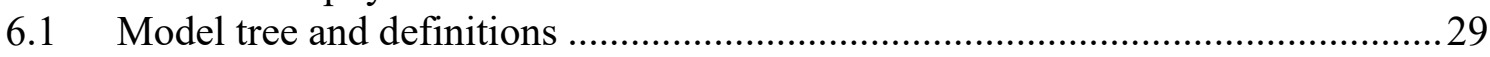

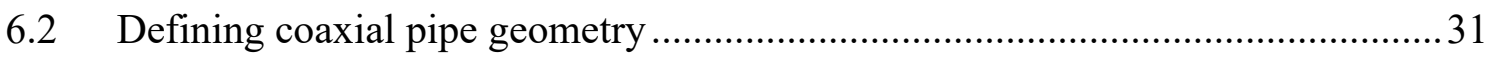

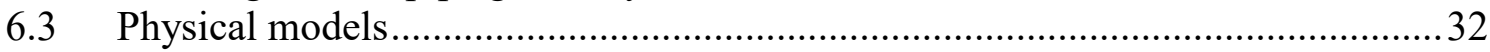

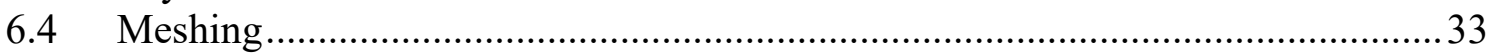

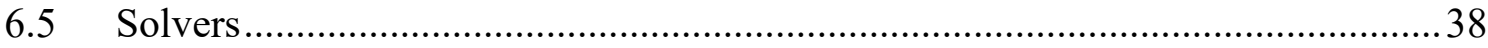

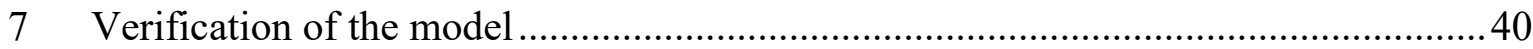

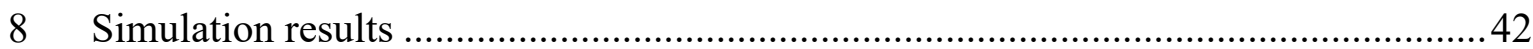

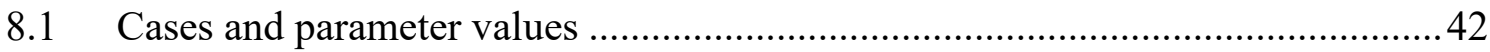

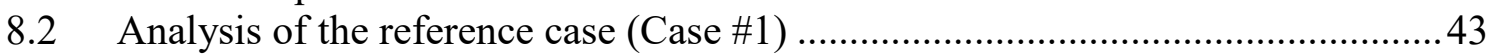

8.3 Thermal short-circuiting in borehole heat exchanger .............................................4 46

8.4 Effects of bedrock characteristics ........................................................................ 47

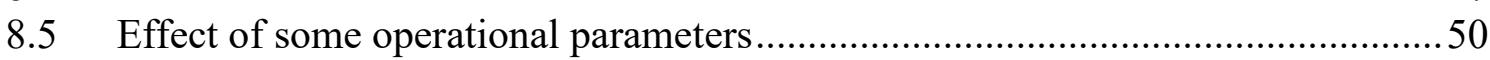

8.6 Effects of different operational strategies ……………........................................5

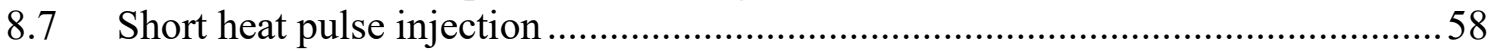

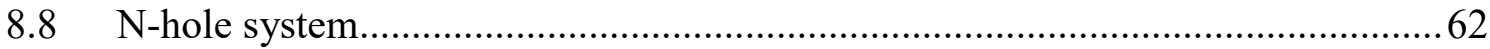

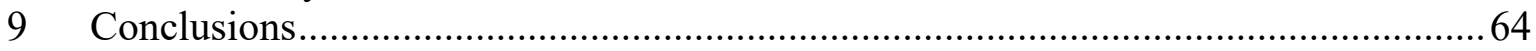

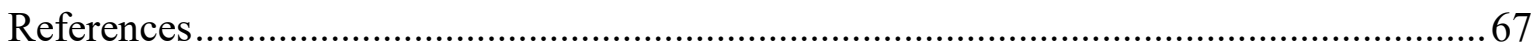




\section{Nomenclature}

\begin{tabular}{|c|c|c|}
\hline$A$ & {$\left[\mathrm{~m}^{2}\right]$} & cross section area \\
\hline$c_{p}$ & {$[\mathrm{~J} / \mathrm{kgK}]$} & specific heat capacity \\
\hline$D$ & {$[1 / \mathrm{s}]$} & strain rate tensor \\
\hline $\mathrm{d}$ & {$[\mathrm{m}]$} & pipe diameter \\
\hline$d_{h}$ & {$[\mathrm{~m}]$} & hydraulic diameter \\
\hline$E$ & {$[\mathrm{~J}]$} & internal energy \\
\hline$f_{D}$ & {$[-]$} & friction factor \\
\hline$h$ & {$\left[\mathrm{~W} / \mathrm{m}^{2} \mathrm{~K}\right]$} & heat transfer coefficient \\
\hline$k$ & {$[\mathrm{~W} / \mathrm{mK}]$} & thermal conductivity \\
\hline$L$ & {$[\mathrm{~m}]$} & length of borehole \\
\hline$\dot{m}$ & {$[\mathrm{~kg} / \mathrm{s}]$} & mass flow rare \\
\hline$n$ & {$[-]$} & number of holes of gas \\
\hline$q$ & {$\left[\mathrm{~W} / \mathrm{m}^{2}\right]$} & heat flux density \\
\hline$q^{\prime}$ & {$[\mathrm{W} / \mathrm{m}]$} & heat flux per unit length \\
\hline$Q$ & {$[\mathrm{~W}]$} & power, heat source \\
\hline$Q_{p}$ & {$[\mathrm{~W} / \mathrm{m}]$} & pressure work per unit time and length \\
\hline$Q^{\prime}$ & {$[\mathrm{W} / \mathrm{m}]$} & heat flux per unit length, heat source \\
\hline$Q^{\prime \prime}$ & {$\left[\mathrm{W} / \mathrm{m}^{3}\right]$} & volumetric heat source \\
\hline$p$ & {$[\mathrm{~Pa}]$} & pressure \\
\hline$R$ & {$[\mathrm{~J} / \mathrm{K} \mathrm{mol}]$} & ideal gas constant \\
\hline$S$ & {$[\mathrm{~Pa}]$} & second Piola-Kirchoff stress tensor \\
\hline$T$ & {$[\mathrm{~K}]$} & temperature \\
\hline$u$ & {$[\mathrm{~m} / \mathrm{s}]$} & fluid velocity \\
\hline$V$ & {$\left[\mathrm{~m}^{3}\right]$} & volume \\
\hline$Z$ & {$[\mathrm{~m}]$} & wall perimeter \\
\hline$\alpha$ & {$[1 / \mathrm{K}]$} & coefficient of thermal expansion \\
\hline$\beta$ & {$[1 / \mathrm{K}]$} & coefficient of volumetric expansion \\
\hline$\eta_{C A}$ & {$[-]$} & Carnot non-ideality factor \\
\hline$\eta_{m}$ & {$[-]$} & mechanical efficiency of the compressor \\
\hline$\lambda$ & {$[\mathrm{W} / \mathrm{mK}]$} & thermal conductivity \\
\hline$\rho$ & {$\left[\mathrm{kg} / \mathrm{m}^{3}\right]$} & density \\
\hline$\Phi$ & {$[\mathrm{W}]$} & thermal power of the heat pump system \\
\hline
\end{tabular}

Subscripts

c

comp

cond

evap

ext

f

g

int

$\mathrm{p}$

pump

r conduction

compressor

condenser

evaporator

outside of pipe wall

fluid

ground

inside of tube

pipe

pump

radiation 
trans

\section{Abbreviations}

BHE

$\mathrm{CO}_{2}$

$\mathrm{COP}$

GG

$\mathrm{Gr}$

GSHP

HP

IEA

$\mathrm{Nu}$

$\operatorname{Pr}$

$\mathrm{Ra}$

$\mathrm{Re}$

SCOP

$\mathrm{SPF}$ translational motion 


\section{Introduction}

Mitigation of the climate change will require drastic reductions in the use of fossil fuels in the future (IPCC, 2007). To reach the $1.5^{\circ} \mathrm{C}$-goal of the Paris Climate Agreement would require that carbon emissions and carbon sinks to be in balance by the middle of this century. In the second half of the century, emissions should even be negative (IPCC, 2014). Accordingly, the recent programme by the Finnish government program plans to reach carbon neutrality already in 2035 (Valtioneuvosto, 2019), which will require drastic reductions in $\mathrm{CO}_{2}$ emissions in the coming years.

The built environment accounts for almost two thirds of all energy use in the world and is therefore a key factor in cutting emissions (IEA, 2017). Heating of buildings accounts for $27 \%$ of all energy used in Finland (Statistics Finland, 2017). District heating accounts for most of the heating in urban areas, but in large cities it is still often based on fossil fuel utilization. In Helsinki, for example, more than half of all district heat is produced by coal (Helen, 2018). Replacing fossil-fuel-based heating with heat pumps, which make use of natural clean energy sources, could therefore be a promising option to cut emissions in the heating sector.

Heat pumps are becoming very popular in single-family houses, which could potentially be extended to apartment and larger buildings as well. This may, however, require the use of new types of heat sources and heat storage to match the scale needed in district heating. At the same time, electrification of energy systems through the increased use of renewable electricity sources could also support this kind of development. Electrification of the heating sector through more heat pumps could then also offer new options of balancing the use of large-scale variable renewable electricity schemes.

\subsection{Objectives}

Motivated by the positive outlook of large-scale heat pump use in the future, the aim of this work is to assess the feasibility of so-called deep-well heat sources for heat pumps in Finnish conditions. The objective is to analyze the geothermal performance and dynamics of deepwells to establish basic design guidelines for their use.

Deep wells constitute a new potential heat source for heat pumps. Their depth could extend down to 1-3 km, which is ten-fold compared to a state-of-the-art well, e.g. a borehole in rock. In this way, more heat could be extracted from smaller areas enabling use of heat pump heating in more densely populated districts. The thesis aims at providing a more solid base for designing such systems in the future, and thus fill the existing knowledge gap for practical applications.

An analysis of deep-heat wells for Finnish conditions is highly motivated also by the fact that results from international studies cannot be directly applied locally, due to different geological and climatic conditions, but also due to different building codes and regulations. 


\subsection{Structure}

As no previous practical experience on deep-wells in Finland exist, an extensive theoretical study on deep-wells is undertaken in this thesis. This includes a state-of-the-art review and construction of a simulation model for a deep well, which allows accurate heat transfer and thermal analysis of well operation under different conditions. The effect of various operating strategies for the wells, e.g. different discharging and charging cycles, on the performance of a well is also explored using the model. Thermal analyses of different deep-well configurations were performed. This also includes a sensitivity analysis against key design parameters.

The main specific research questions of the thesis are the following:

1. Assess the thermal performance, charge and discharge capacity of deep wells as a heat source and heat storage;

2. Assess the thermal impact of heat extraction from deep wells on the surrounding environment over time;

3. Assess the impact of on different uncertainties on heat availability from deep wells;

4. Establish strategies for optimal use of a deep-well including optimum charge and discharge profiles;

5. Assess other possible uses for deep-wells, e.g. as part of power-to-heat conversion and heat storage of electricity.

The thesis work has been done at Granlund Consulting Ltd. and in the Advanced Energy Solutions Programme of Aalto University. The thesis is structured as follows: Section 2 describes geothermal energy utilization in general; Section 3 describes the principles of geothermal heat pump systems; Section 4 describes the deep well technology in detail; Section 5 includes the heat transfer principles and equations in the deep well; Section 6 describes the COMSOL model and its use for simulating the wells; Section 7 presents the verification of the model. Section 8 presents the major simulation results; Section 9 presents the conclusions. 


\section{Introduction to geothermal energy and its utilization}

Geothermal energy originates from the radioactive decays and nuclear reactions in the rock and from the hot magma deep in the earth. The resulting heat diffuses to the upper layers of the earth's crust, where it can be utilized to generate useful energy by various methods. The upmost layers of the ground down to some meters are also heated up by the solar radiation and ambient air, but this is not classified as traditional primary geothermal heat, but rather as a ground heat source or secondary geothermal heat (Barbier, 1997).

Geothermal energy can be found everywhere and whenever. Its use does not encompass any kind of pollution, but its utilization may indirectly require some energy e.g. for running the pumps that extract the geothermal heat. However, geothermal energy is not classified as a renewable energy source, though it is abundantly available.

Geothermal energy or heat can be utilized in different ways depending on the geological conditions of the site. For example, in volcanic areas such as in Iceland, superheated water at several hundred degrees Celsius from hot springs could directly be exploited for power generation in geothermal power plants (Stevanovic, 2010). In case of hot rock formations, drilling a deep borehole may be enough to extract hot water for heating or even for power production. With dry hot-rock, some kind of water circulation would be necessary, i.e. pumping cold water into the well and extracting then heated water. Such systems are in use in the USA and Italy (Lund \& Boyd, 2016).

The geothermal resource depends on the local geological conditions. In volcanically active regions geothermal heat is found at high temperature close to the ground. In old and stable bedrocks such as in Northern Europe and Finland, the upper layers of the crust have cooled down and the thermal gradient in rock is approximately $10-20{ }^{\circ} \mathrm{C}$ per $\mathrm{km}$ only (Geologian tutkimuskeskus, 2019). To harness geothermal energy directly in Finnish conditions, e.g. for district heating, would require boreholes of 6-7 km depth. Such holes are being tested at the St1-Fortum site in Espoo-Otaniemi (St1, 2018), but this technology is not yet commercial.

The geothermal energy utilization in Finland has therefore mainly been limited to primary geothermal energy utilization with 100-300 m deep bore-holes with stable temperatures in the range of $5-7^{\circ} \mathrm{C}$ or secondary geothermal energy of the upper soil layers heated by solar radiation with varying temperature from freezing conditions to $10-15{ }^{\circ} \mathrm{C}$. In both cases, a heat pump would be necessary to raise the temperature of the heat sources to a useful level. Typically, the effects of ambient temperature in the Finnish bedrock seizes at a depth of 14$15 \mathrm{~m}$ (Pesonen, 2018).

Most of the ground-coupled heat pump systems in Finland employ low geothermal resources less than $300 \mathrm{~m}$ deep, whereas deep geothermal sources starting at a 300-500 m depth have not been exploited. The scope of this work is on these new deep-heat sources at a $1-2 \mathrm{~km}$ depth, where the temperature is $20-40{ }^{\circ} \mathrm{C}$, but still requiring a heat pump system. The main application of such as system would be heating of larger buildings or apartments e.g. in connection with district heating. 


\section{Principle of a geothermal heat pump system}

The principle of a heat pump system employing ground heat is shown in Figure 1. The same principle applies for other geothermal heat pump systems as well. The main components are the heat source, the heat extraction or collection system, and the heat pump, which is connected to the heating system to serve the heat demand such as space heating and domestic hot water.

Basically, a ground-charging function to enable heat storage can easily be realized by reversing the flow and by by-passing the heat pump, e.g. by adding a three-way valve which connects an external heat source to the heat extraction circuit.

In the next, the system will be described in more detail.

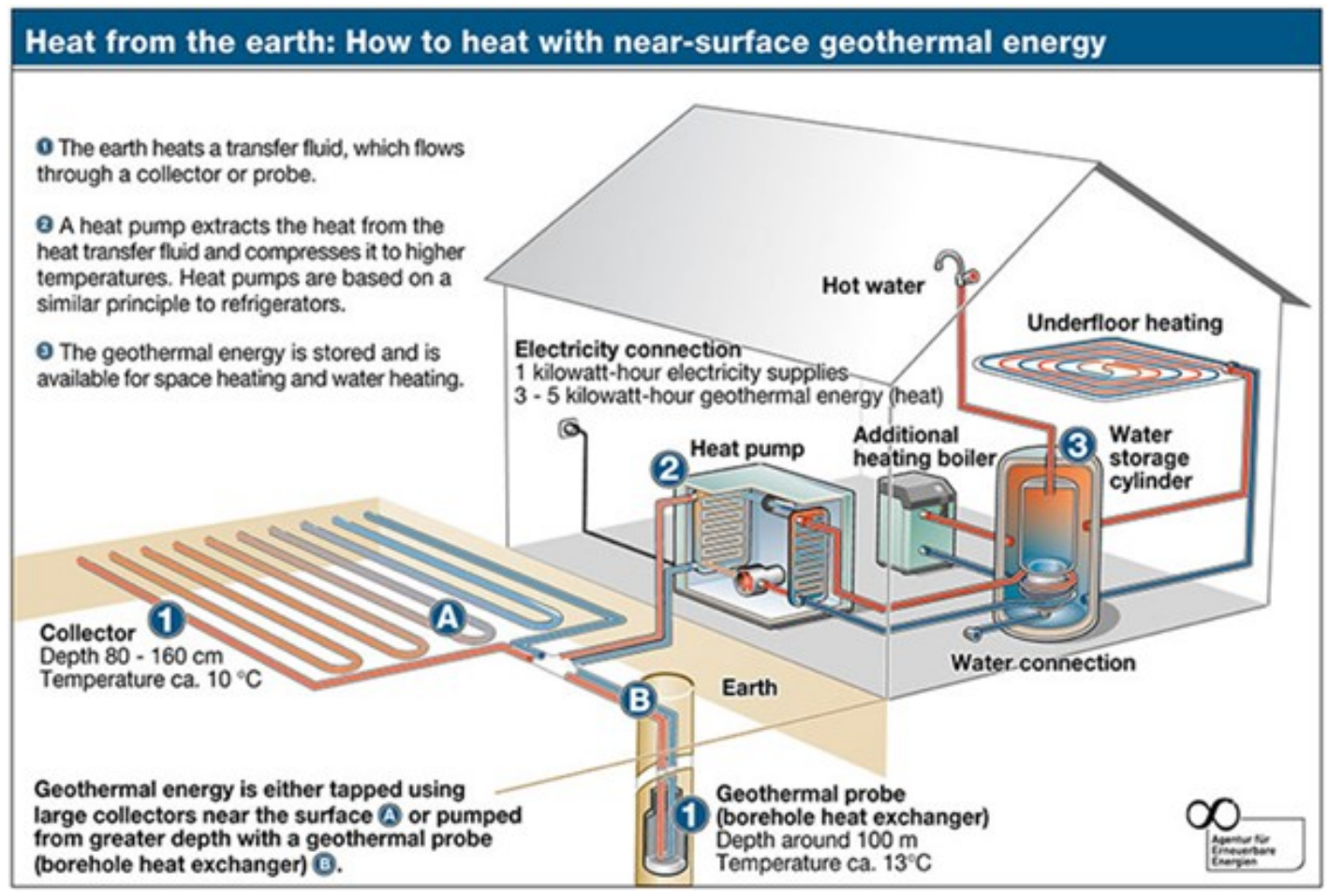

Figure 1. Principle of a ground/geothermal heat pump system (Byrum HVAC, 2019).

\subsection{Operating principle of a heat pump}

To make low-temperature geothermal heat useable, its temperature need to be raised, which takes place in a heat pump. From a thermodynamic point of view, the heat pump is a refrigerating process, which transfers heat between a heat source and a heat sink according to the Carnot-process. (Glassley, 2010)

The operational principle of a heat pump is illustrated in Figure 2. It consists of two circuits: a refrigerant and a heat-extraction circuit, the latter being connected to the heat source. In 
geothermal energy systems, water/liquid-based systems are employed. The core components of the heat pump are the evaporator, compressor, condenser, and expansion valve. The heat pump forms a vapor compression cycle, in which the low temperature heat from the brine circuit is upgraded in the refrigerant cycle into high-quality heat (Lampinen, 2017; Moran, 2014).

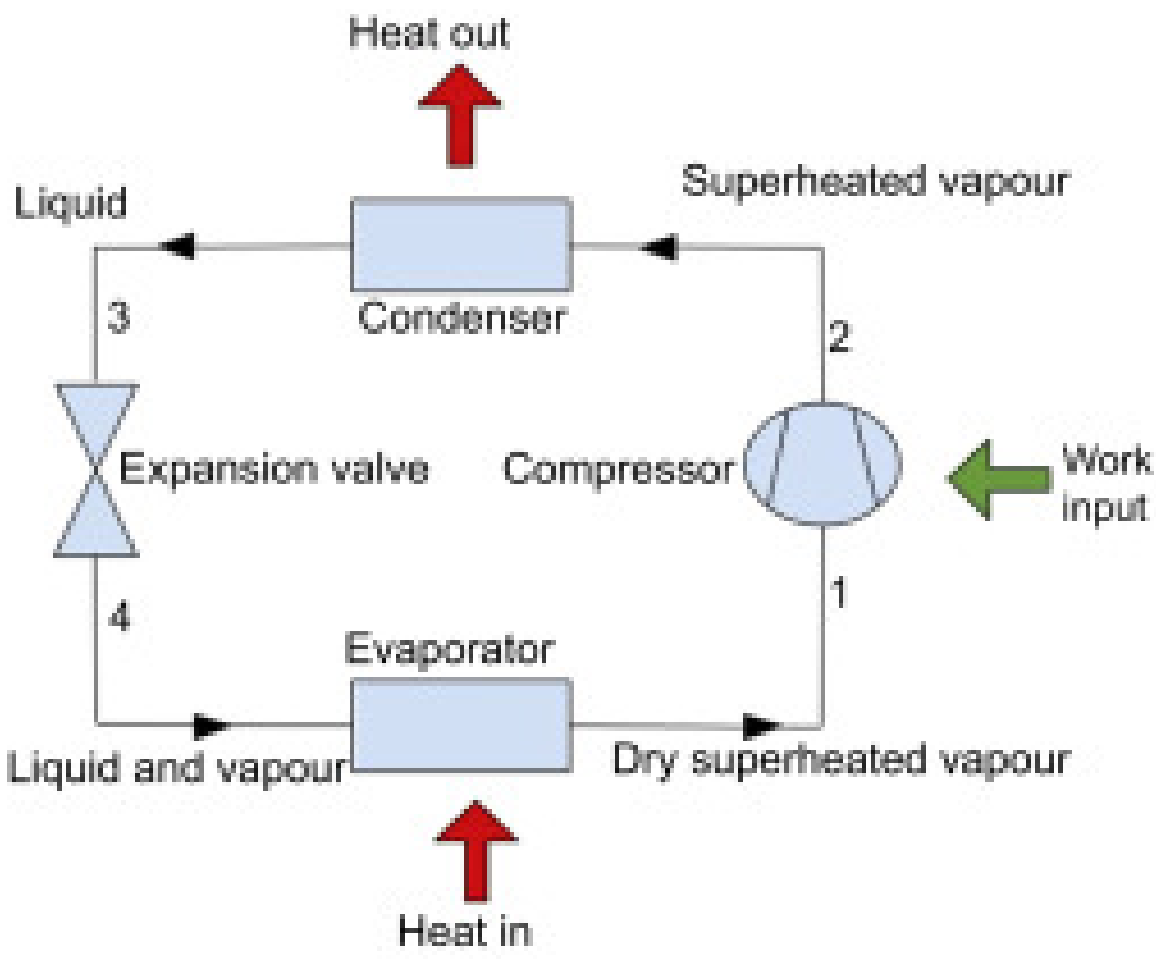

Figure 2. Operating principle of a heat pump (Rees, 2016).

The heat-extraction circuit consists of an open or a closed pipe network. The fluid in this circuit absorbs heat from the ground and vaporizes the refrigerant in the evaporator. The vaporization temperature can be adjusted through the vaporization pressure to match the temperature of the heat source. The (electric) compressor will compress the refrigerant vapor into a high-pressure gas raising the temperature of the gas according to the ideal gas law $(p V=\mathrm{nR} T)$ typically to $50-120^{\circ} \mathrm{C}$ depending on the application. Next, the hot refrigerant gas is condensed to a liquid refrigerant at a high temperature in the condenser. The condensing heat can be utilized for heating. The expansion valve of the heat pump lowers the refrigerant's pressure and consequently also its temperature, even below zero degree. The refrigerant flows back to the evaporator and the process continues from the beginning as described above (Aittomäki et al., 2008).

Based on the $1^{\text {st }}$ law of thermodynamics (energy conservation law), ideally the high-temperature condensing heat $\left(Q_{\text {cond }}\right)$ equals to the low-temperature evaporation heat $\left(Q_{\text {evap }}\right)$ plus the compression power $\left(Q_{\text {comp }}\right)$, i.e. $Q_{c o n d}=Q_{c o m p}+Q_{\text {evap }}$. For the heat pump flows, we generally use the symbol $Q$ to denote for instantaneous power (W), but for simplicity also for energy (Wh) when calculating the yearly performance values. The Coefficient of Performance (COP) of the heat pump, which describes the efficiency or goodness of the heat pumps, is 
obtained when also adding the parasitic electricity use in circulation pumps $\left(Q_{p u m p}\right)$ (Eskola et al., 2012; Laitinen et al., 2014):

$$
\operatorname{COP}_{H P}=\frac{Q_{\text {cond }}}{Q_{\text {comp }}+Q_{\text {pump }}}
$$
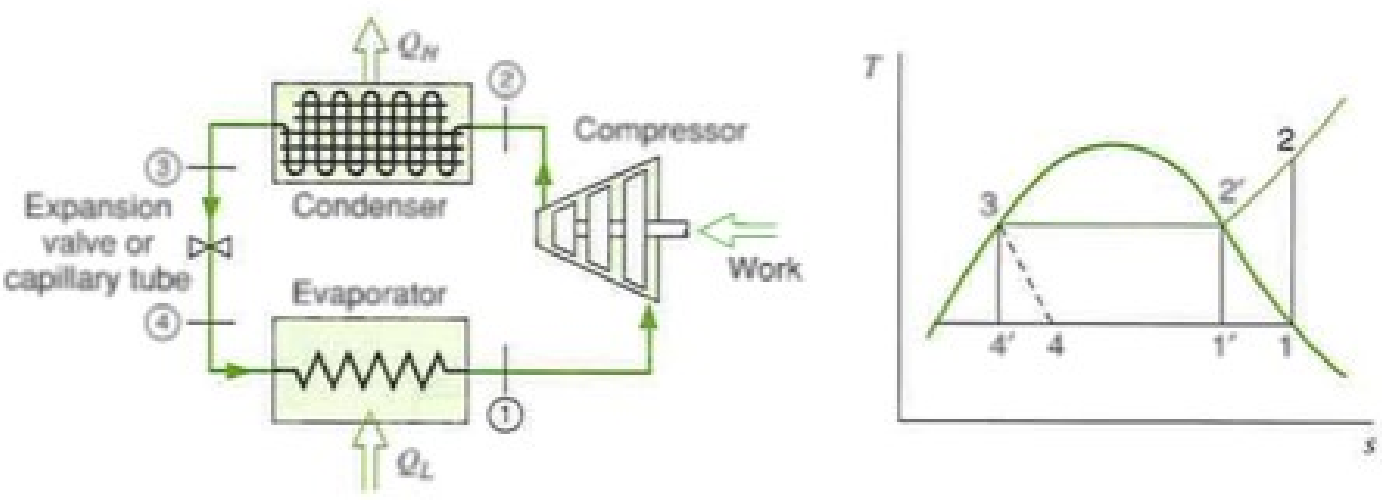

Figure 3. T-s diagram of a heat pump (vapor-compression cycle) (Borgnakke et al. 2009).

From the $2^{\text {nd }}$ law of thermodynamics and the thermodynamic cycle of the heat pump depicted in Fig.3 (temperature - entropy diagram, $d Q=T d s$ ) we can write for the COP of an ideal heat pump (cycle 1'-2'-3-4) a temperature dependent equation as follows (Borgnakke et al. 2009):

$$
C O P_{\text {Carnot }}=\frac{T_{\text {cond }}}{T_{\text {cond }}-T_{\text {evap }}}
$$

where $T_{\text {evap }}=$ evaporating temperature $(\mathrm{K}), T_{\text {cond }}=$ condensing temperature $(\mathrm{K})$.

In practice, there are a range of non-idealities in a heat pump, e.g. in internal heat transfer losses, pressure drops, etc. For a heat-pump in real conditions, we can write

$$
\operatorname{COP}_{H P} \approx \eta_{C A} \eta_{m} \frac{T_{\text {cond }}}{T_{\text {cond }}-T_{\text {evap }}}
$$

where $\eta_{C A}=$ Carnot non-ideality factor $(0.45-0.55), \eta_{m}=$ mechanical efficiency of the compressor (0.90-0.95) (Lund, 1984). Due to the heat exchanger and piping losses and non-ideal heat transfer, the heat source and application temperatures cannot be directly be used in Eq. (3). The condensing and evaporating temperatures in Eq. (3) need typically be adjusted by $\Delta \mathrm{T}=5-10 \mathrm{~K}$, i.e. the condensing temperature $=$ application temperature $+\Delta \mathrm{T}$ and evaporation temperature $=$ heat source temperature $-\Delta \mathrm{T}$, respectively.

The COP of the heat pump strongly depends on the temperature levels of the source $\left(T_{\text {evap }}\right)$ and the application $\left(T_{c o n d}\right)$ and on their difference as described by Eq. (3). The COP for a 
range of temperature levels is illustrated in Figure 4 for a case example. The increasing trend of the COP with higher heat source temperatures is well demonstrated, and the trend is strengthened at lower heat delivery temperatures. With parameter values typical for singlefamily house ground-heat pump systems, a COP of 3-4 could be expected in Finnish condition (Sanner et al., 2003; Motiva, 2014).

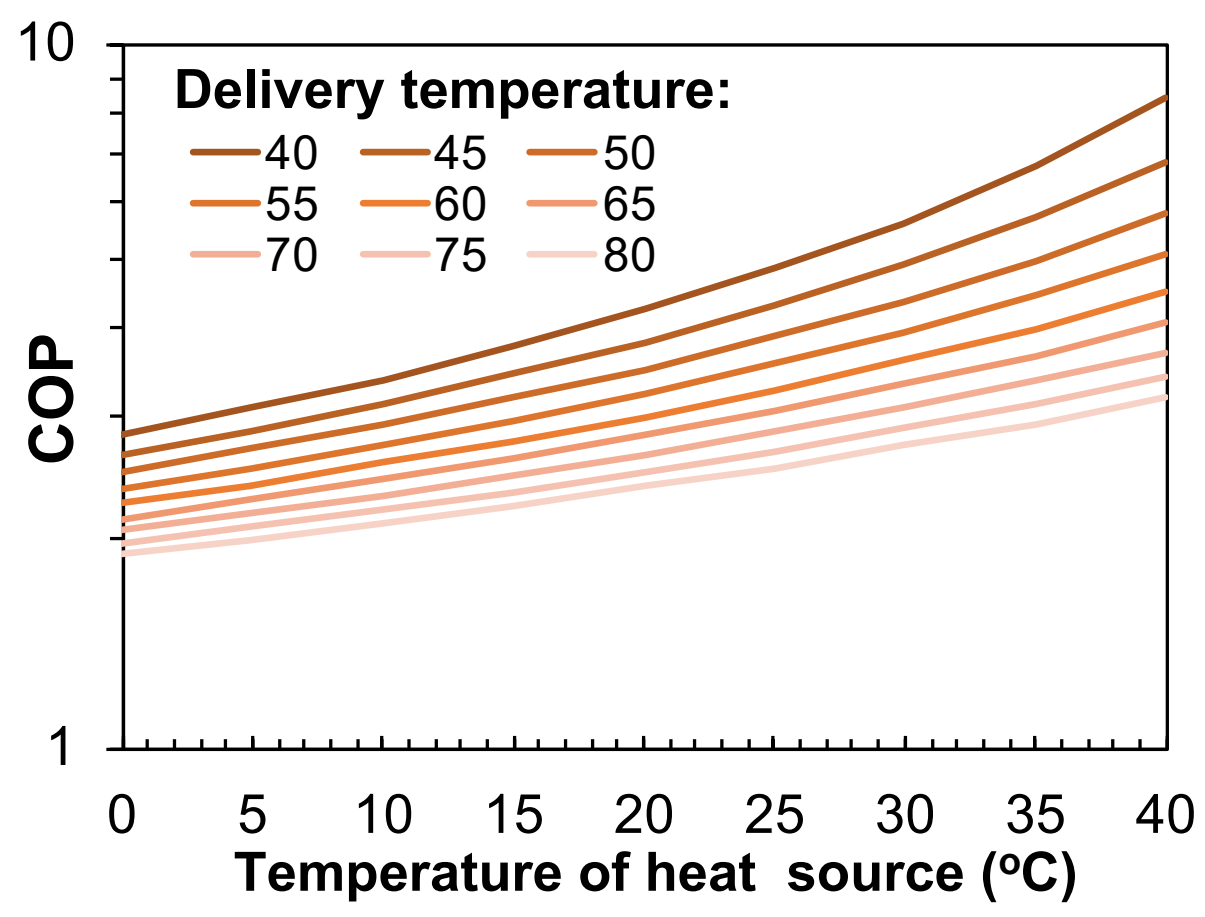

Figure 4. Example of COP for different heat source and delivery temperatures calculated with Eq. (3) $\left(\eta_{C A}=0.55, \eta_{m}=0.95, \Delta \mathrm{T}=10 \mathrm{~K}\right)$.

Assuming the same application with a heat pump, e.g. house heating $\left(\mathrm{T}=65^{\circ} \mathrm{C}\right)$, a deep-well heat source studied in this work $\left(\mathrm{T}=20-40{ }^{\circ} \mathrm{C}\right)$ could theoretically yield a $50-100 \%$ higher COP compared to a traditional heat source $\left(\mathrm{T}=5-10^{\circ} \mathrm{C}\right)$ based on Eq. (3).

Other figures of merit used for ground heat pumps, include the SCOP, or Seasonal Coefficient of Performance, which describes the average COP during a heating season. The SPF, or Seasonal Performance Factor, describes the average performance of a heat pump system during a defined period in a real application. SPF also takes into account the system performance e.g. all electricity consumption of the auxiliary equipment of the heat pump. Typically, the SPF would be lower than the COP. In Finland, the typical SPF value of a geothermal heat pump is 2.5 - 3.5 (Juvonen et al, 2013).

In a deep-heat system, the pumping energy needed to circulate the fluid in the borehole adds to the 'parasitic' losses, which will affect the SPF of the energy system. These losses can be estimated from pressure losses in the borehole as follows (White, 2008):

$$
\Delta p=f_{D} * \frac{L}{d_{h}} * \frac{\rho * u^{2}}{2}
$$




$$
Q_{p u m p}=\frac{\Delta p * \dot{m}}{\rho * \eta / 100}
$$

where $d_{h}=$ hydraulic diameter $(\mathrm{m}), f_{D}=$ friction factor, $L=$ pipe length $(\mathrm{m}), \dot{m}=$ mass flow rate $(\mathrm{kg} / \mathrm{s}), \Delta p=$ pressure drop $(\mathrm{Pa}), u=$ fluid velocity $(\mathrm{m} / \mathrm{s}), \eta=$ pump efficiency, $Q_{\text {pump }}=$ pumping power $(\mathrm{W})$. The electric power rate of the pump is obtained from manufacturers' data sheets.

Then the SPF or the system COP can be obtained by modifying Eq. (1):

$$
C O P_{\text {system }}=\frac{Q_{\text {evap }}+Q_{\text {comp }}}{Q_{\text {comp }}+Q_{\text {pump }}}=C O P_{H P} \times \frac{Q_{\text {comp }}}{Q_{\text {comp }}+Q_{\text {pump }}}=\frac{\operatorname{COP}_{H P}}{1+\frac{Q_{\text {pump }}}{Q_{\text {comp }}}}
$$

Therefore from Eq. (6), the ratio of the pumping to compressor power (or electricity) is crucial for the system COP of the bore-hole heat pump system. For example, with a $2 \mathrm{~km}$ deep well used in this study, performance values could be crudely $Q_{\text {evap }}=120 \mathrm{~kW}$ and COP $=3$, yielding $Q_{\text {comp }}=60 \mathrm{~kW}$. The pump size could be $Q_{\text {pump }}=5 \mathrm{~kW}$ (Grundfos, 2019), yielding a pump to compressor power ratio of 0.083 , which means that the system COP is $8 \%$ lower than the heat pump COP.

The hydraulic coupling of the heat pump to the heat source is done through the circulation network, in which the heat transfer medium will warm up and will be fed to the evaporator. The thermal power of the heat pump system $(\Phi)$ is therefore directly proportional to the temperature change in the heat transfer medium, or

$$
\Phi=\dot{m} c_{p}\left(T_{\text {out }}-T_{\text {in }}\right)
$$

where $\dot{m}=$ mass flow rate $(\mathrm{kg} / \mathrm{s})$, and $c_{p}=$ specific heat capacity of the heat transfer medium $(\mathrm{kJ} / \mathrm{kg} \mathrm{K})$. A typical value for the mass flow rate in a single ground heat pump pipe is 0.6 $\mathrm{kg} / \mathrm{s}$ and with a $c_{\mathrm{p}}=4 \mathrm{~kJ} / \mathrm{kg} \mathrm{K}$ and $\Delta \mathrm{T}=3 \mathrm{~K}$, this gives a thermal power of $7.2 \mathrm{~kW}$ (Juvonen, 2009).

A lower condensing temperature will improve the COP of the heat pump. The best COP would be achieved with a low-temperature heating systems such as floor heating in which the forward temperature typically is $28-40{ }^{\circ} \mathrm{C}$ compared to traditional radiator heating with $35-60{ }^{\circ} \mathrm{C}$. The difference in the COP could in this case be up to $40 \%$.

\subsection{Heat sources and heat collection systems}

The heat source forms an essential part of the heat pump system, also affecting its performance as explained earlier. The most common sources of heat in ground heat pump systems are soil, water bodies, and bedrock; it should though be noted that air is also a commonly used heat source, but not considered here. The heat from the earth is collected with a heat- 
collecting loop or circuit. It is a sub-surface piping network system in which a circulating a fluid inside the pipes is heated up by the surrounding ground. The circulation system is driven by a pump, which pumps up the heated heat transfer fluid to the heat pump (evaporator) and returns the cooled fluid back to the piping network

Figure 5 illustrates the different types of heat collection systems in use. The circulating systems used are divided into closed or open systems. In an open collection circuit, the heat transfer medium is part of the environment, for example water, which is circulated in the pipeline. The deep-well system, which is the focus of this thesis, is a typical open system. In a closed system, the heat transfer liquid is not connected to the environment. In this case, if a non-freezing liquid is used, usually a $25-30 \%$ alcohol mixture with water, circulating temperatures below $0{ }^{\circ} \mathrm{C}$ were possible enabling a more effective extraction of heat.

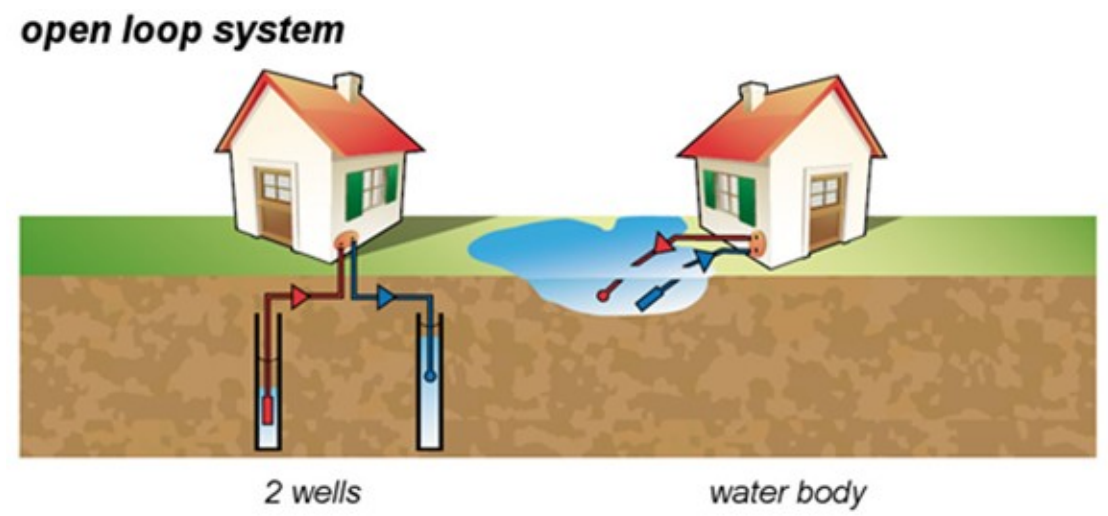

closed loop system

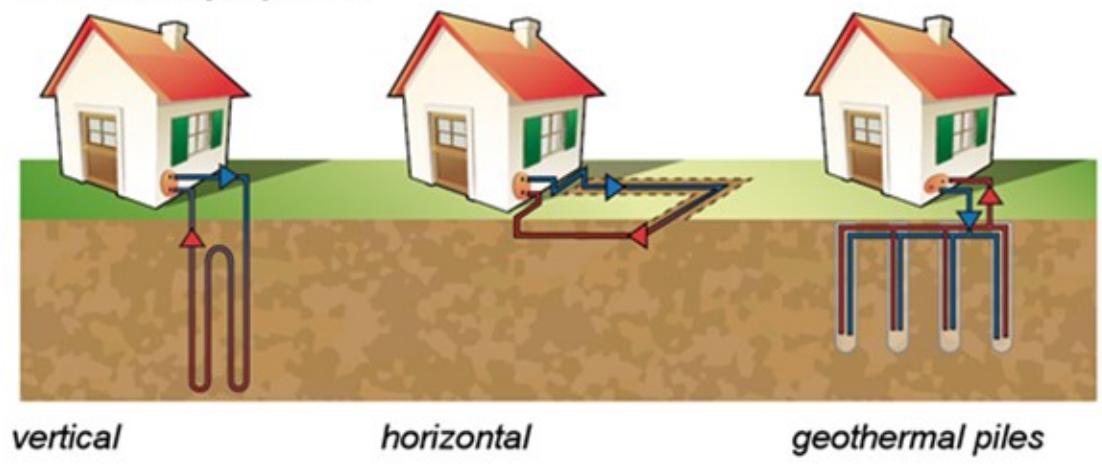

Figure 5. Heat collection systems for heat pumps (Ingrams Water and Air Equipment, 2019).

The heat collecting circuit can be installed either horizontally, immersed in the water, or embedded into the hole drilled in the rock. A horizontal pipeline system is installed near the ground to a depth of a few meters. It consists of one or several pipes connected in parallel or in series with a total length of at least 400-500 meters per single-family house in Finnish conditions. The pipe material is usually polyethylene. The land area required is about $1.5 \mathrm{~m}^{2}$ per meter of pipe. The need for surface area depends on the quality of the soil. In dry soil the surface area requirement may be significantly higher than in moist soil such as clay. The heat delivery capacity of this system type is around $10-15 \mathrm{~W} / \mathrm{m}$ of pipe and the ground temperature may vary from $<0{ }^{\circ} \mathrm{C}$ to above $15^{\circ} \mathrm{C}$. The soil is regenerated in the summer by the heating effect of the sun (Glassley, 2010; Juvonen \& Lapinlampi, 2013; Cervera, 2013). 
Aquatic sources can also be used as heat sources, for example lakes, ponds and seashores. The water depth should be at least $2 \mathrm{~m}$ and close to the shore to prevent damage to the pipelines in the winter time. Also, the pipes need to be anchored in the bottom with $5-10 \mathrm{~kg}$ concrete weights per $\mathrm{m}$ of pipeline. The piping itself would be similar to that in earth-coupled systems. Aquatic system could typically deliver heat $70-80 \mathrm{kWh} / \mathrm{m}$ per year (Ketonen, 2012; Kilpijärvi, 2015).

A common heat source used in Finland is the bed-rock. In this case a bore-hole of 100-300 $\mathrm{m}$ depth is drilled into the rock (Kukkonen,1985). The temperature of the ground at $200 \mathrm{~m}$ may exceed $10^{\circ} \mathrm{C}$ (Acuna, 2010), which is almost double that of the average temperature of upper ground layers. To cover the heat demand to be supplied, holes or energy wells are drilled at intervals of 10-20 meters so that they form an energy well field. For example, the Väre-building in Espoo-Otaniemi employs over 60 energy wells (Peura, 2017) in its heat pump systems.

Two main types of heat collection systems, or so-called collectors, can be used in boreholes to extract or inject heat (Figures 6 and 7): U-tubes made of polyethylene in which a mixture of water and anti-freeze solution (e.g. alcohol) is circulated, or a coaxial tube, which constitutes of an inner tube through which water is pumped from the bottom of the hole and water is injected up along the perimeter of the hole being heated at the same time. The borehole can be filled either with water or grout. A single borehole may deliver heat of around 100 $\mathrm{kWh} / \mathrm{a}$ per $\mathrm{m}$ (Aittomäki, 2012; Puranen 2016). The most common system used in Northern Europe for commercial use is a vertical closed U-pipe energy well system (Sanner et al., 2007). Future directions of the boreholes include the deep-well technology, in which the depth of the holes may extend to $1-3 \mathrm{~km}$. This technology will be discussed more in detail in Section 4.
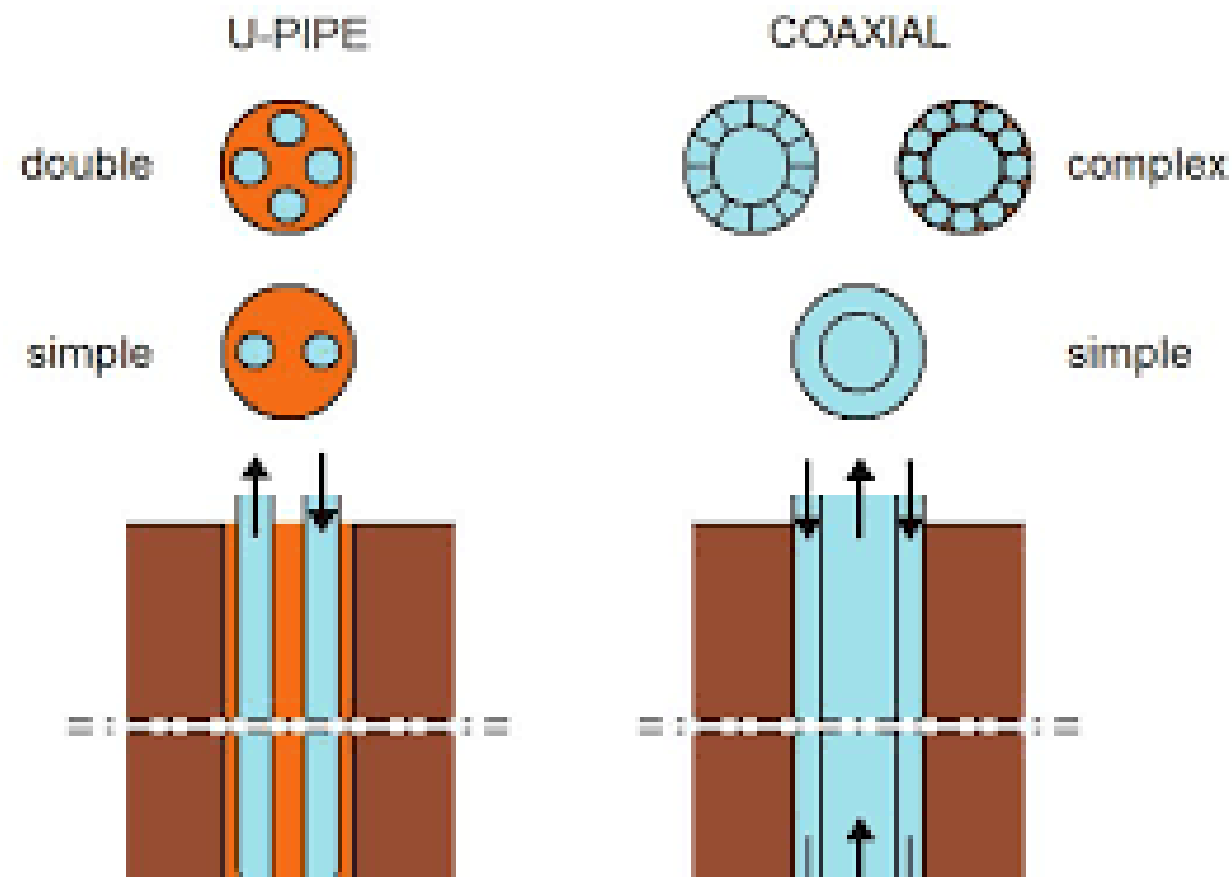

Figure 6. Schematics of U-pipe and coaxial-pipe heat exchanger (Scorpo, 2013). 


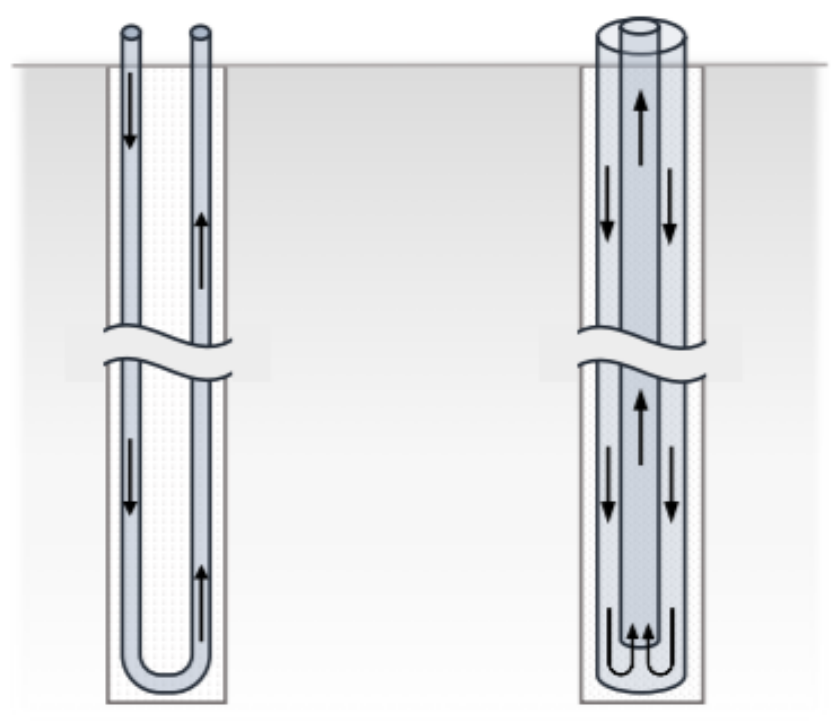

Figure 7. U-tube collector (left) and coaxial collector (right) (Rindahl, 2016).

Comparing horizontal and vertical heat extraction systems, it is typically cheaper to install a horizontal heat collector in ground than a vertical heat well if the excavation depth is $1-2 \mathrm{~m}$ or less than $10 \mathrm{~m}$. For deeper depths, drilling becomes cheaper, but it also avoids extensive excavation. 


\section{Deep-heat energy wells}

The basic difference between a traditional vertical and deep-heat energy well is the depth of the borehole, which extends to 1-3 kilometers enabling much higher delivery temperature due to increasing rock temperature from the geothermal heat gradient.

The main advantages of deeper holes relate to the higher heating effect per length and higher temperature (the geothermal gradient in Scandinavia is $10-30{ }^{\circ} \mathrm{C} / \mathrm{km}$ ), which reduces the number of holes needed to deliver the same heat effect. The lesser surface area required is beneficial when using ground-coupled heat pump systems in urban areas. The deep wells also enable to store heat in the ground e.g. to regenerate the heat source, or to provide cooling in the summertime. A deeper heat extraction depth may also minimize possible disturbances to ecosystems (Gehlin et al., 2016).

Deep-heat wells raise new challenges such as increased heat exchange between forward and return flows in the borehole pipe (so-called thermal short-circuiting). Also, the traditional heat collection and circulation pipe system may not fully be applicable in this case, e.g. proper control strategies for such systems need to be developed. Plastic U-tubes may not be suitable and instead coaxial tubes designed for this purpose will be necessary. For this reason, water must be used as heat transfer fluid, which limits the minimum temperature to $>0$ ${ }^{\circ} \mathrm{C}$ (Rindahl, 2016).

In the next, the deep-heat energy well technology is reviewed in more detail.

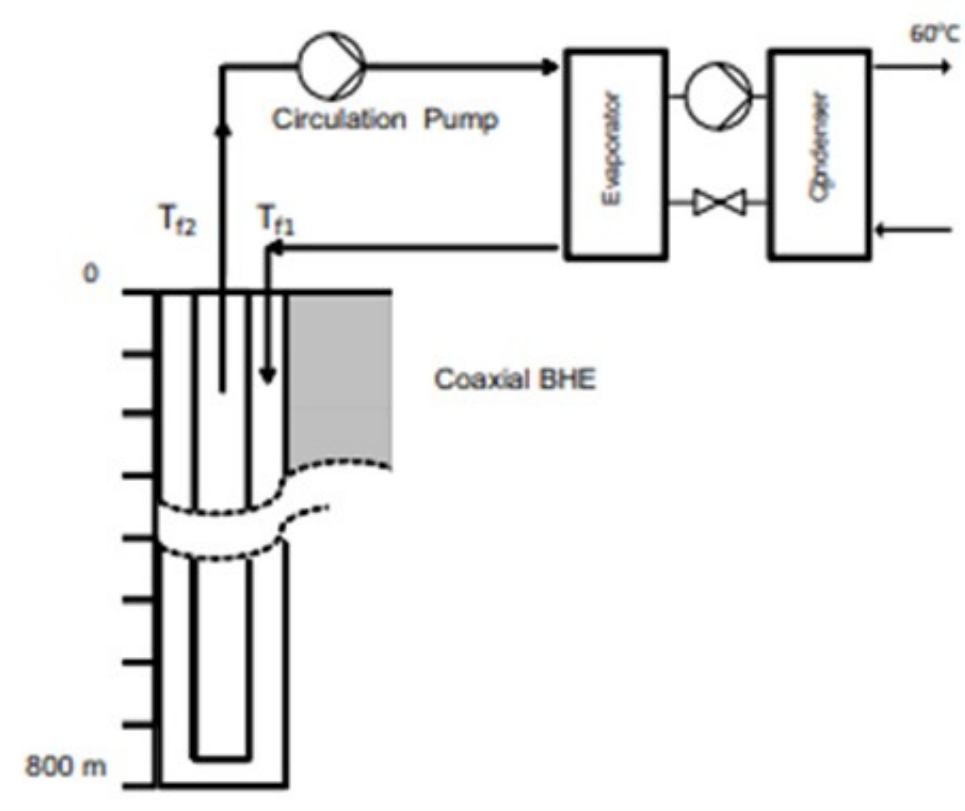

Figure 8. Illustration of a deep-heat energy well system (Holmberg et al., 2016). 


\subsection{Previous work}

Most of the experience on deep-heat boreholes is outside northern Europe. Technically, employing e.g. abandoned oil or natural gas wells to rebuilt these into a heat exchanger could be possible, but this has often turned out to be too complex for which reason virgin borehole heat exchangers seems to be the main solution for utilizing geothermal heat (Sliwa et al., 2015). As early as 1995, Rybach and Hopkins (1995) investigated deep boreholes for geothermal energy in Switzerland. Two deep boreholes of $1700 \mathrm{~m}$ and $2300 \mathrm{~m}$ depth were linked to heating of buildings. They observed that not only the size and closeness of the energy to the user, but also the temperature at which heat is to be delivered affects to the economics of the deep well. Kohl (2002) studied a $1200 \mathrm{~m}$ deep borehole originally drilled in the late 1990 s, and tried to verify the use of water filled fracture for deep geothermal heat extraction, though not being successful. More recently, deeper holes have been studied by Huchtemann and Müller (2014) and Dijshoon et al. (2013), which has involved $2500 \mathrm{~m}$ coaxial wells for heating and cooling in Aachen, Germany. In 2015, 150 wells of $750 \mathrm{~m}$ depth with U-tubes were drilled in Lausanne, Switzerland to serve a residential and commercial area (Gehlin et al., 2016).

The experience on deep wells in the Nordic countries is very limited. Shallow geothermal energy wells, such as vertical wells, dominate the borehole markets for heat pump systems. The depth of boreholes has increased over the years now typically being in the range of 100 $300 \mathrm{~m}$ (Figure 9). Main past experience is from Norway, where a school was heated by five $500 \mathrm{~m}$ deep boreholes with U-tubes in 2013. In Asker, Norway, nine $500 \mathrm{~m}$ deep boreholes were drilled to heat a building. Rindahl (2016) studied a pilot project also at Asker, where two 800 meter deep coaxial hole were drilled. Holmberg et al. (2015) have done numerical simulations on 600-1000 m deep coaxial heat exchangers for northern European conditions.

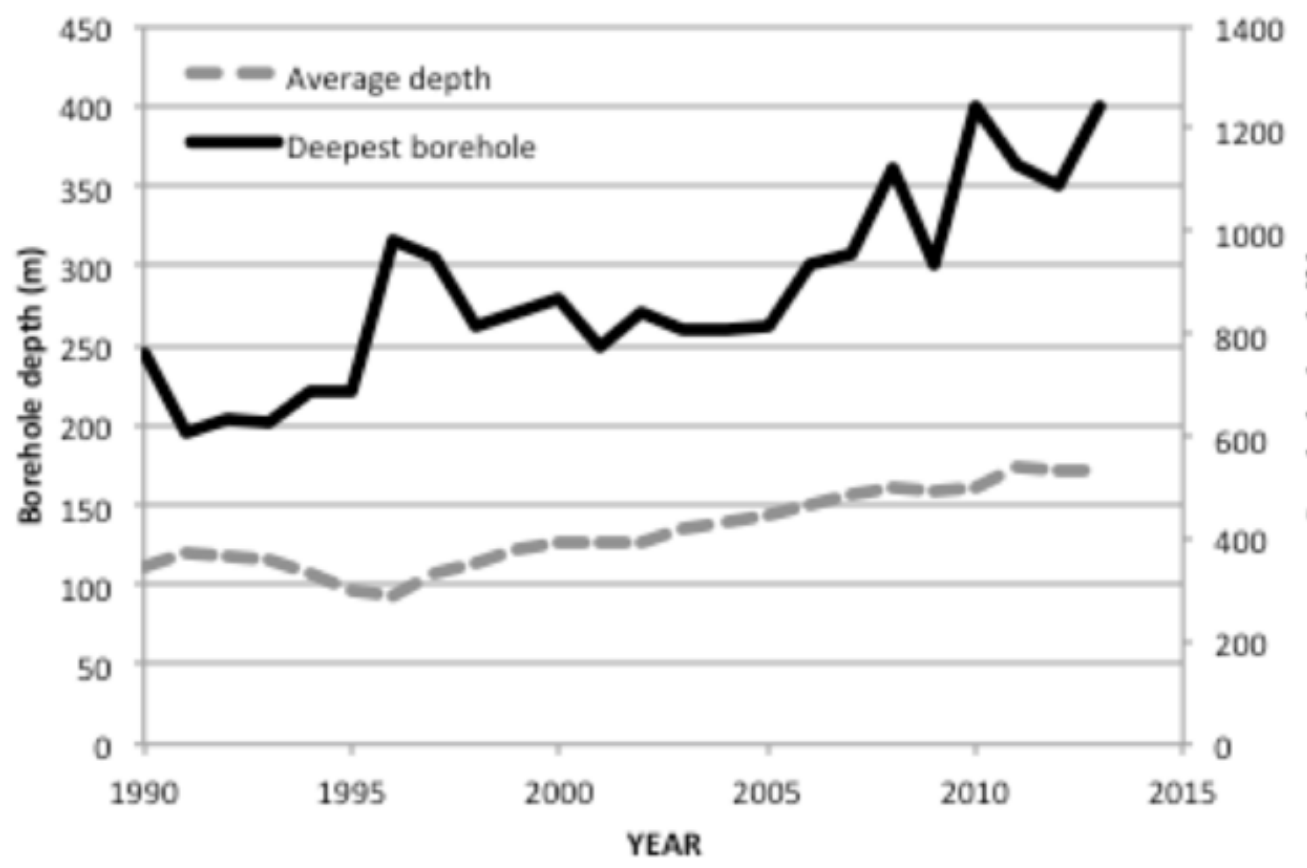

Figure 9. Average borehole depth and deepest borehole in Sweden (Gierup, 2015). 


\subsection{Technology comparison}

Two basic approaches for the borehole heat exchanger (BHE) could be used for a deep-well case, namely U-tube collector or coaxial pipes. Often existing BHEs employ U-tubes, but simple extrapolation to the deep-well case would not come without problems. Namely, with increasing depth the heat carrier flow rate need to be increased to effectively extract the heat from the borehole and to avoid thermal shunting of the forward and return flows. At the same time, pressure losses in the U-tube would increase, which would require increasing the diameter of the pipe. Compared to the U-tube, the borehole with a coaxial pipe uses a larger portion of the cross-sectional area of the borehole as the flow area, and hence it fits better higher mass flow rates. Figure 10 shows the pressure drop of a borehole of U-shape and a coaxial pipe for different flow rates (Acuna, 2010). At high flow rates, the difference is almost 3-fold.

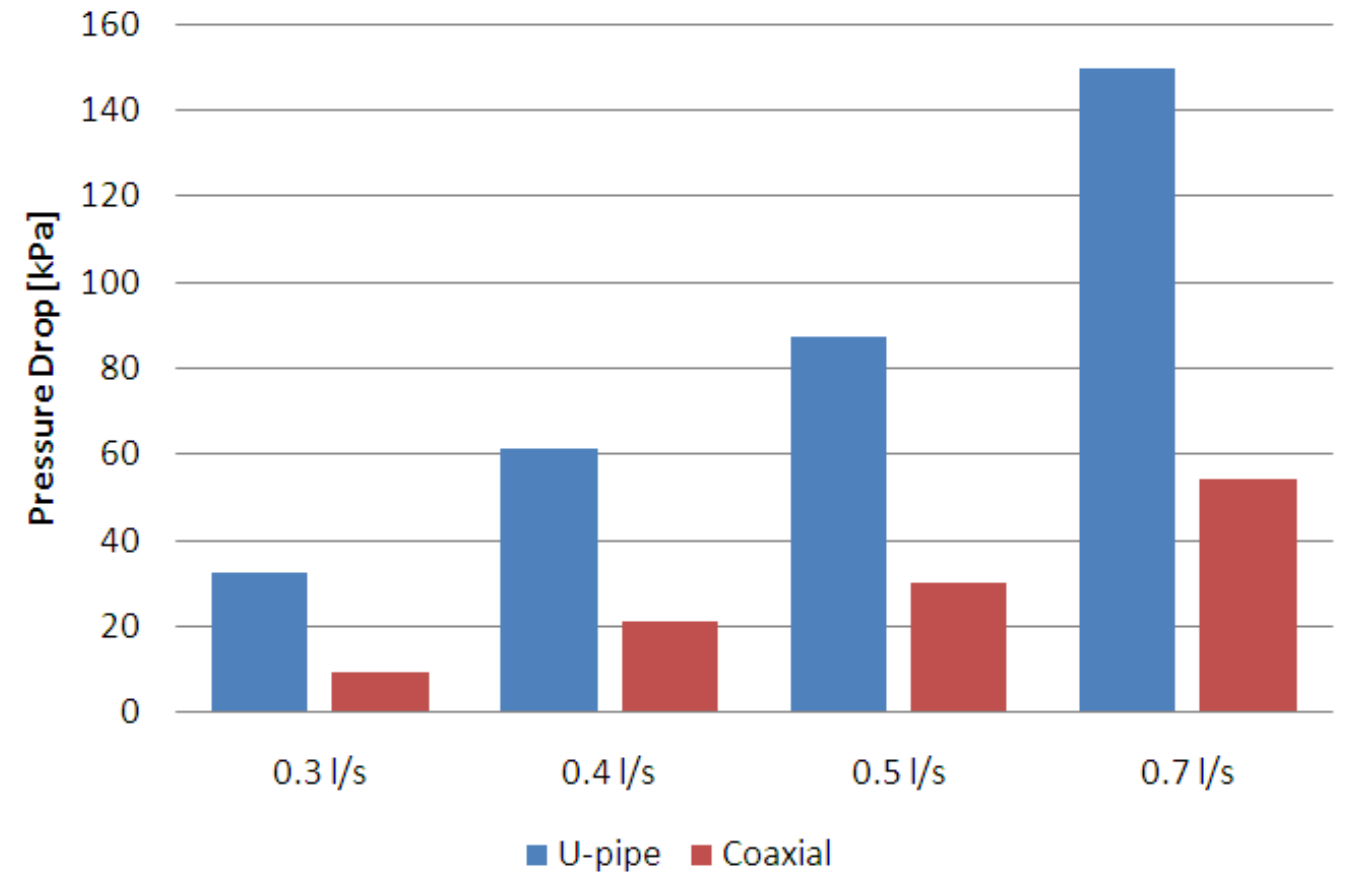

Figure 10. Pressure drop in coaxial and U-pipe BHE (Acuna, 2010).

Another benefit of a coaxial borehole is that it could reduce the internal thermal resistance in the borehole heat exchanger and increase the temperature of the heat carrier fluid, which improves the performance of the heat pump system. The internal resistance has two components: the resistance through the collector material and the resistance of the medium surrounding the collector, respectively. The coaxial design has a lower resistance than the Upipe (Kjellson and Hellström, 1999; Acuna, 2013). A long U-pipe may also become shortcircuited. Inside the borehole, natural convection in water may also enhance the heat transfer, but quantitative details on the phenomenon are still lacking, e.g. BHE-models do not account for the effects from natural convection. If the BHE is also used for thermal storage, this site should not have high groundwater flow at reservoir depth as this would cause additional losses. However, in case of using ground as a heat source only, this could be beneficial (Homuth et al., 2016). 
The heat effect delivered by a vertical energy-well is determined by the surrounding ground temperature, heat conductivity of ground, thermal gradient in the vicinity of the borehole, and the temperature of the circulating fluid (Aittomäki, 2008). Figure 11 shows the heat delivery capacity of the well as a function of borehole depth and the geothermal gradient (GG); the borehole diameter is $140 \mathrm{~mm}$. Doubling the borehole depth from $300 \mathrm{~m}$ to $600 \mathrm{~m}$ increases the thermal effect by 3.5 times, a further increase to $900 \mathrm{~m}$ borehole depth results in an increase of almost 8 times (Holmberg et al., 2016).

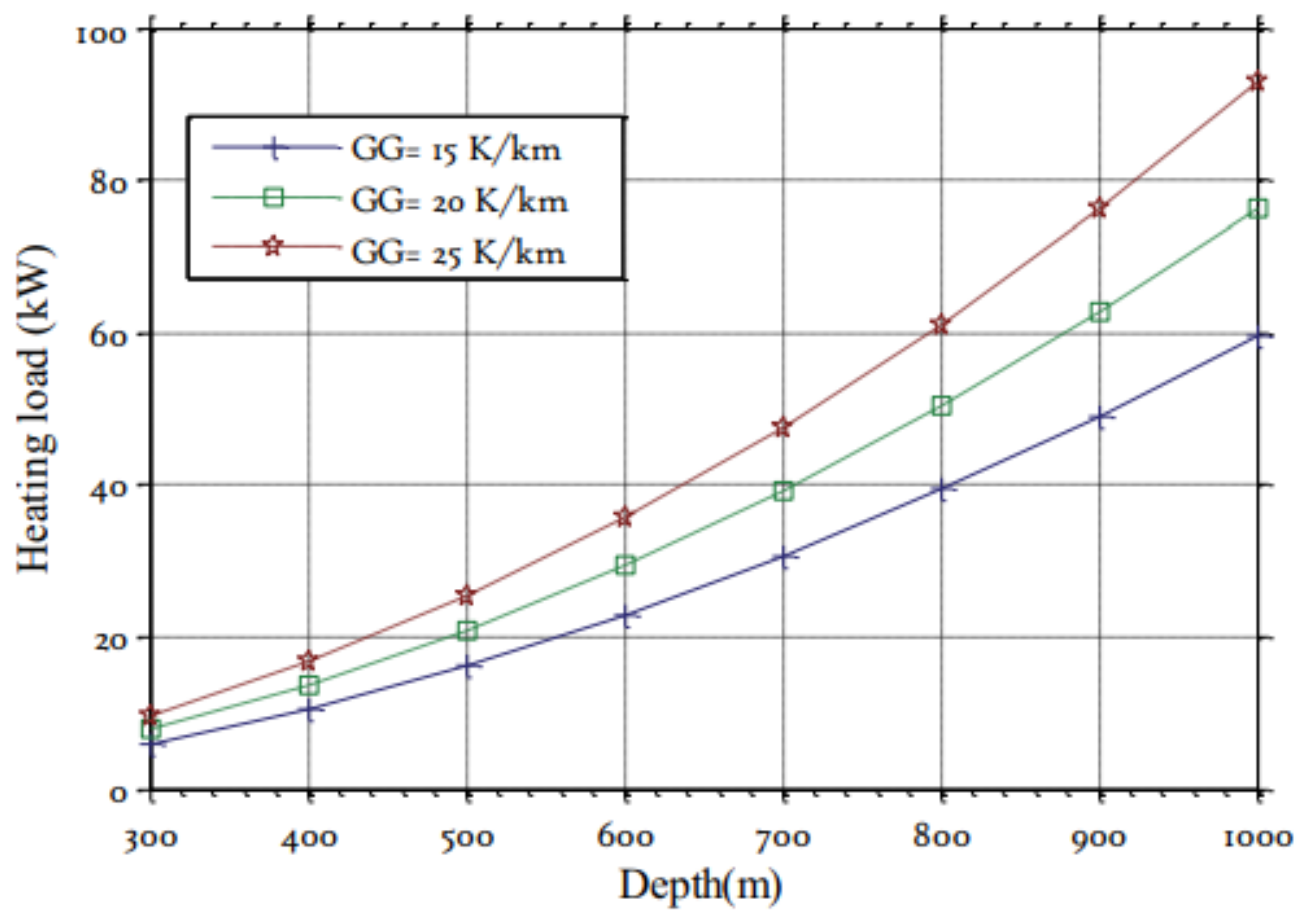

Figure 11. Heat load as function of depth and geothermal gradient, simulation time is 5000 h, $\mathrm{d}_{0}=140 \mathrm{~mm}$ (Holmberg et al., 2016).

The pressure drop in the BHE depends both on the diameter and length of the BHE, and the flow velocity. Figure 12 illustrates the pressure drop in a coaxial pipe. For comparison, the pressure drop of a single $40 \times 2.4 \mathrm{~mm}$ U-tube collector in a $300 \mathrm{~m}$ borehole is about $1.2 \mathrm{bar}$, i.e. much higher than in a coaxial pipe. Another aspect of interest is the required pumping energy versus BHE diameter and length. It seems that beyond $0.5 \mathrm{~km}$ deep holes, the power requirement for fluid circulation starts to grow, meaning that wider pipes would be beneficial to avoid a decrease in the effective COP of the heat pump system (Holmberg et al., 2016). 


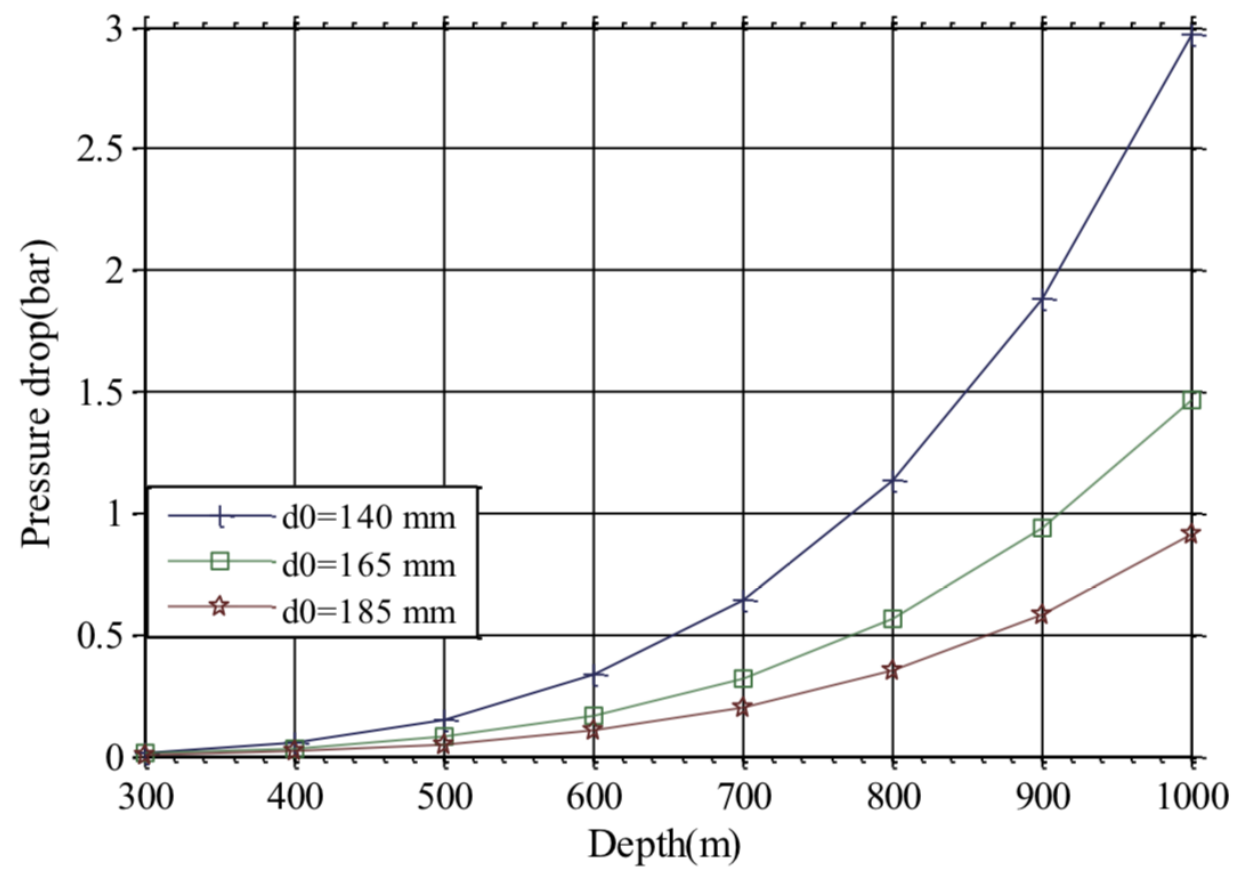

Figure 12. Pressure drop as a function of borehole depth and diameter. Simulation time is $5000 \mathrm{~h}, \mathrm{GG}=20 \mathrm{~K} / \mathrm{km}$. (Holmberg et al., 2016)

Summarizing, a coaxial BHE seems more suitable for deep heat extraction and is chosen in this work for the reference technology option. As an example of the potential or the deep coaxial BHE is that a single $800 \mathrm{~m}$ borehole could provide more heat than 6 conventional $300 \mathrm{~m}$ U-pipes.

\subsection{Coaxial pipe}

The basic structure of a coaxial pipe was shown in Figure 6. The technology has been demonstrated in several projects (Sanner et al., 2007). A coaxial pipe consist of a pipe in a pipe, i.e. a cylindrical center pipe and an annular external cannula that is in almost direct contact with the borehole wall.

There are different designs for the coaxial BHE, e.g. how the inner and outer pipes are designed. For example, the inner pipe, which is often made of polypropylene, could be isolated to reduce the heat transfer between the flows, which is important at high flow rates.

In deep heat systems, coaxial BHEs with a steel center pipes and vacuum insulated central pipe have been employed (Sliwa, 2017). An insulated central pipe clearly improves the performance. Vacuum Insulated Tubing (VIT) technology is an interesting option for deep wells. It consists of two coaxial steel pipes with a vacuum in between, which reduces the heat transfer between the inner tube and the wall. The thermal conductivity could be dropped down to $0.006-0.0008 \mathrm{~W} / \mathrm{m} \mathrm{K}$, compared to conventional steel tubes with $40 \mathrm{~W} / \mathrm{m} \mathrm{K}$. (Silwa et al., 2018; Morita, 2001) 
In the so-called Thermal Insulated Leg design, a borehole consisting of one insulated inner tube and a few outer tubes is employed. Another similar design consisted of one central channel and five outer channels with trapezoidal cross section. Thermal analysis of laboratory tests with such arrangements indicated that thermal resistances between 0.009 to 0.028 $\mathrm{K} \mathrm{m} / \mathrm{W}$ could be reached (Hellström et al., 2000). More recent results show that thermal resistances of 0.02 to $0.03 \mathrm{~K} \mathrm{~m} / \mathrm{W}$ could be feasible in practical projects.

A coaxial borehole exchanger can be constructed as an open loop, where the fluid (water) is in direct contact with the rock. An alternative is a closed system with a secondary heat carrier fluid. The benefits of a closed, or a near closed system, is that contamination of the fluid can be avoided which could cause fouling of the heat exchangers. Using water as the fluid in the borehole requires a somewhat higher operation temperature to avoid freezing during peak load. A closed loop can be used either with water or with an antifreeze solution. However, for deeper boreholes significant volumes of fluid would be needed. But as the temperature in the borehole increases with depth thanks to the geothermal temperature gradient, the role of the antifreeze solution decreases.

\subsection{Operation of a deep borehole exchanger}

The purpose of the borehole is to provide a stable and high enough temperature for the heat pump. For stable operation it is important that the deep well is in balance, i.e. the same amount of energy is transferred to the well than is extracted over the year. In a negatively balanced system, the ground around the hole cools and the heat from the hole will not be

sufficient to supply adequately heat over time, which drops the efficiency of the ground source heat pump.

Such a situation can be avoided by charging the well with excess heat during the summer, or alternatively by using solar heat. In this case the ground also operates as a long-term heat storage. Another option is to lower the heat extraction rate (Holmberg, 2016).

The function of a deep well can be divided into two parts: extracting and injecting heat. In heat extraction mode, cold water is fed into the borehole to collect heat from the surrounding rock. In heat injection, hot water is injected to the borehole heat exchanger to charge up the reservoir.

The flow direction during injection need to be reversed, which affects the thermal performance of the coaxial borehole, because the direction of flow and the inlet temperature influence the heat transfer between the fluid and rock. Therefore, the flow conditions may need to be adjusted separately in both cases.

A discharging/charging strategy is illustrated in Figure 13. When charging, the fluid should reach the bottom in a insulated inner pipe before the heat is discharged into the surrounding rock at maximum depth (Bär, 2015). In the extraction case, the cold fluid is injected into the outer pipe to utilize the borehole wall as a heat exchanger. The heat losses of the working fluid is minimized by circulating it back to the surface through the insulated central pipe.

Detailed analysis of the effects of the flow directions in BHE indicate that a borehole has potential for cooling in the range of $500 \mathrm{~m}$. However, for deeper boreholes, the lower part 
of the borehole becomes poorly utilized for cooling. Therefore, deeper boreholes are most suitable for heat extraction.

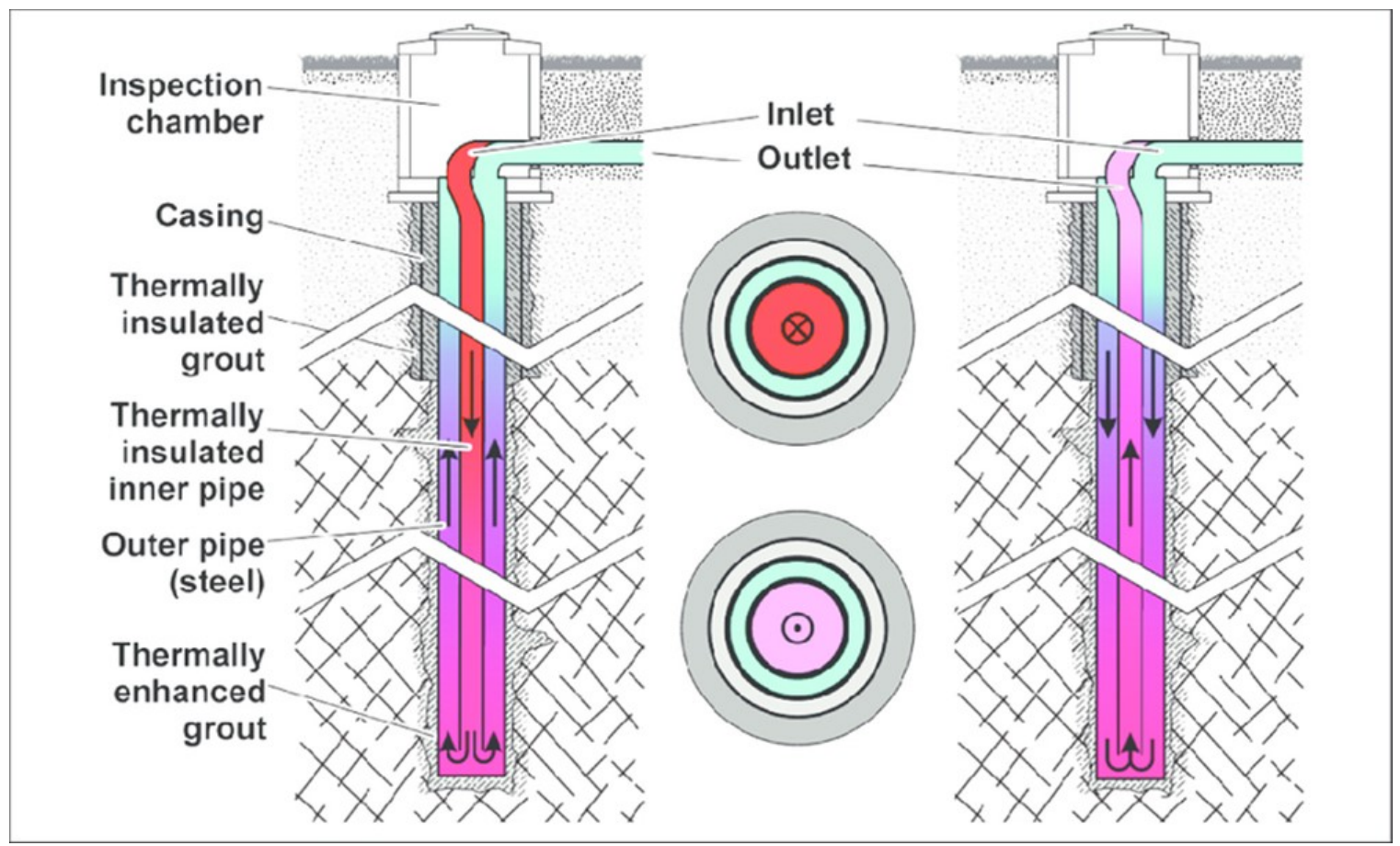

Figure 13. Illustration of a deep coaxial borehole heat exchanger in bedrock. The borehole is used as a heat storage in the summer (charging mode, left side) and it is discharged in the winter (discharging mode, right side) (Homuth et al., 2015). 


\section{Heat transfer in deep borehole exchangers}

In this section, the governing equations of heat transfer in a deep borehole heat exchanger is presented. These equations form the basis for the simulations of the borehole performance, which is done with the COMSOL Multiphysics software (COMSOL, 2019). Because of the long time constants, wide spatial impact, and complex engineering, modelling is often the only way to study the effects of parameter variations or to do optimization.

The heat transfer in a borehole has intensively been modelled in the past. Models used include heat conduction analysis, closed-form analytical models, superposition models, numerical models, etc. (Hellström, 1998; Carslaw et al., 1959; Lund et al., 1985). The heat transfer phenomena in the studies mentioned above are often the same, but the accuracy of modelling or approximations used vary.

The basic heat transfer processes in a coaxial borehole include convection-dominated heat transfer in the pipes (fluid), heat transfer at pipe-rock interface (fluid-solid), and heat conduction in bed-rock (solid). In the pipe walls, heat is transported by conduction. These processes are also modelled in this work. In addition, if the bedrock is fractured or porous, natural convection may also occur in the solid due to buoyant forces, requiring then also including a fluid flow analysis, but this is not considered in this work. Heat transfer is also affected by the thermal properties, which are assumed here constant as the temperature (and pressure) regime considered is quite narrow $\left(0-60^{\circ} \mathrm{C}\right)$ and no phase change will either occur.

In the next, the individual heat transport components are described.

\subsection{Heat transfer in solid}

A generalized transport equation for heat can be derived outgoing from the Fourier's Law combined with the First and Second Laws of Thermodynamics (Incropera et al., 2007):

$\rho \frac{\partial E}{\partial t}+\rho u \cdot \nabla E+\nabla \cdot\left(q_{c}+q_{r}\right)=\sigma: D+Q^{\prime \prime}$

where

$\rho=$ density, $\mathrm{kg} \mathrm{m}^{-3}$

$D=$ strain rate tensor

$E=$ internal energy, $\mathrm{J}$

$Q^{\prime \prime}=$ volumetric heat source, $\mathrm{Wm}^{-3}$

$u=$ velocity field, $\mathrm{ms}^{-1}$

$q_{c}=$ heat flux by conduction, $\mathrm{Wm}^{-2}$

$q_{r}=$ heat flux by radiation, $\mathrm{Wm}^{-2}$

$\sigma=$ Cauchy stress tensor 
The equation describes how variations in internal energy in time are balanced by convection of internal energy, thermal conduction, radiation, dissipation of mechanical stress and additional volumetric heat sources.

Limiting to solids only, Eq.(8) can be simplified to

$$
\rho c_{p}\left(\frac{\partial T}{\partial t}+u_{\text {trans }} \cdot \nabla T\right)+\nabla \cdot\left(q_{c}+q_{r}\right)=-\alpha T: \frac{d S}{d T}+Q^{\prime \prime}
$$

where

$\rho=$ density, $\mathrm{kg} \mathrm{m}^{-3}$

$c_{p}=$ specific heat capacity at constant stress, $\mathrm{J} \mathrm{kg}^{-1} \mathrm{~K}^{-1}$

$T=$ temperature, $\mathrm{K}$

$u_{\text {trans }}=$ velocity vector of translational motion, $\mathrm{ms}^{-1}$

$q_{c}=$ heat flux by conduction, $\mathrm{Wm}^{-2}$

$q_{r}=$ heat flux by radiation, $\mathrm{Wm}^{-2}$

$\alpha=$ coefficient of thermal expansion, $\mathrm{K}^{-1}$

$S=$ second Piola-Kirchoff stress tensor, $\mathrm{Pa}$

$Q^{\prime \prime}=$ volumetric heat sources, $\mathrm{Wm}^{-3}$

Thermoelastic effects from thermal expansion are negligible $\alpha=0$. Also, $q_{r}=0$ (no radiation) and $u=0$ (no convection). Thus the heat conduction equation in a solid (bed-rock) is obtained as follows (denoting ground temperature with $\mathrm{T}_{\mathrm{g}}$ ):

$$
\rho c_{p} \frac{\partial T_{g}}{\partial t}+\nabla \cdot q_{c}=Q^{\prime \prime}
$$

The term $q_{c}$ represents heat conduction in the solid and is governed by the Fourier's law:

$$
q_{c}=-k_{g} \frac{\partial T_{g}}{\partial x}-k_{g} \frac{\partial T_{g}}{\partial y}-k_{g} \frac{\partial T_{g}}{\partial z}
$$

where $k_{g}=$ conductivity of ground $(\mathrm{W} / \mathrm{m} \mathrm{K})$.

Substituting $q_{c}$ in Eq. (10) with Eq. (11) yields for the final form of

$$
\rho c_{p} \frac{\partial T_{g}}{\partial t}=k_{g} \frac{\partial^{2} T_{g}}{\partial x^{2}}+k_{g} \frac{\partial^{2} T_{g}}{\partial y^{2}}+k_{g} \frac{\partial^{2} T_{g}}{\partial z^{2}}+Q^{\prime \prime}
$$

The term $Q$ ', on the right side of the Eq. (12) contains sources of heat, for example the heat from radioactive decay in the rock. 


\subsection{Heat transfer in pipe}

The heat transfer in the borehole pipe is treated here as one dimensional. It involves two components: Heat transfer in the pipe annulus and in the inner pipe. The fluid temperature $T_{f}$ in the pipe can be solved from the energy equation for an incompressible fluid flowing in a pipe (Lurie, 2008):

$$
\begin{aligned}
& \rho A c_{P} \frac{\partial T}{\partial t}+\rho A c_{P} u \cdot \nabla T_{f} \\
& =\nabla \cdot A k \nabla T+f_{D} \frac{\rho A}{2 d_{h}}|u|^{3}+Q^{\prime}+Q^{\prime}{ }_{\text {wall }}+Q^{\prime}{ }_{p}
\end{aligned}
$$

where

$$
\begin{aligned}
& A=\text { pipe cross section area avaible for flow, } \mathrm{m}^{2} \\
& c_{p}=\text { specific heat capacity at constant pressure, } \mathrm{J} \mathrm{kg}^{-1} \mathrm{~K}^{-1} \\
& f_{D}=\text { friction factor } \\
& u=\text { fluid velocity (vector), } \mathrm{ms}^{-1} \\
& T_{f}=\text { fluid temperature, } \mathrm{K} \\
& k=\text { thermal conductivity, } \mathrm{Wm}^{-1} \mathrm{~K}^{-1} \\
& \mathrm{~d}_{\mathrm{h}}=\text { hydraulic diameter, } \mathrm{m} \\
& Q^{\prime}=\text { general heat source, } \mathrm{Wm}^{-1} \\
& Q^{\prime}{ }_{\text {wall }}=\text { external heat exchange through pipe wall, } \mathrm{Wm}^{-1} \\
& \mathrm{Q}_{\mathrm{p}}^{\prime}=\text { pressure work, } \mathrm{Wm}^{-1} \\
& \alpha=\text { coefficient of thermal expansion, } \mathrm{K}^{-1} \\
& \rho=\text { fluid density, } \mathrm{kg} \mathrm{m}^{-3}
\end{aligned}
$$

In case the pressure drop were significant and the fluid were compressible, an additional term $Q^{\prime}{ }_{p}$ need to be added to the right side of Eq. (13):

$$
Q_{p}^{\prime}=-\frac{T A}{\rho} *\left(\frac{d \rho}{d T}\right)\left(\frac{d p}{d T}+u \cdot \nabla p\right)
$$

Friction is described through the friction coefficient $f_{D}$, for which the Churchill's approximation describing both laminar and turbulent regions is used (Churchill, 1975):

$$
f_{D}=8\left[\left(\frac{8}{\operatorname{Re}}\right)^{12}+\frac{1}{(A+B)^{\frac{3}{2}}}\right]^{\frac{1}{12}}
$$

where coefficients A and B are

$$
A=\left\{2.457 \cdot \ln \left[\frac{1}{\left(\frac{7}{\mathrm{Re}}\right)^{0,9}+\left(0.27 * \frac{\varepsilon}{d}\right)}\right]\right\}^{16}
$$




$$
B=\left(\frac{37530}{\operatorname{Re}}\right)^{16}
$$

Re is the Reynolds number based on the diameter of the pipe, $\varepsilon$ is the roughness of the inner surface of the pipe and $D$ is the diameter of the pipe.

The three remaining terms on the right side of Eq. (13) are the evolving power in the tube, power through the pipe delivered, and power associated to change in volume of active work. Only the wall heat output is important here and the other terms can be omitted. The external heat exchange $Q_{\text {wall }}$ through the pipe wall is described by radial heat transfer from the surroundings into the pipe, which thermally couples the ground and fluid :

$$
k_{g} Z \frac{\partial T_{g}}{\partial r}=(h Z)_{e f f}\left(T_{e x t}-T\right)=Q^{\prime}{ }_{\text {wall }}
$$

$$
\begin{aligned}
& \text { where } \\
& h=\text { heat transfer coefficient, } \mathrm{Wm}^{-2} \mathrm{~K}^{-1} \\
& k_{g}=\text { thermal conductivity of ground, } \mathrm{Wm}^{-1} \mathrm{~K}^{-1} \\
& Z=\text { wall perimeter area, } \mathrm{m}^{2} \\
& T_{\text {ext }}=\text { temperature outside wall of pipe , } \mathrm{K}
\end{aligned}
$$

The term $h$ is an effective value of the heat transfer coefficient. $h$ is calculated through the film resistances and wall layers and is defined as the following:

$$
h=\mathrm{Nu} \frac{\mathrm{k}_{\mathrm{p}}}{\mathrm{d}_{\mathrm{h}}}
$$

where

$\mathrm{Nu}=$ Nusselt number

$\mathrm{k}_{\mathrm{p}}=$ thermal conductivity of the material

$d_{h}=$ the hydraulic diameter $=4 A Z^{-1}$

The Nusselt number for internal laminar forced convection in fully developed pipe flow is a constant. It depends on the pipe cross-section and for circular its 3.66, while in internal turbulent convection $\left(3000<\operatorname{Re}<6 \cdot 10^{6}, 0.5<\operatorname{Pr}<2000\right)$, the Gnielinski equation (Gnielinski, 1976) applies:

$$
\mathrm{Nu}=\frac{\left(\frac{f_{D}}{8}\right)(\mathrm{Re}-1000) \operatorname{Pr}}{1+12.7\left(\frac{f_{D}}{8}\right)^{\frac{1}{2}}\left(\operatorname{Pr}^{\frac{2}{3}}-1\right)}
$$

Pr is the Prandtl number. The Prandtl number describes the momentum and heat energy ratio of diffusivities in fluid. It is defined as (Incropera et al., 2007): 


$$
\operatorname{Pr}=\frac{C_{p} \mu}{k_{L}}
$$

The Nusselt number for external forced convection around a pipe, valid for all Re and for $\operatorname{Pr}>0.2$, is defined though the Churchill and Bernstein (Churchill et al., 1977) correlation:

$$
\mathrm{Nu}=0.3+\frac{0.62 \mathrm{Re}^{\frac{1}{2}} \operatorname{Pr}^{\frac{1}{3}}}{\left[1+(0.4 / \mathrm{Pr})^{\frac{2}{3}}\right]^{\frac{1}{4}}}\left[1+\left(\frac{\mathrm{Re}}{282000}\right)^{\frac{5}{8}}\right]^{\frac{4}{5}}
$$

For external natural convection around a pipe, the Churchill and Chu (Churchill et al., 1975) correlation can be used for $\mathrm{Ra}<10^{12}$ :

$$
\mathrm{Nu}=\left\{0.60+\frac{0.387 \mathrm{Ra}^{\frac{1}{6}}}{\left[1+\left(\frac{0.559}{\mathrm{Pr}}\right)^{\frac{9}{16}}\right]^{\frac{8}{27}}}\right\}^{2}
$$

$\mathrm{Ra}$ is the Rayleigh number and it is defined as (Incropera et al., 2007)

$$
\mathrm{Ra}=\operatorname{PrGr}
$$

Gr is the Grashof number and it is defined as (Incropera et al., 2007; Moran, 2014)

$$
\mathrm{Gr}=\frac{g \beta\left|T_{N}-T_{\text {ext }}\right| d^{3}}{\left(\frac{\mu}{\rho}\right)^{2}}
$$

where $d$ is the outside diameter of the pipe and $\beta$ is the coefficient of volumetric expansion:

$$
\beta=-\frac{1}{\rho}\left(\frac{\partial \rho}{\partial T}\right)
$$

The overall heat transfer coefficient including internal film resistance, wall resistance, and external film resistance can finally be deduced as follows for circular pipe cross-sections (COMSOL, 2019): 


$$
(h Z)_{e f f}=\frac{2 \pi}{\frac{1}{r_{0} h_{i n t}}+\frac{1}{r_{N} h_{e x t}}+\sum_{n=1}^{N}\left(\frac{\ln \frac{r_{n}}{r_{n-1}}}{k_{n}}\right)}
$$

The $h_{\text {int }}$ and $h_{\text {ext }}$ are the film heat transfer coefficients on the inside and outside of the tube, respectively. They can be calculated from Eq. (19); $r_{n}$ is the outer radius of wall, $k_{n}$ is the thermal conductivity of wall $\mathrm{n}$.

\subsection{Natural flows}

As the deep-heat well system includes major temperature differences and spans over a long distance, the question of temperature-induced buoyant flows and ground water flow deserves consideration. Convective flows in bedrock, in which heat is transferred through mass flow, is theoretically possible if the rock contains water and suitable pathways for flow, e.g. porous media or fissures (Bear, 1988). In addition, a driving force, i.e. pressure difference, is needed to move the water, which could be caused by a hydraulic gradient or/and buoyant forces from temperature differences $\left(\nabla_{z} T_{f}>0\right)$ (the subscript $f$ is used here to denote water also outside the borehole exchanger). The Darcy equation would describe the water flow in these cases (Bear, 1979).

In Finnish ground, aquifers with water are found typically up to $50 \mathrm{~m}$ depth. In rock, water flows in fissured bedrock even at 70-100 $\mathrm{m}$ depth, borehole wells have been drilled even beyond $100 \mathrm{~m}$ (Enviroment.fi, 2019). Previous studies on nuclear waste deposits provide some information on deep rock formations. Saline water intrusions have been responsible for the groundwater formation at intermediate depth between 150 and $500 \mathrm{~m}$ (Wallin, 1995). Analyses for Olkiluoto nuclear waste site indicated flows at $600 \mathrm{~m}$ depth, the speed of ground water flows were several orders of magnitude lower than close to the ground (Löfman, 1999). In gravel-based esker aquifers (up to $50 \mathrm{~m}$ ) typical in Nordic countries, the groundwater flow can be one to two orders of magnitude higher compared to stationary aquifers, or, up to $1000 \mathrm{~m} / \mathrm{yr}$ (Kangas and Lund, 1994). The implications for deep-heat boreholes, which extend here to $2 \mathrm{~km}$, is that the effects from natural flows may mainly be limited to the upper part of the borehole with higher porosity and where the magnitude of ground water flow thus may be higher. As the heat from the bottom layers are brought up by the inner pipe, these would not lead to loss of collected heat, but rather heat up the cold water from the outer pipe, i.e. pre-heating it. However, in case of using the borehole also for heat storage, the natural flow in rock could lead to increased heat losses. The buoyant natural convection flow could then play some role, whereas when discharging heat from the bedrock, its impact would be insignificant. It is also probable that the upper part of the borehole heat exchanger is lined with some metal tube to prevent the water in the pipe and the ground water to interact.

In the lower layers of the deep-heat storage, the natural ground flow rates are low due to low average porosity. Small natural convection cells could occur at the boundary of cold water and hot rock. The heat transfer rate from natural convection is, however, much lower than from the forced convection in the pipe meaning that effects remain marginal. 
As the borehole is filled with water and the natural thermal gradient in rock is positive, a kind of chimney or thermal plume could hypothetically be envisioned in stand-still. A study by Ohk and Chung (2017) on shorter pipes showed that average heat fluxes in a pipe decrease with the length of the pipe, the same applies when the pipe diameter is decreased. As the borehole diameter is approximately $200 \mathrm{~mm}$ and length $2000 \mathrm{~m}$, the natural convection effect would be negligible.

As a summary of above analysis, it is concluded that the natural flows in bedrock have negligible effect on the borehole performance. 


\section{COMSOL Multiphysics Simulation Model}

A numerical model was developed for the deep borehole using the COMSOL Multiphysics software version 5.4 (COMSOL, 2019) to perform the dynamic thermal analyses. COMSOL Multiphysics is a simulation software especially suited for simulating and analyzing complex problems in physics and engineering, including heat and mass transfer problems, and interconnected physical problems. COMSOL is a modular programming platform and the necessary interlinked equations describing the physical problem can be formulated by 'writing' the equations and linking necessary solver modules.

In the next, the COMSOL model used in this work, the modeling parameters and modules used are described. The basic model used in the thesis is divided into a solid part (rock) and a coaxial tube (borehole), for which the heat transfer are separately modelled in a coupled manner. The modeling modules in COMSOL are called physics interfaces. In this case, the solid and the tube have their own parameters and 'physics'. The coaxial tube need to be treated as an inner and outer pipe, both requiring their own physics interface.

Here features relevant to the present work are included and a more complete description of COMSOL and the modules used are found in the COMSOL Reference Manual and the Heat Transfer Module User's Guide.

\subsection{Model tree and definitions}

The building of the COMSOL model begins with defining the geometry $(2 \mathrm{D}, 3 \mathrm{D}$, cylindrical symmetry, etc.) of the problem object to be solved and the analysis type (time-dependent or stationary). Thereafter, using a so-called model tree, all physics and parameters required for actual modeling can be defined. A illustration of the model tree for the heat transfer problem in this work is shown in Fig. 14.

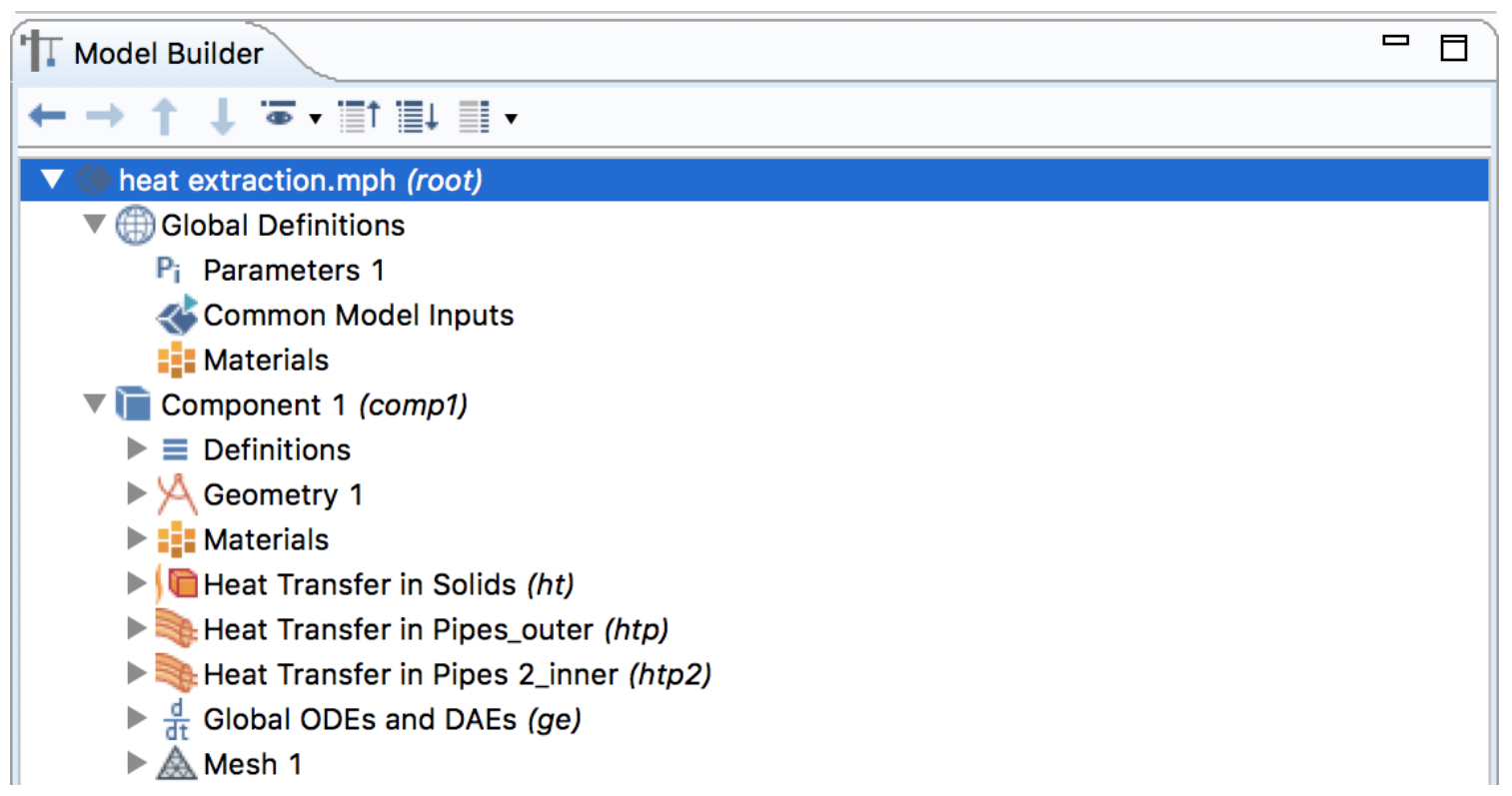

Figure 14. COMSOL model tree (Model Builder) for heat transfer analyses in this thesis. 
The whole modeling process is controlled through the Model Builder window (Fig. 14), which also defines the model tree. It has the necessary functions and operators to build up the models needed, solve these, and presenting the results. The model tree helps to define the data structure, the model object, which stores the state of the model including settings for geometries, numerical mesh, physics models, boundary conditions, studies, solvers, postprocessing, and visualizations, among others (COMSOL, 2019).

The model tree in COMSOL has two default root nodes, the Global Definitions node and the Results node. The Global Definitions node includes a Materials subnode. In the Global Definitions node, all common parameters, variables, functions, and couplings used in the physical models are defined. In addition, values and functional dependencies of material properties, forces, geometries, and other relevant features, which are used throughout the models, can be defined here. Under the Component node (Fig. 15), the specifics of a certain physical component can be defined and in could also include component material properties. In the Results node, the solution can be accessed after the simulation is performed. It includes tools for processing the output data, e.g. graphical presentations (COMSOL, 2019).

In practice, defining the models in COMSOL starts from the top by defining the Global Definitions, and then moving to the Component nodes and finally to the Results node. A full printout of the model tree for the Component node for this work is shown in Fig. 15.

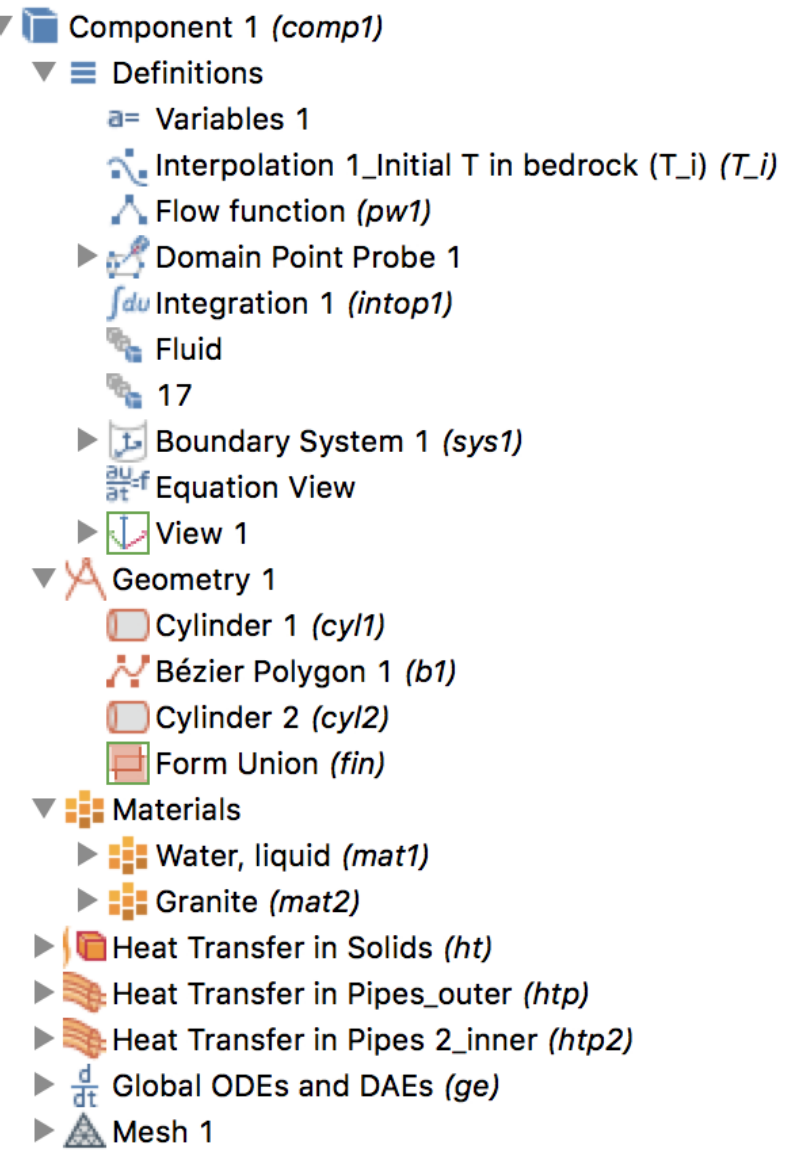

Figure 15. COMSOL Component node in the Model Builder. 
The COMSOL model can have multiple Component nodes. The main difference between the Global and the Component node definition is that the former one applies for the entire model and the latter for the component in question only. A special feature in COMSOL is a probe function, which enables to provide results during the simulations. The probe can be defined to any $(\mathrm{x}, \mathrm{y}, \mathrm{z})$-point in the mode, and it is useful for checking whether the results are sensible or not, enabling to interrupt the calculations, if necessary. The Interpolation function in the Component node (Fig. 15) defines the temperature in the soil as a function of depth.

\subsection{Defining coaxial pipe geometry}

The Geometry function in COMSOL defines the geometry of the objects. A CAD image that defines the geometry of the model can also be used here. An auxiliary volume (shaded cylinder in Fig. 16) can also be defined in COMSOL to which the properties of the soil will be linked in a later material node. The borehole is created inside the auxiliary volume, e.g. in the middle of the cylinder (rock).

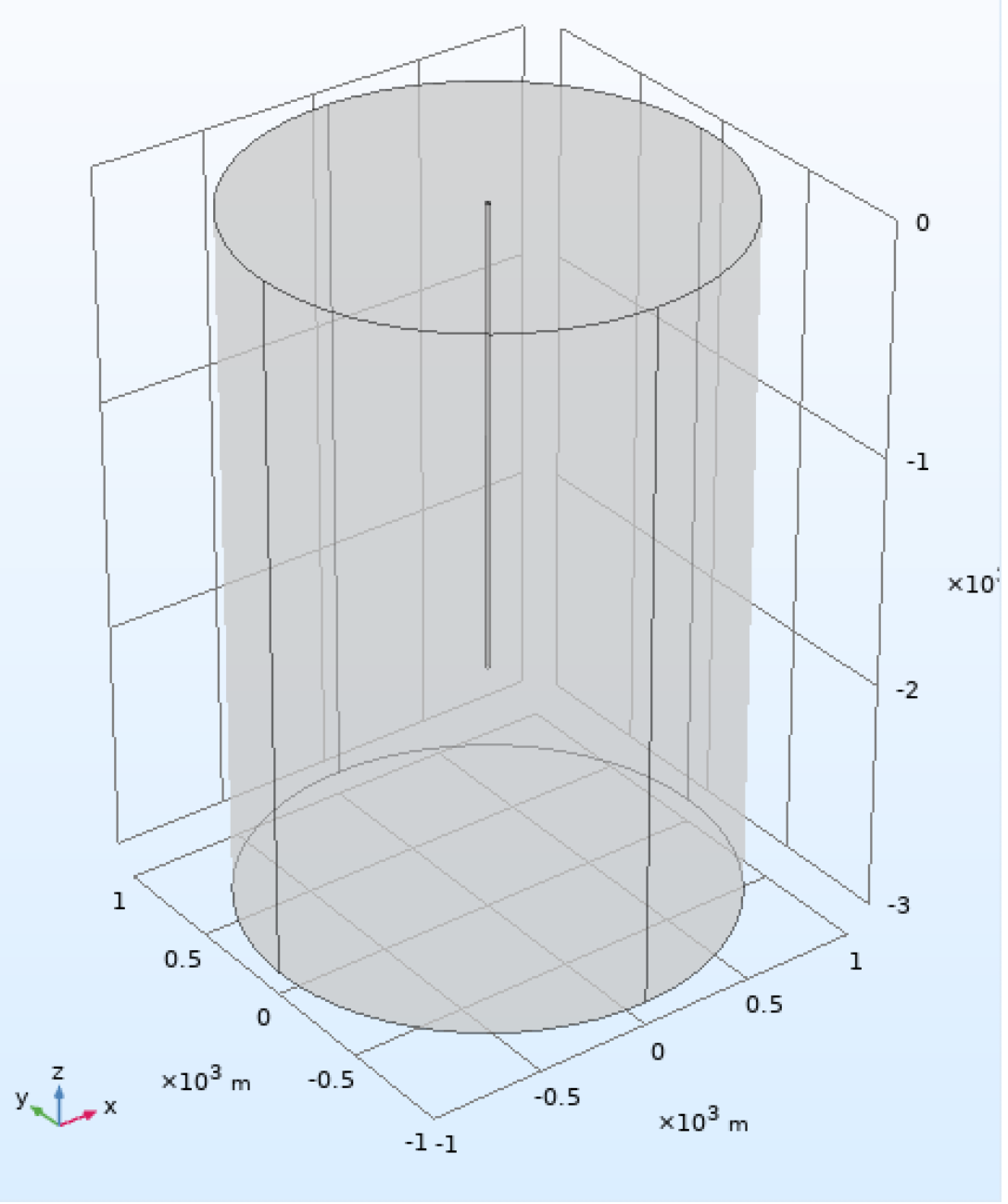

Figure 16. Geometry of the auxiliary volume and deep well. 
In the model, the coaxial pipe is defined by drawing a simple vertical line, defined as a socalled Bezier polygon, which enables to describe a pipe. Next the materials and material properties used in the borehole are defined under the Materials subnode. These can be selected from the COMSOL's materials library or created manually. The properties are temperature dependent. When the desired material is selected, it is placed under the Materials node. In this work, granite (rock) was chosen as the auxiliary volume material, which reflects the bedrock surrounding the borehole. The well was also selected as granite. The material used in the pipe was water, which reflects the fluid flowing through the well.

\subsection{Physical models}

Next the physics for the model was chosen. Heat transfer in solids and heat transfer in pipes were selected for this work. Figure 17 illustrates the model tree for these physical models. The main heat transfer mechanisms accompanied are conduction and convection.

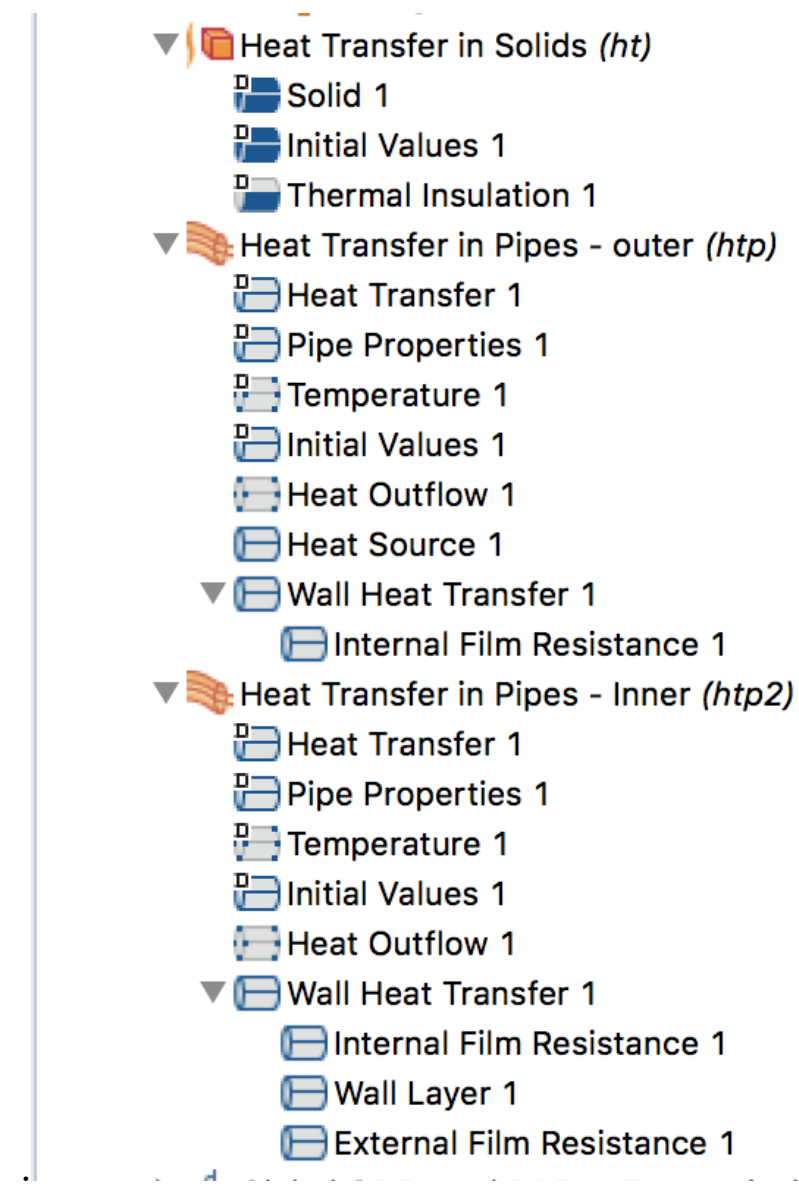

Figure 17. The physics of the COMSOL model and the sub-branches.

The temperature equation defined in the Solid domain shown in Fig. 17 corresponds to the differential form of the Fourier's law that may contain additional contributions such as heat sources or sinks. The default nodes in Heat transfer are Solid, Initial Values, and Thermal 
Insulation (default boundary condition). Other boundary, edge, and point nodes can be added, but these were unnecessary in this model.

The Heat Transfer in Pipes is used to model the heat transfer by conduction and convection in the pipe. The corresponding interface is modelled separately for the inner and outer pipes. The default nodes are in this case Heat transfer, Pipe Properties, Temperature and Initial values. Other nodes that can be added for both inner and outer pipes are Heat Outflow and Wall Heat transfer. The Heat Outflow node expresses, as its name suggests, the point where the fluid flows out, in case of the outer pipe it is the bottom of the pipe, and for the inner pipe, it is the top of the pipe. The Wall Heat Transfer node sets up the heat exchange across the pipe wall. By default there is an internal film resistance. For the inner pipe, the Wall Layer and External Film Resistance represent the thermal conductivity and wall thickness between the inner and outer pipe, respectively. Because of this, one must add a Heat Source node to the outer pipe and connect it to the wall layer in the inner pipe.

After defining the physics of the inner and outer pipe, the models need to be interconnected. This is done e.g. by defining the outgoing temperature variable from the outer pipe to the inlet of the inner pipe.

\subsection{Meshing}

When a new model is added to the model tree, a meshing sequence will automatically be added displayed as a Mesh node to enable a numerical solution of the problem defined. The model may have a number of meshing sequences, but in the presented model will just the one. Mesh properties are created and defined either by COMSOL itself or it can be userdefined. Figure 18 describes the mesh in the model tree of COMSOL.

The mesh is created either automatically by COMSOL by selecting the "physics-controlled mesh'-option or it can be user-defined. When user-defining the mesh by selecting the 'usercontrolled mesh'-option, the customization could be based on selecting the largest and smallest size of the computational elements, the growth ratio (limits the size difference of two adjacent mesh elements; if lower value then finer mesh), and other variables affecting the density of the grid.

The computation time and computer memory needed for the finite element solving is very much affected by the mesh chosen and the number of mesh elements, for which reason this is an important step in the whole calculation process. Typically, the 'physics-controlled mesh'-option contains a considerable number of elements leading to a time-requiring solving process. Therefore, in this thesis a 'user controlled-mesh'-option was employed enabling both mesh definition and meshing sequencing by the user itself. In fact, meshing is a very memory-intensive step, when setting up and solving a finite element problem. 


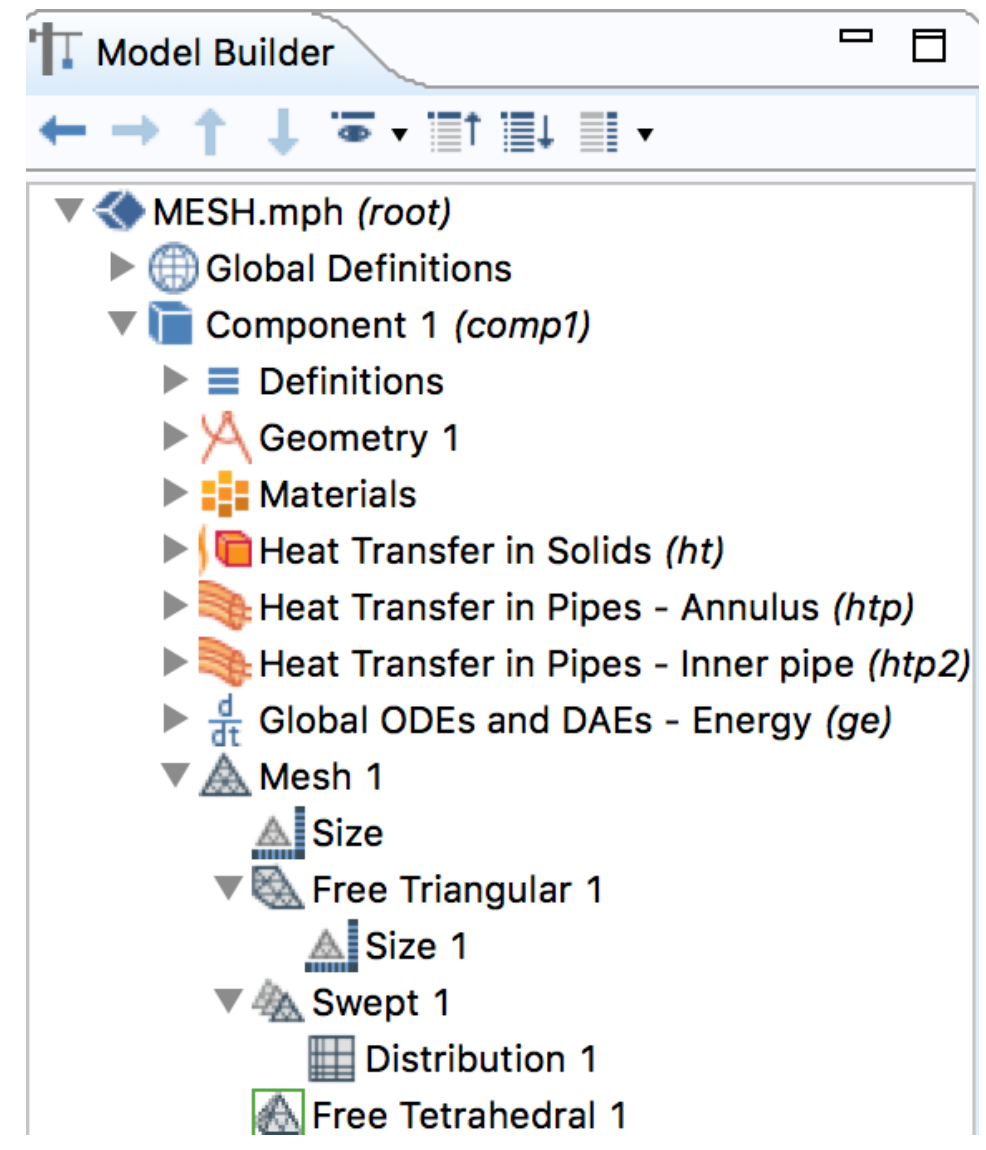

Figure 18. Mesh in the model tree.

Figure 19 shows the basic mesh used here for the deep-well simulations. Here the so-called swept mesh geometry discretization technique was employed. A swept mesh starts at a source boundary and then sweeps along it to a specified destination boundary. The method is useful for thin geometries such as a borehole, as e.g. tetrahedral and triangular meshes would create more elements than is necessary to account for the skewed dimensions that exist within a thin geometry. The swept mesh creates hexahedral (default) or prismatic mesh elements, which can effectively handle the disproportional dimension sizes with less elements (COMSOL, 2019). 


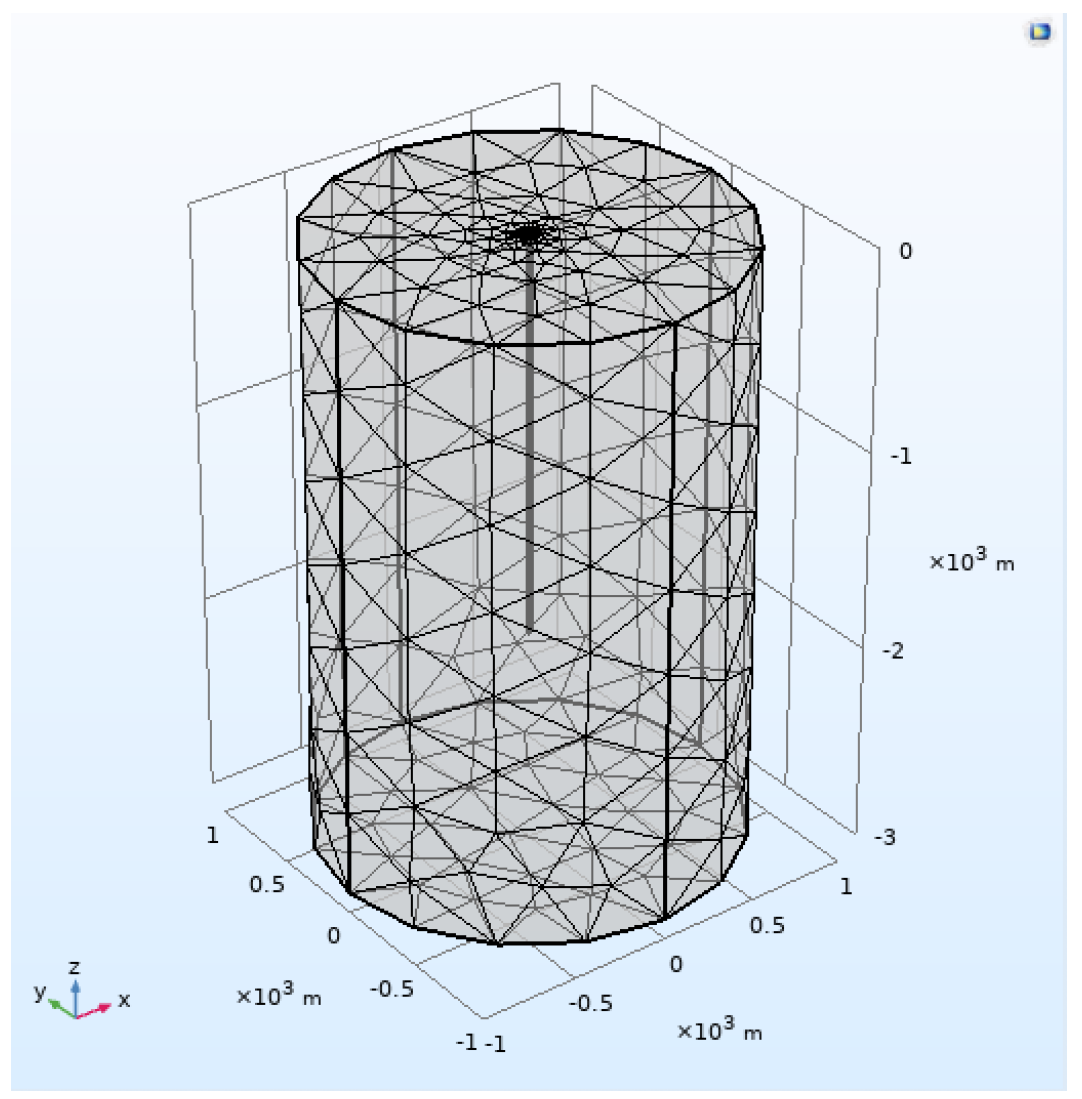

Figure 19. User-defined mesh in the simulation model.

When using the user-defined mesh sequences, different features are available. For example, the features can be defined for different parts of the geometry, or, the number, size and distribution of elements can also be controlled. The boundary/edge/domain layer mesh can be defined for the entire geometry or for a specific region. The element types available are quadratic, tetrahedral, and triangular. The element size can be chosen between a preset element size (ranges from extremely fine to extremely coarse) and a user-defined size.

Before choosing the mesh for the simulations of the borehole, several types of meshes were investigated against their accuracy and computational time. Intuitively, a coarse mesh would require the least computational time, but also the least accuracy, whereas a dense mesh would give the opposite. Four types of meshes were investigated, one was the 'physics-controlled' mesh and the three other 'user-defined' ranging from coarse to fine meshes. Figures 20-23 illustrate the potential mesh structures for a single borehole. The 'physics-controlled' meshes employed quadratic shape functions. 

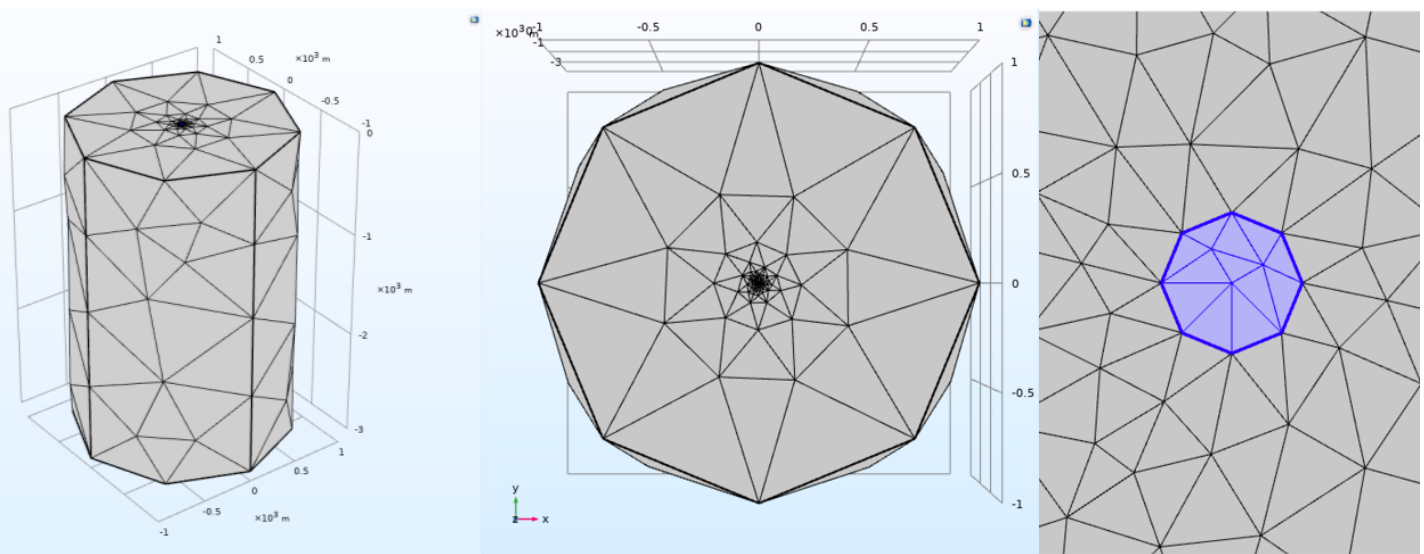

Figure 20. 'User-defined' coarse mesh.
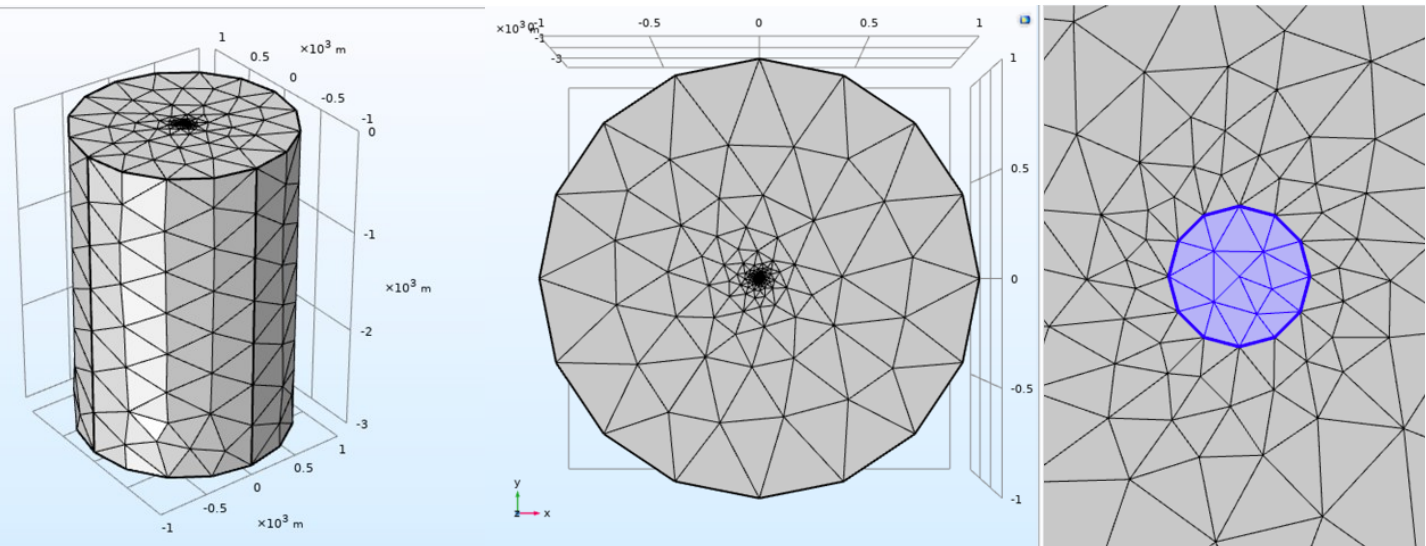

Figure 21. 'User-defined' medium-level mesh.
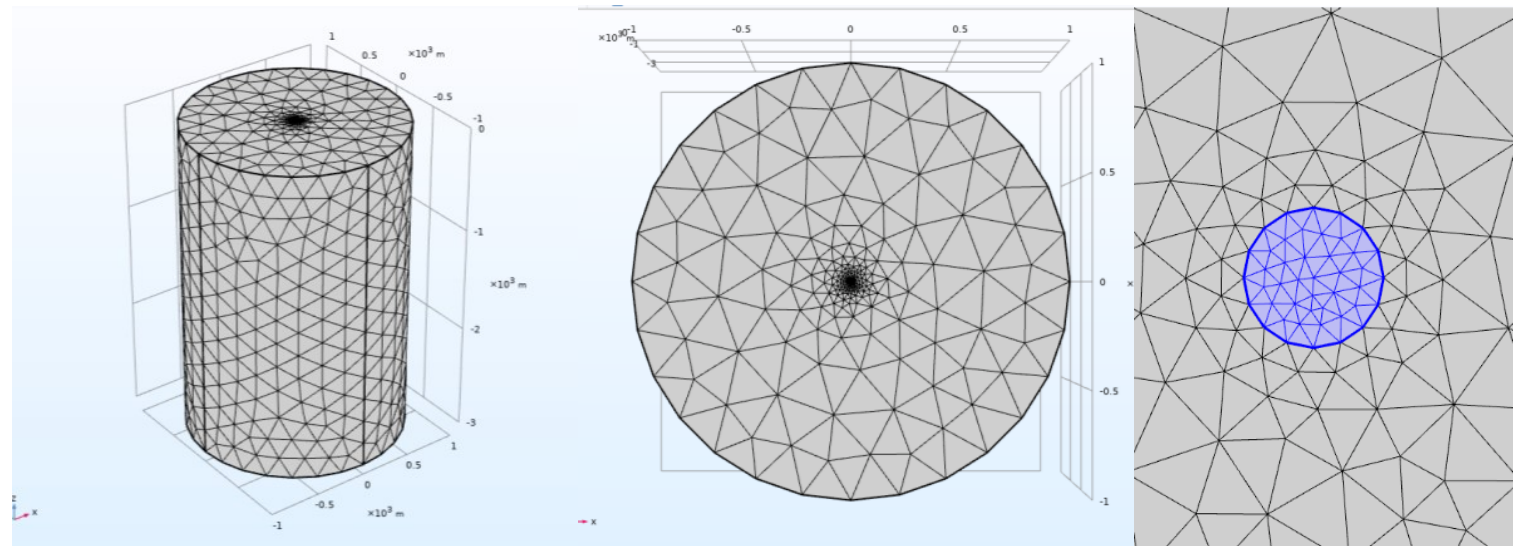

Figure 22. 'User-defined' dense mesh. 

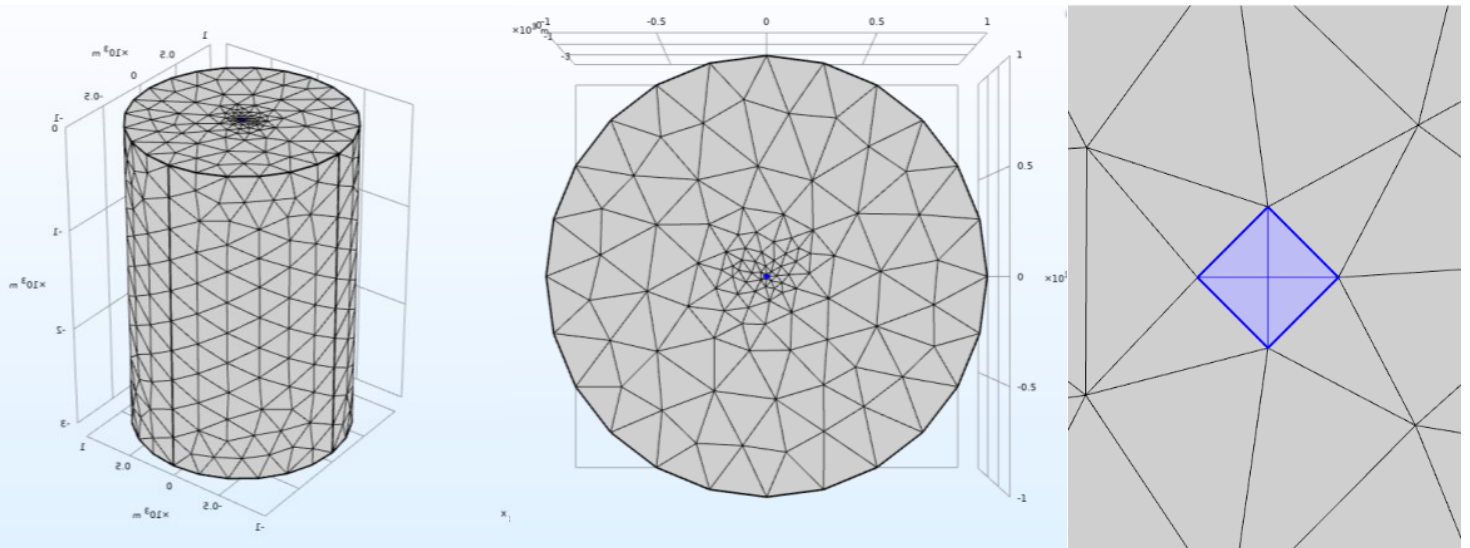

Figure 23. 'Physics-controlled' mesh.

Visual inspection of the meshes reveals major differences between the 'user-defined' meshes, in particular in the surroundings of the borehole. With a 'user-defined' coarse mesh the relatively thin network outside the borehole could lead to inaccuracies in describing the temperature field in the rock, which would reflect back to the borehole through the boundary conditions.

Next a test simulation with the different meshes were done for a single borehole extracting heat from the rock continuously with a constant flow rate. The simulation outcome extending to 25 years of heat extraction is shown in Fig. 24.

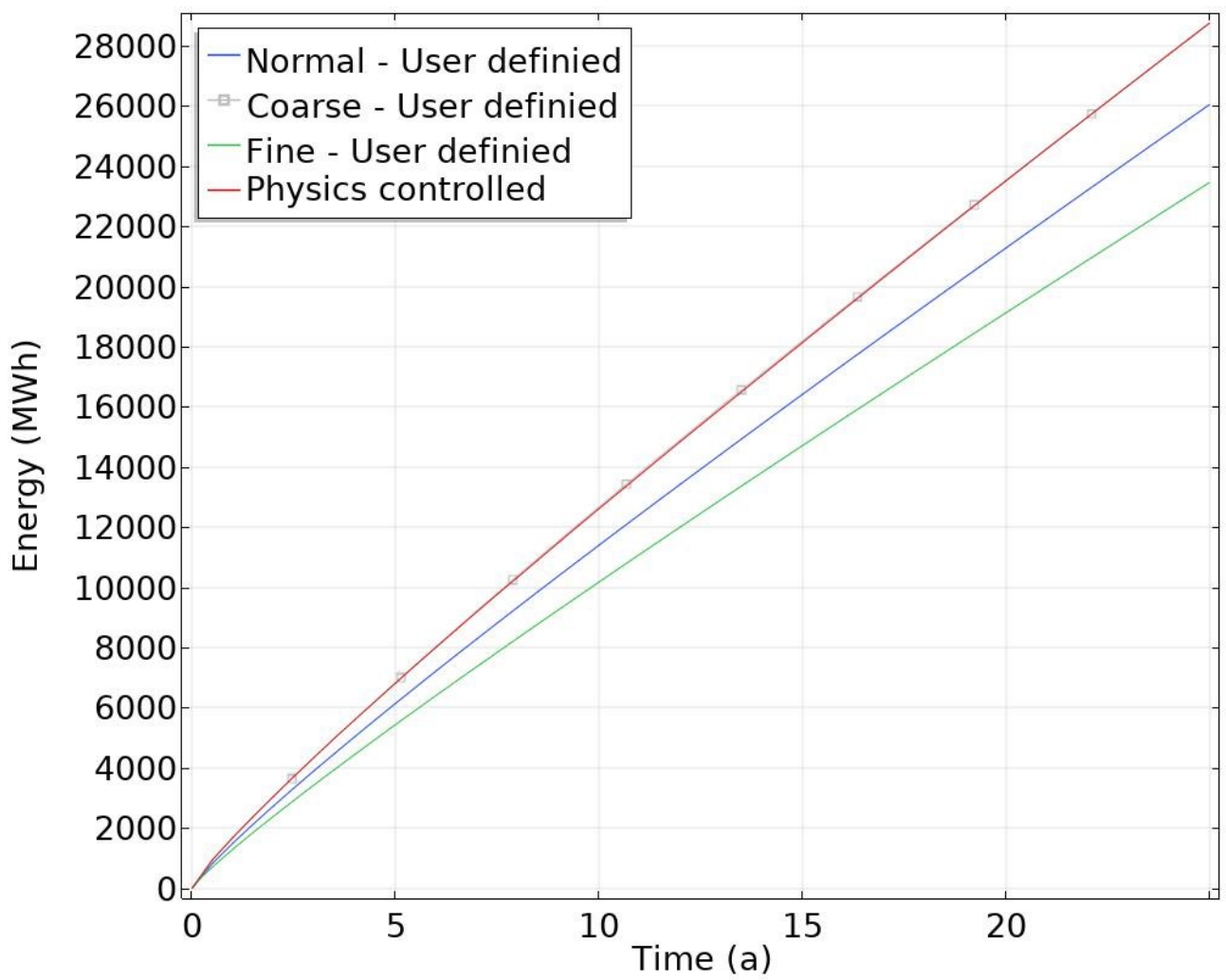

Figure 24. Comparison of cumulative extracted heat from a borehole with different mesh types as a function of time. 
The differences between the different mesh types are small for short simulations of a couple of years, but the differences becomes distinctive on a long-term, e.g. in this test case the spread was around $20 \%$ after 25 years of heat extraction. Such a difference could already influence the economic valuation of a deep-heat system. The automatic 'physics-controlled' mesh and the 'user-defined' coarse mesh gives almost same result, but the largest deviation compared to the fine grid, which should by definition yield the most accurate result. The medium-level grid falls in between the two others (max. 10\% deviation) and was chosen as the reference grid for this study. The wall-clock time of a single 25 -year simulation with this mesh was 2 hours compared to 12 hours with the fine grid and 0.5 hour with the coarse grid The runs were made in this case with a Macbook Pro PC (Intel core i5 2.3 Ghz, 8GB).

\subsection{Solvers}

The models created in COMSOL are typically solved either with a time-dependent or stationary solver. When selecting a time-dependent solver, the desired simulation time and time step length are set by the user. The solver settings can be adjusted to affect the computation error, maximum number of iterations, relaxation factors, iteration termination conditions, etc. Also, the numerical data in the simulations can be selectively saved based on what outcomes the user needs, e.g. in our case the borehole and the surrounding rock would be of primary interest. An important feature of the time-dependent solver is the size of the maximum step, which affect both the accuracy and the simulation time.

In case of a linear solution, e.g. when simulating a coaxial tube with heat extraction only, the automatic step definition of COMSOL could be used. Then a shorter time step would be used in the beginning, and it would grow with time. However, if in such a case a 'transient' were created, e.g. the mass flow would change, COMSOL might assume that the well still operates in a linear fashion, and would overlook the change. In such a case, the time step need to be set manually. Figure 25 and 26 illustrates how the time step is set in COMSOL. The option 'constant' in Fig. 26 represents the standard maximum time step option defined by the user. In simple modelling tasks, the COMSOL automatic step feature is used here, but for the more complex cases either a maximum step of 2.5 days or 7.5 days was used.

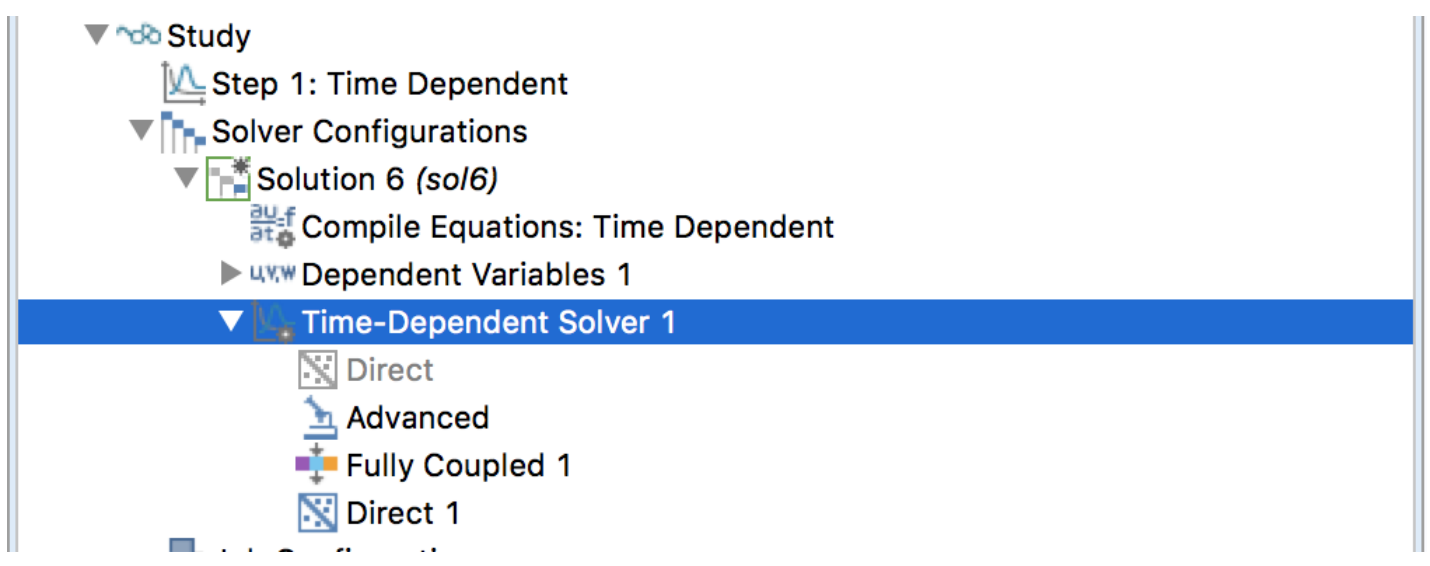

Figure 25. The time-dependent solver in the model tree of COMSOL. 


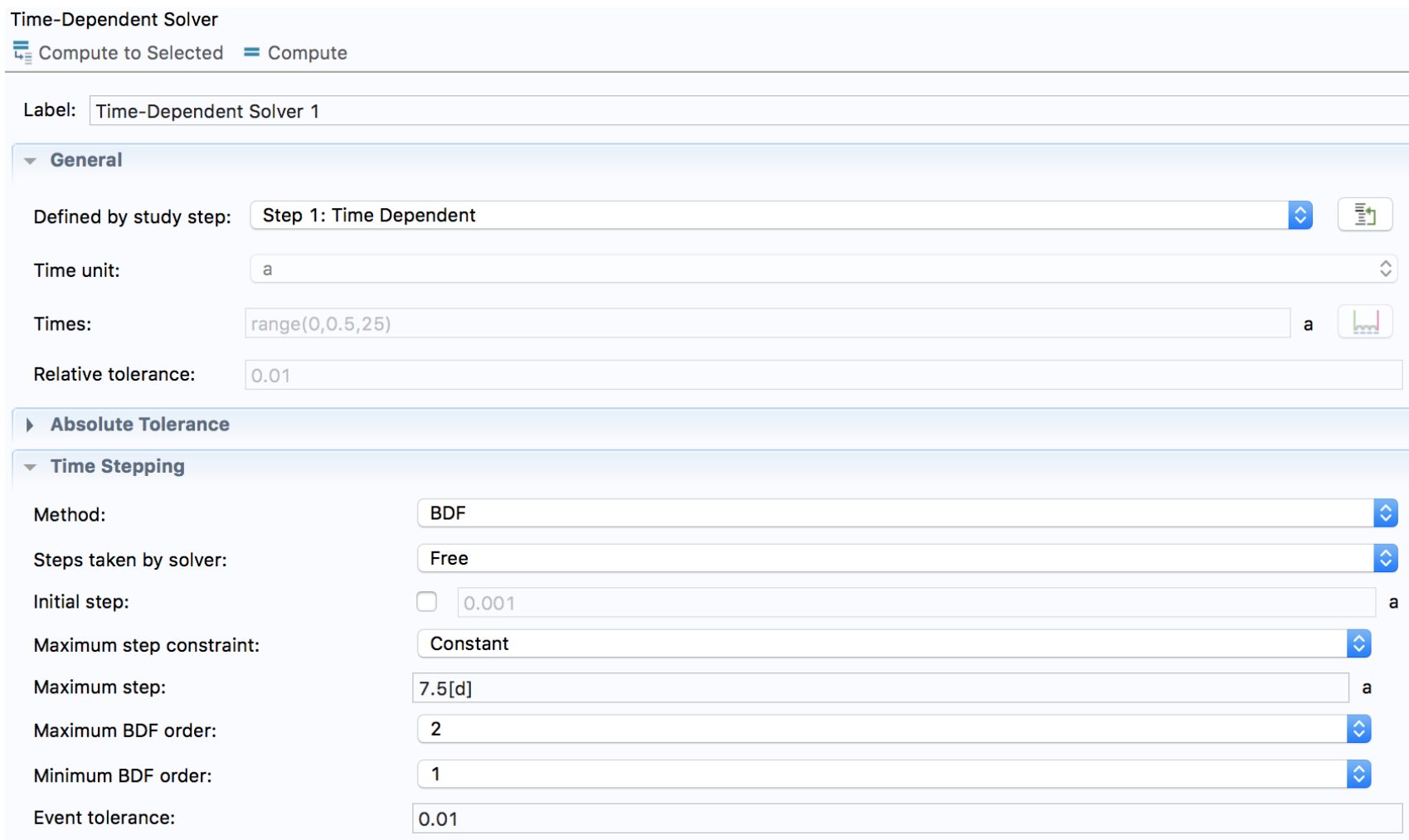

Figure 26. Illustration of the parameter setting in the time-dependent solver.

The results from the simulations are automatically presented and post-processed. However, it is possible to create almost an unlimited number of graphs and tables in COMSOL. The results of the calculation can also be used to calculate various numerical values. For example, in the case of a thermal well, the power produced is an interesting quantity and can be calculated according to the example of Eq. (7). All numeric data can be stored in a text document, which can be obtained, for example, in Excel for processing. The results obtained in this thesis are discussed in the Section 8. 


\section{Verification of the model}

Full validation of the simulation model through experiments was outside the scope of the thesis as there is not yet data available on using coaxial tubes for geothermal heat and such experiments would also be costly and would last for several years.

As an alternative to validation, verification of the present model to previous numerical studies was chosen as the approach. However, most of the studies available on modelling consider the more popular U-tube configuration, whereas the work on coaxial tubes is scarce.

Holmberg's doctoral thesis (Holmberg, 2016) dealt with geothermal heat with coaxial tubes and this work was taken as a reference work for the present study. A one-to-one comparison was not fully possible due to different parameters and starting values used for the simulations in Holmberg's work, e.g. the depth of the wells were limited to $300-1000 \mathrm{~m}$. The 2000-meter well employs different physical parameters. The 800-meter well from Holmberg was the closest case to the present work and was chosen for comparison.

In the case study of the 800 meter deep well, $1{ }^{\circ} \mathrm{C}$ water was fed at $4 \mathrm{~kg} / \mathrm{s}$ producing $4{ }^{\circ} \mathrm{C}$ warm water on average. Holmberg performed cyclic tests with a $24 \mathrm{~h}$ intake and $24 \mathrm{~h}$ pause with a total simulation time of $5000 \mathrm{~h}$. The thermal gradient of ground was $20 \mathrm{~K} / \mathrm{km}$. The average output power was $50 \mathrm{~kW}$.

The COMSOL model comparison was done with a continuous operation of the borehole, since the initial power output from the borehole is not affected by a continuous or cyclical input. The resulting temperature and power profiles over time are shown in Fig. 27. The steady-state value settles around $4.2{ }^{\circ} \mathrm{C}$ and $55 \mathrm{~kW}$, which coincides well with Holmberg's results (e.g. Fig. 11). 


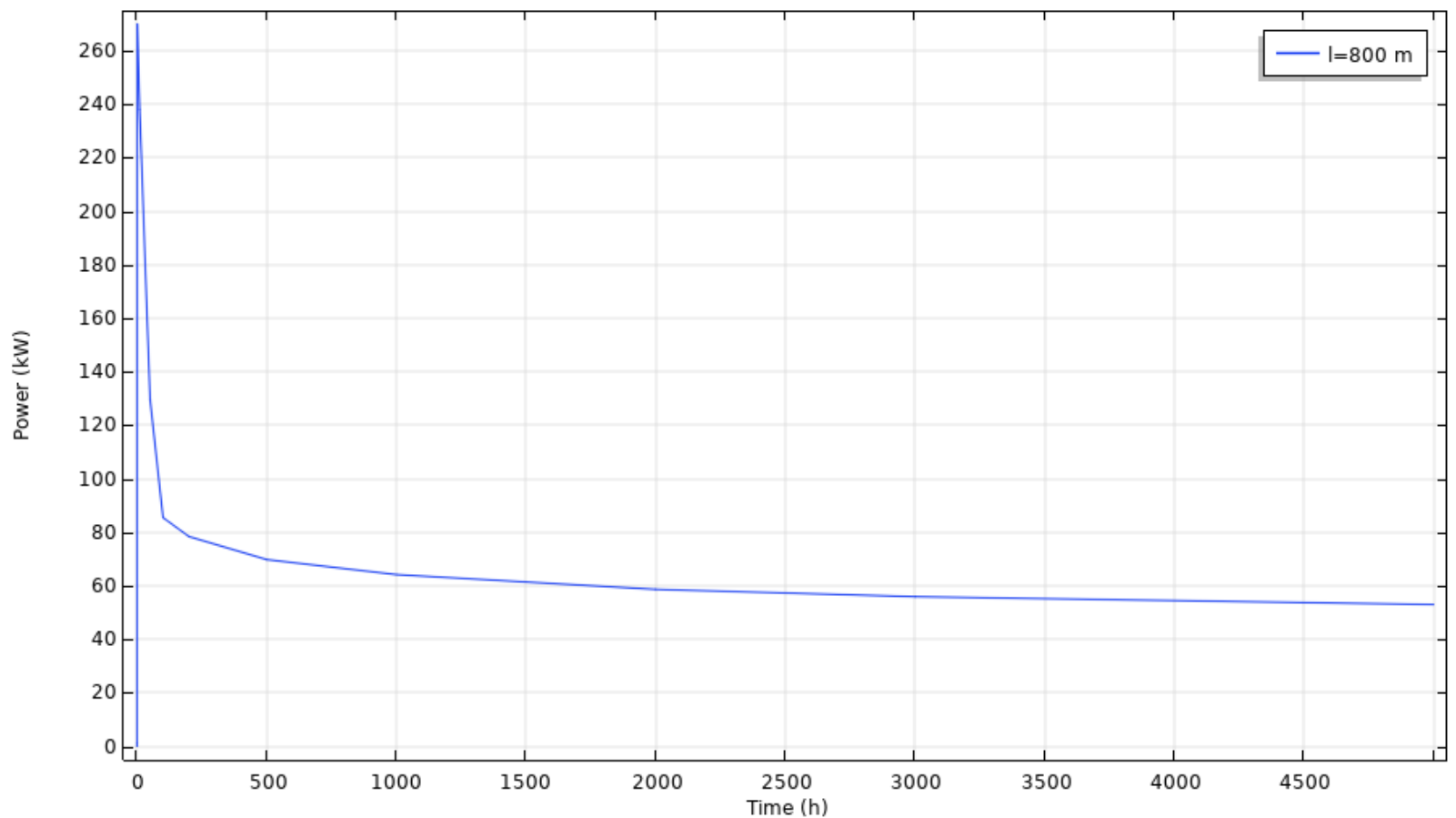

(a)

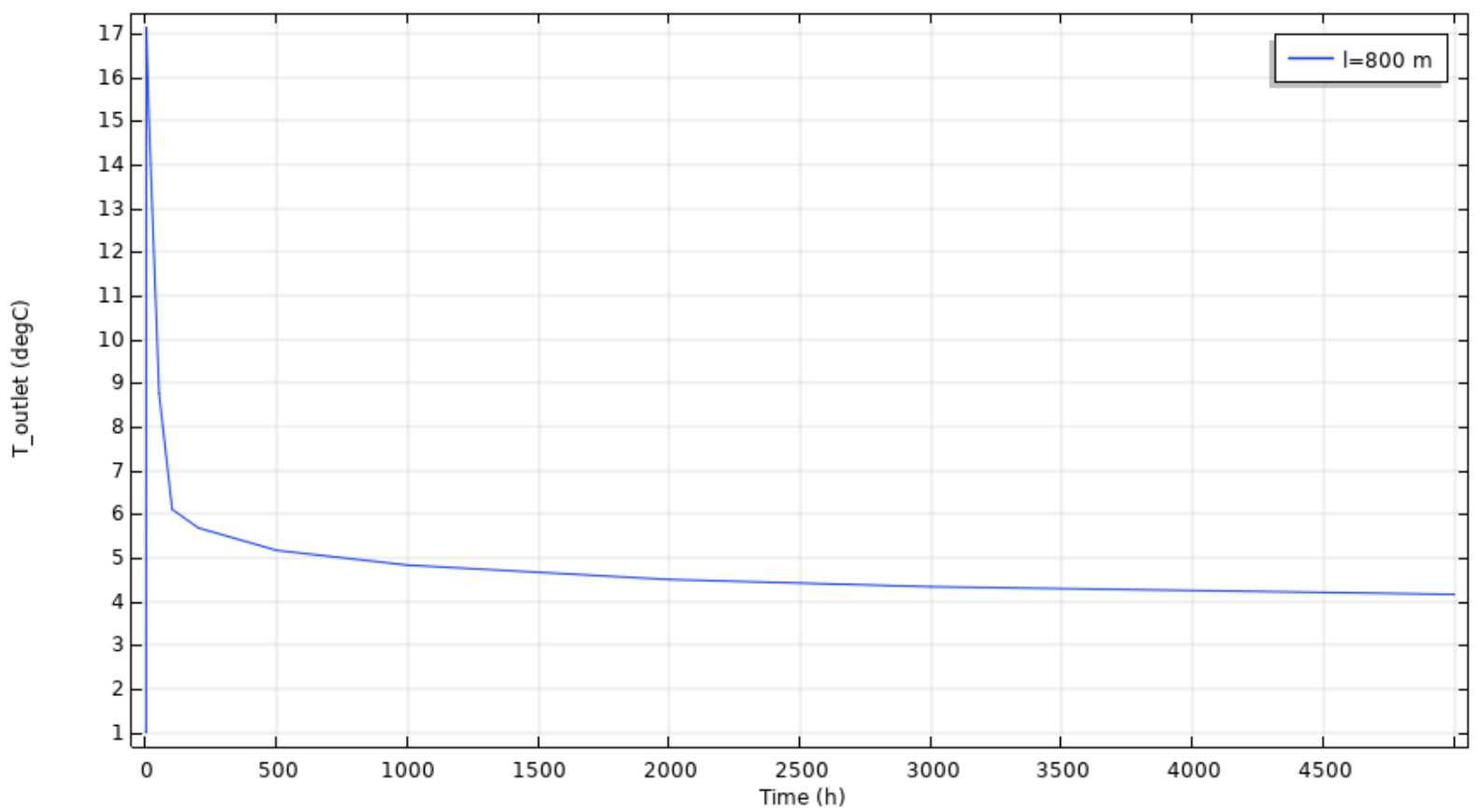

(b)

Figure 27. Test simulation for model verification. (a) Power, (b) fluid temperature from the borehole as a function of time. Depth of well is $800 \mathrm{~m}$. 


\section{Simulation results}

\subsection{Cases and parameter values}

In this section, the main results from the simulations of the deep-well system is discussed. Most of the simulations concern the heat extraction from the borehole and its thermal performance against a range of parameter variations important to the practical design of such systems.

The simulation runs were done for a 25 -year period which typically corresponds to the lifecycle of heat pump systems, but also enables to detect any major changes in the surroundings of the borehole. Though the economics of the borehole exchanger was outside the scope of this work, the deep-heat well systems are typically capital intensive dominated by the drilling costs, for which reason a long life-time would be important.

A reference case was defined for the simulations, against which the parameter variations were done. The parameters of the reference case are shown in Table 1. These would correspond to a typical deep-heat well system in average conditions in Finland. The technology parameters correspond to those used in the first pilot-plan at Koskelo-site in Espoo, Finland, where a vacuum tube-type of borehole heat exchanger is used.

Table 1. Parameter values for the reference case.

\begin{tabular}{|ll|}
\hline Parameter & Value \\
\hline Type of fluid & Water \\
Borehole length & $2000 \mathrm{~m}$ \\
Mass flow rate & $6 \mathrm{~kg} / \mathrm{s}$ \\
Thermal conductivity between center and outer pipe & $0.02 \mathrm{~W} / \mathrm{mK}$ \\
Geothermal gradient & $20 \mathrm{~K} / \mathrm{km}$ \\
Diameter of the center pipe & $76 \mathrm{~mm}$ \\
Diameter of the outer pipe & $192 \mathrm{~mm}$ \\
Wall thickness of center pipe & $17 \mathrm{~mm}$ \\
Inlet temperature by heat extraction & $6^{\circ} \mathrm{C}$ \\
Thermal conductivity of rock & $3 \mathrm{~W} / \mathrm{mK}$ \\
\hline
\end{tabular}

A 25-year simulation of the reference case would typically require a few minutes on a PC, whereas the more complex cases could require up to half a day, for which cases more powerful computing resources would be recommended, e.g. with Aalto University computers a run took ca 2-4 hours.

Four cases with different operational strategies were investigated as follows:

1. Heat extraction only;

2. Heat extraction with recovery periods;

3. Heat extraction and injection cycles;

4. Heat extraction with a predetermined power rate. 
In Case \#1 heat was only extracted from the well. In this case, an extensive parametric study was also made to investigate how different parameters affect the performance of the deepheat well. In Case \#2, the thermal well was also used for heat extraction, the well was allowed to rest and recover in between extraction periods. In Case \#3, the performance of the heat well under a cyclic heat extract and inject strategy was analyzed; this case also corresponds to storing heating in the rock as a 6-month cycles were employed. Case \#4 corresponds to coupling the heat well with a building energy system, i.e. the output of the well follows the heat consumption of the building. For this case, a PID controller was incorporated into COMSOL enabling control of the mass flow rate to match with a predetermined heat demand profile.

\subsection{Analysis of the reference case (Case \#1)}

The thermal performance of Case \#1 with parameter values given in Table 1 is shown in Fig. 28. As expected, both the output power and temperature decline over time. The largest drop in power takes place during the first 5 years, after which the performance of the hole settles to an average power of $100-120 \mathrm{~kW}$. The temperature of the outlet water drops by $1{ }^{\circ} \mathrm{C}$ in 5 years, and at the end of the 25 -year simulation the water has cooled down by $2.5^{\circ} \mathrm{C}$ yielding then around a $10^{\circ} \mathrm{C}$ outlet temperature. The total heat energy extracted during the first five years comes to $6 \mathrm{GWh}(1.2 \mathrm{GWh} / \mathrm{yr}$ on average) and to $25 \mathrm{GWh}$ in 25 years $(1 \mathrm{GWh} / \mathrm{yr}$ on average) .

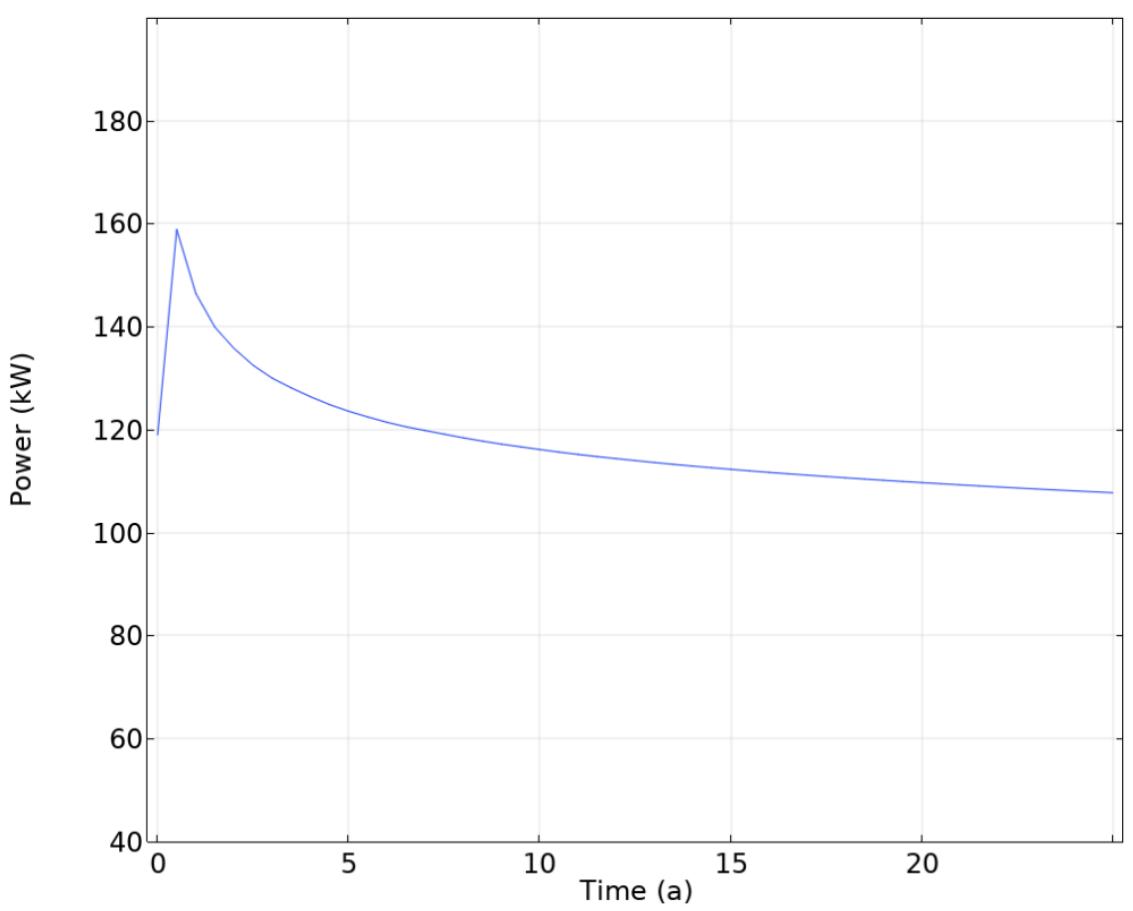

(a) 


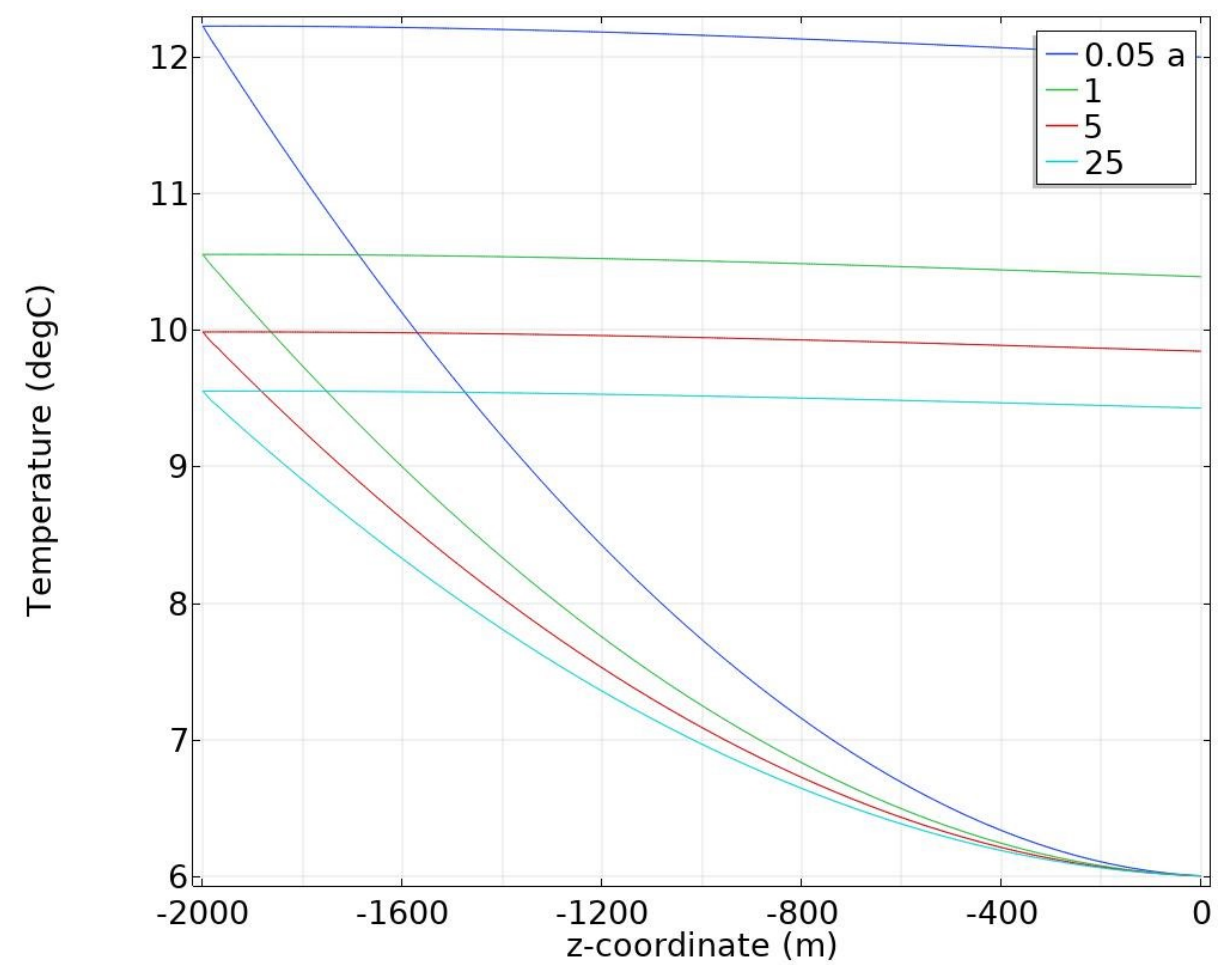

(b)

Figure 28. (a) Power output and (b) temperature (forward and return) in the deep-heat well for the reference case (Case \#1). Z-coordinate $0 \mathrm{~m}$ refers to the ground surface.

The cooling of the surrounding rock is illustrated in Fig. 29 at a $2 \mathrm{~km}$ depth after 1, 5, and 25 years for heat extraction. The immediate thermal influence ranges to some 10 meters from the well after 25 years leading to max. $10{ }^{\circ} \mathrm{C}$ temperature drop in the rock. A weaker impact $\left(<5^{\circ} \mathrm{C}\right)$ extends to several tens of meters.

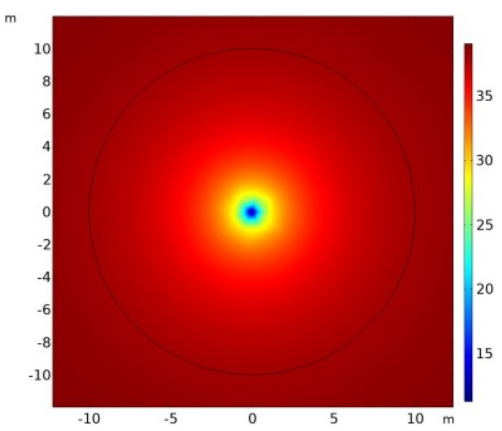

(a)

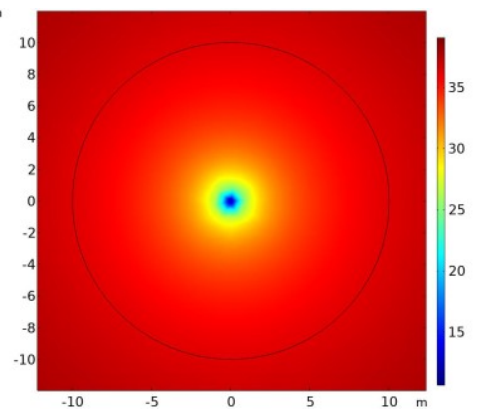

(b)

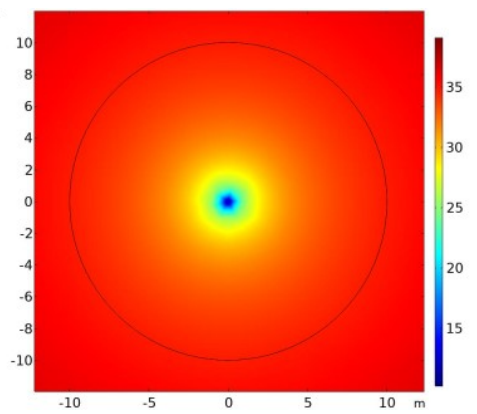

(c)

Figure 29. Rock temperature in the surroundings of the bore-hole in reference case (Case \#1) after 1, 5, and 25 years of continuous heat extraction. (a)-(c) shows the temperature profile at $2 \mathrm{~km}$ depth in the $\mathrm{x}-\mathrm{y}-$ plane.

Figure 30 demonstrates the temperature profile at $1 \mathrm{~km}$ depth in the $\mathrm{x}$-direction during 25 years of operation. The cooling of the rock expands gradually and symmetrically with time, but the pace is still moderate. 


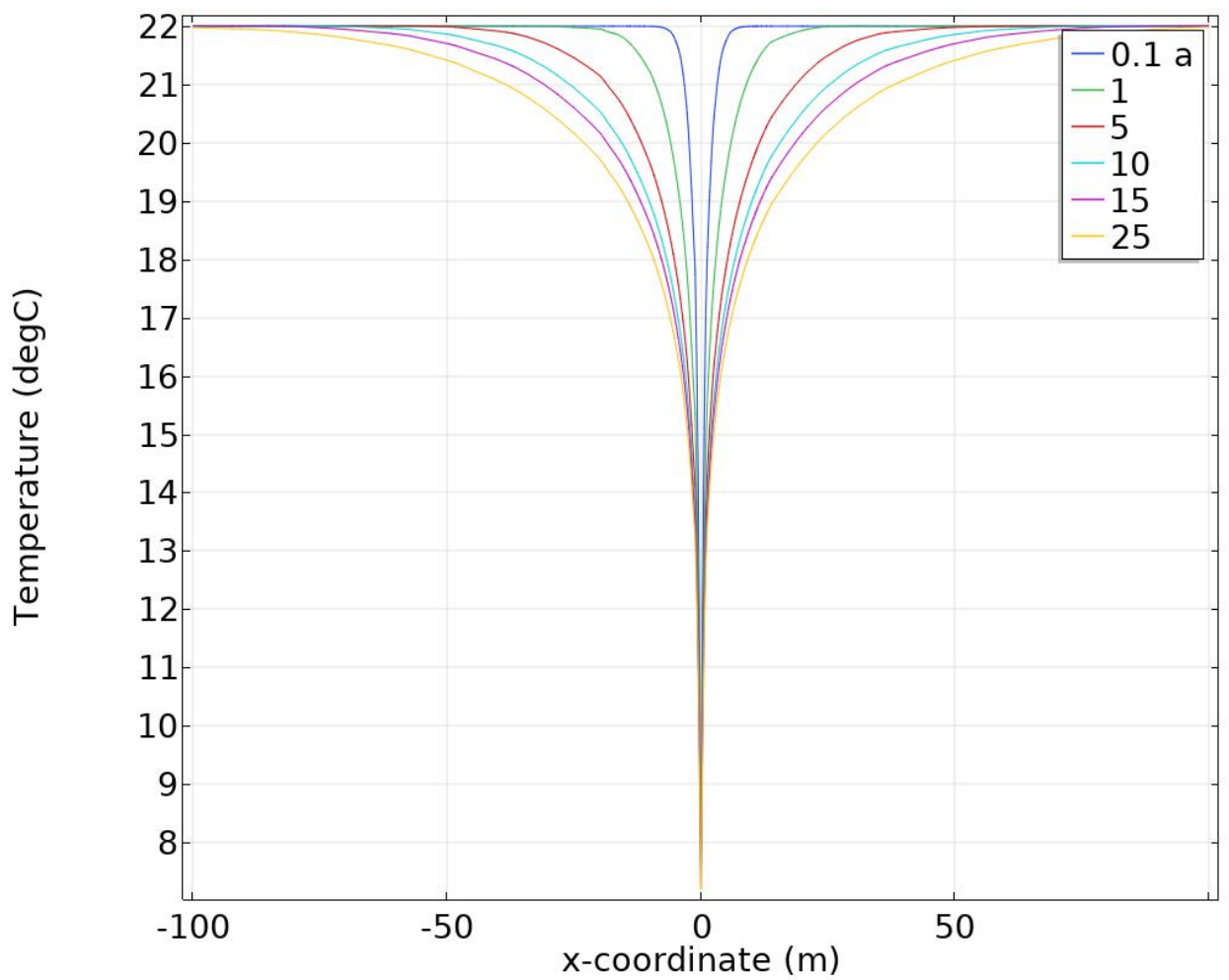

(a)

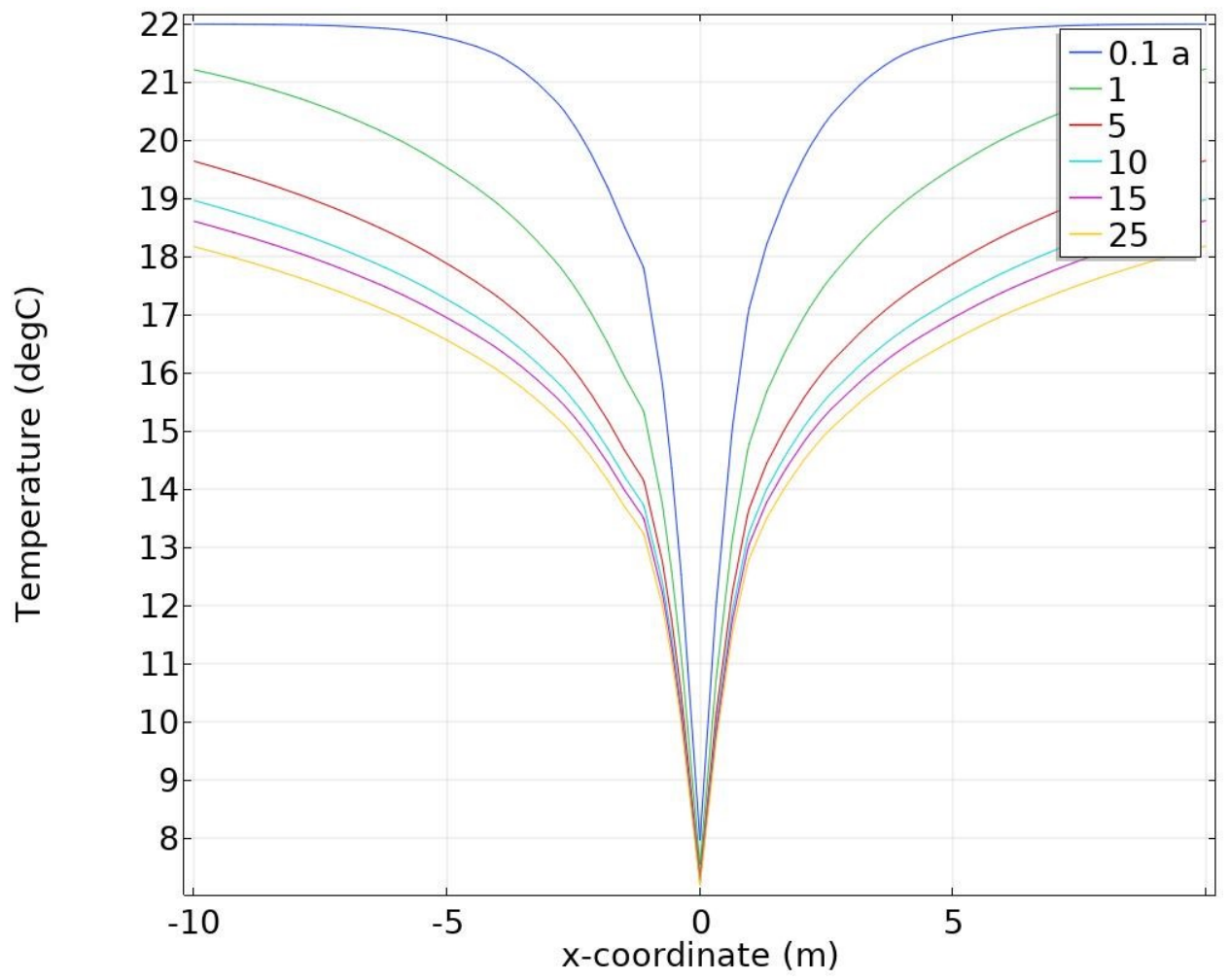

(b)

Figure 30. Expansion of the cold front in the rock with time. Temperature distribution shown at $1 \mathrm{~km}$ depth. The borehole is at point $0 \mathrm{~m}$. 


\subsection{Thermal short-circuiting in borehole heat exchanger}

An important common technical parameter for all the cases is the characteristics of the coaxial pipe in the borehole. In particular, the thermal conductivity between the center and outer pipe influences the possible thermal short-circuiting of the downward and upward flows, which would significantly affect the effectiveness of the deep-well system. The materials for the coaxial pipe have a major impact on the heat transfer between the inner and outer pipes. For U-pipes polyethylene (PE) is a commonly used material with $\lambda=0.42 \mathrm{~W} / \mathrm{mK}$. Polypropylene has also been used with $\lambda=0.1-0.22 \mathrm{~W} / \mathrm{mK}$ (Engineering Toolbox, 2019). The vacuum tube, also used here, is a new development, which has shown very low conductivity of $\lambda=0.02 \mathrm{~W} / \mathrm{mK}$.

The effect of the thermal conductivity of the pipe on the well performance is shown in Fig. 31 for mass flow rate $6 \mathrm{~kg} / \mathrm{s}$ (reference case) and for a lower rate of $2 \mathrm{~kg} / \mathrm{s}$. The differences in the steady-state output power with the higher rate is less than $10 \%$, whereas at lower rate the difference grows, e.g. with $2 \mathrm{~kg} / \mathrm{s}$ the difference could grow close to $50 \%$ between the vacuum and PE pipe. Figure 31 (b) demonstrates the increasing heat transfer rate between the pipes with increasing thermal conductivity, which then explains the increasing 'shortcircuiting'.

These results indicate that with higher flow rates thermal short-circuiting can be more easily avoided. Whereas at low flow rates, the thermal conductivity of the pipe material should be low (large thermal resistance between the center and outer pipe).

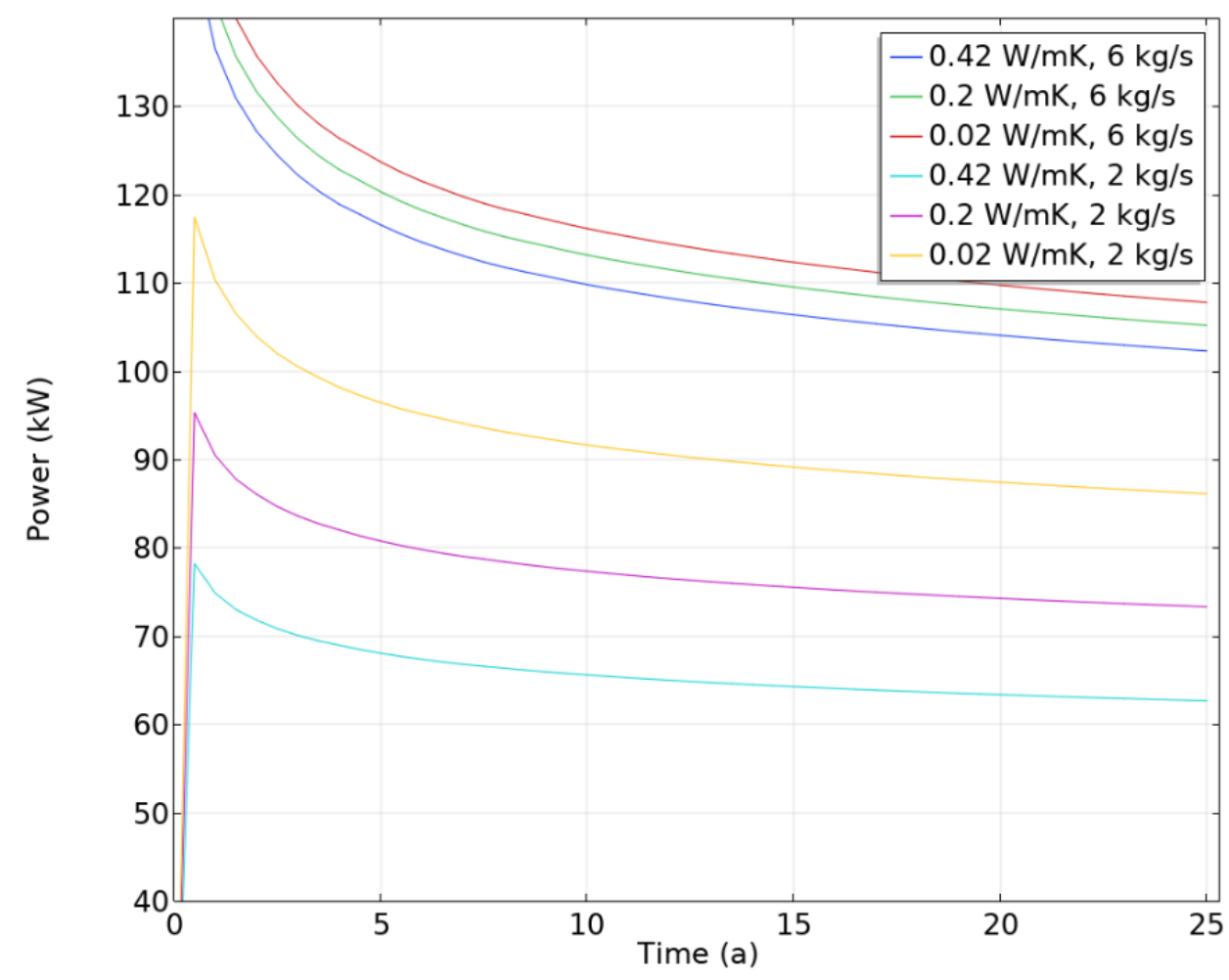

(a) 


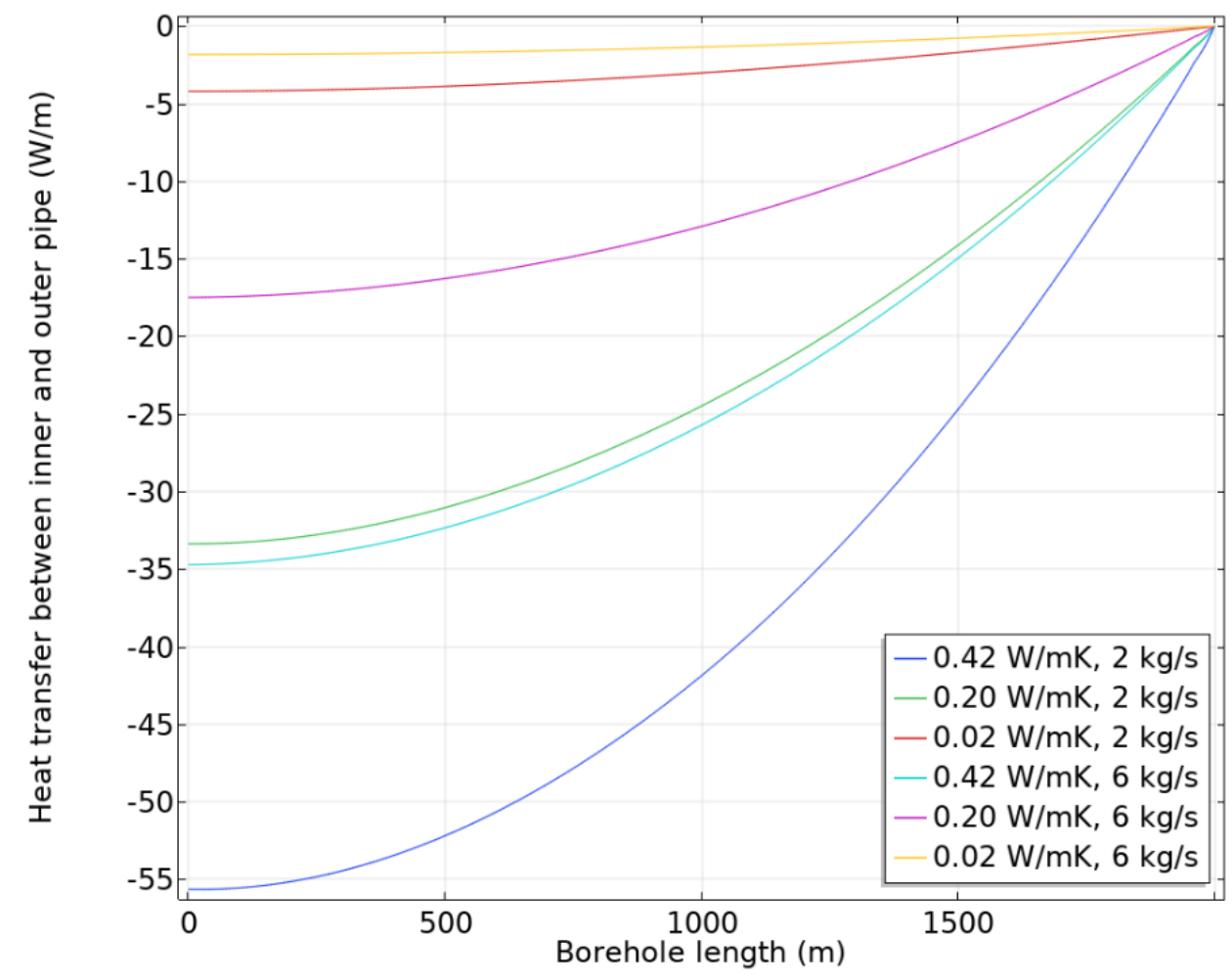

(b)

Figure 31. Effect of pipe thermal conductivity on (a) power from the borehole, (b) heat transfer between the pipes in the borehole.

\subsection{Effects of bedrock characteristics}

Next the effects of rock parameters on the performance of the borehole was analyzed, also to understand the sensitivity of long-term performance on parameter uncertainties.

As first test, the effect of the thermal gradient was analyzed by varying the reference value by $\pm 5^{\circ} \mathrm{C} / \mathrm{km}$ or by $\pm 25 \%$, which would still be within the range of possible values in Finland. Figure 32 shows the development of the output power and accumulated extracted energy for the reference case (Case \#1) with these values. The differences in the almost steady-state power at $\mathrm{t}=25$ years would be $\pm 30 \%$. In terms of accumulated extracted energy, the differences are much larger. The $25 \mathrm{~K} / \mathrm{km}$ gradients gives already at $\mathrm{t}=5$ years double the energy than $15 \mathrm{~K} / \mathrm{km}$ and at $\mathrm{t}=25$ years the difference is almost $190 \%$ i.e. the differences in the extracted energy increase over time. But more importantly, the geothermal gradient has a major effect on the performance of the deep well, which may be important when locating potential sites. 


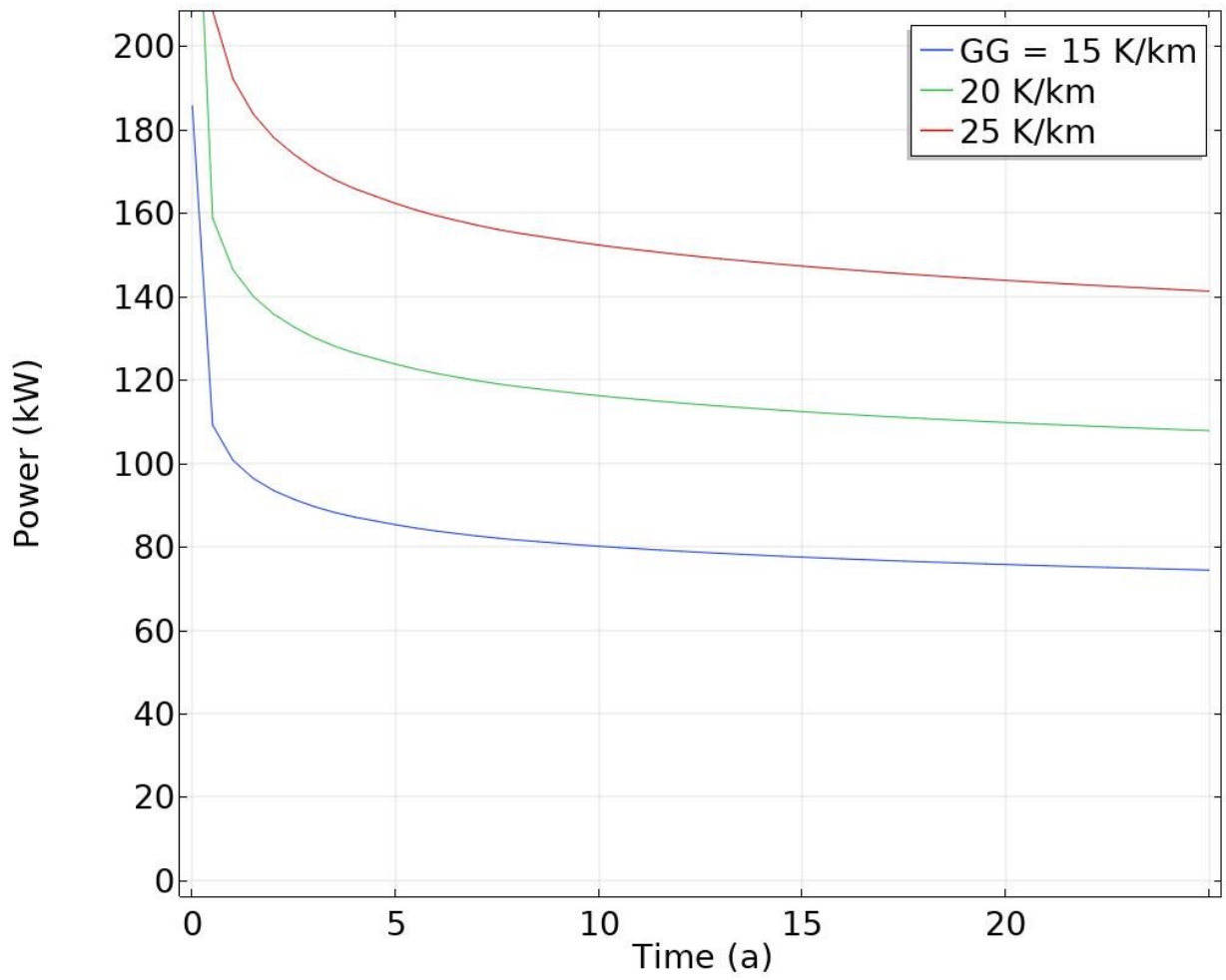

(a)

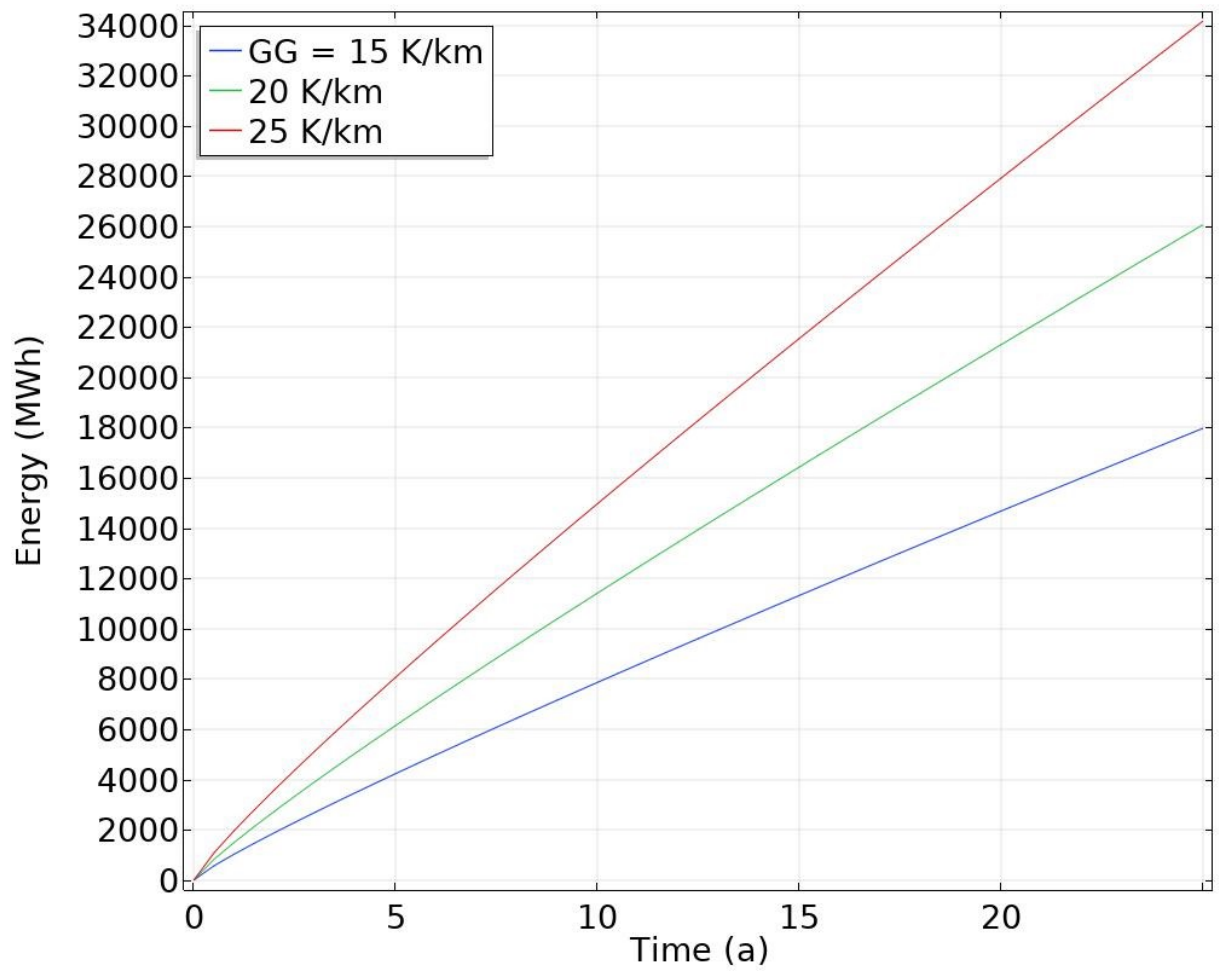

(b)

Figure 32. (a) Power and (b) accumulated extracted energy from a $2 \mathrm{~km}$ borehole with different geothermal gradients as a function of time. 
As second test, the thermal conductivity of the bedrock was varied, reflecting the effects of different rock properties. In reference case $\lambda=3 \mathrm{~W} / \mathrm{mK}$, which was varied by $\pm 0.5 \mathrm{~W} / \mathrm{mK}$, which could describe e.g. the effects of fractures and ground water in the rock (higher value) or very dense rock (lower value). Figure 33 summarizes the simulations.

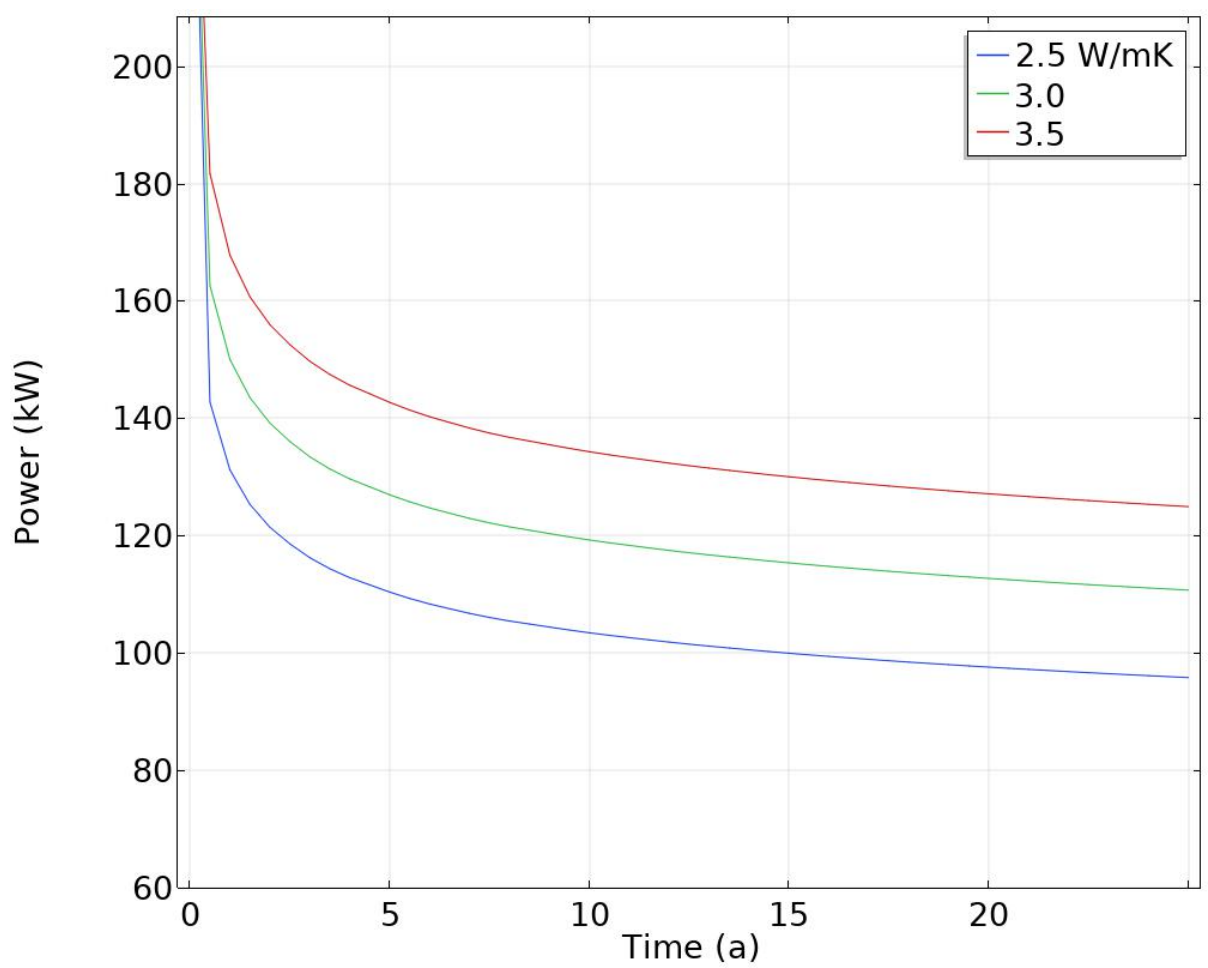

(a)

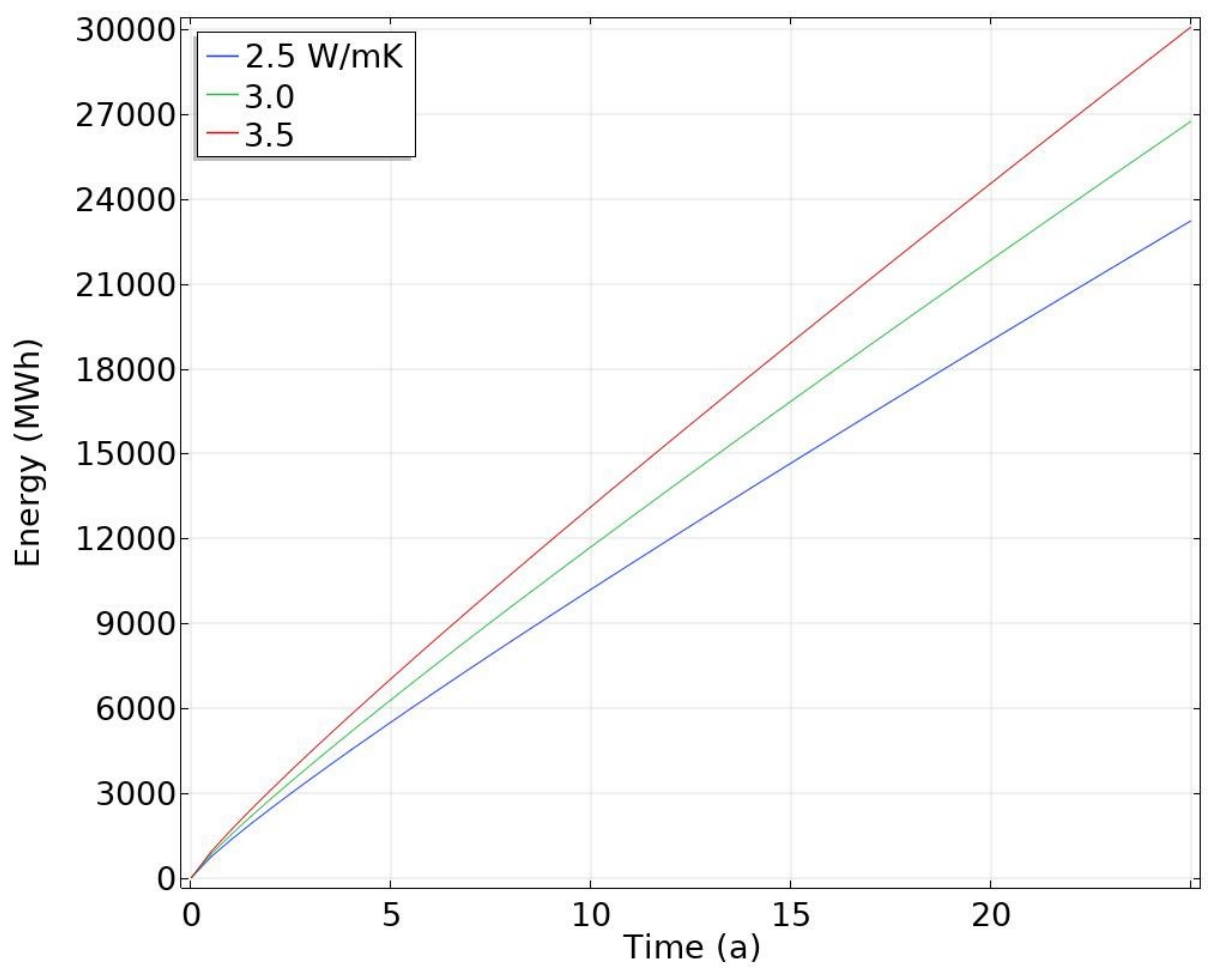

(b) 
Figure 33. (a) Power and (b) cumulative energy extracted from a $2 \mathrm{~km}$ deep-well with different bedrock thermal conductivity over time.

The results indicate that a $0.5 \mathrm{~W} / \mathrm{mK}$-units higher thermal conductivity leads to a $20 \%$ higher steady-state power. In extracted energy at $\mathrm{t}=25$ years, this would turn into a $15 \%$ higher yield. All in all, a higher thermal conductivity is preferable as that would increase the performance through better heat flow towards the borehole.

\subsection{Effect of some operational parameters}

In this section, the effect of operational parameters are investigated. Two parameters are of main interest, namely the mass flow rate and inlet temperature to the borehole, as both are key linking parameters to the heating system and heat pump.

Varying the mass flow rate $(\dot{m})$ will affect the power from the borehole $(\Phi)$, but also the outlet temperature $\left(T_{\text {out }}\right)$ through the following relation:

$$
\Phi=\dot{m} c_{p}\left(T_{\text {out }}-T_{\text {in }}\right)
$$

Thus, increasing the flow rate would increase the power, but reduce the outlet temperature and the $\Delta \mathrm{T}$, and vice versa if lowering the flow rate. Figure 34 shows how the power output, extracted heat and output temperature evolve over time with different flow rates.

The higher the flow rate, the higher the output power and extracted heat. However, the differences diminish at higher flow rates, e.g. in the range $6-10 \mathrm{~kg} / \mathrm{s}$ the differences are already small, meaning that increasing the mass flow beyond $6 \mathrm{~kg} / \mathrm{s}$ in this case would not provide much benefit. This is explained by the decreasing outlet temperature which starts to compensate for the linear growth of power versus mass flow rate. At very low flow rates, the outlet temperature could be doubled compared to the high flow rate values, but the power remains even at half from the highest values.

Increasing the mass flow rate to increase the power output will also increase the pressure losses according to Eq. (4). In Fig. 35, the pressure loss has been calculated for the different flow rate values. The pressure loss is proportional to the square of the flow velocity meaning that the pressure loss increases rapidly at high flow rates, as seen in Fig. 35. A higher pressure loss means a higher pumping power, which would in turn adversely affect the system COP. For example, with $6 \mathrm{~kg} / \mathrm{s}$ the pressure loss with a $2 \mathrm{~km}$ long pipe is $4.5 \mathrm{bar}$, which means in a continuous operation mode some $4.3 \mathrm{~kW}$ of pumping power, or $38 \mathrm{MWh}$ of electricity in a year, which would affect the system COP by ca $10 \%$. However, if moving to $10 \mathrm{~kg} / \mathrm{s}$, the pressure drop is 12 bar and the pumping power demand is almost 3-fold, but only $20 \%$ higher heat yield. The system COP could therefore drop by up to $16 \%$ (e.g. instead of 3.0 to 2.5). Therefore, it is important to optimize the mass flow rate not only against the thermal performance, but also accounting for the whole system performance. 


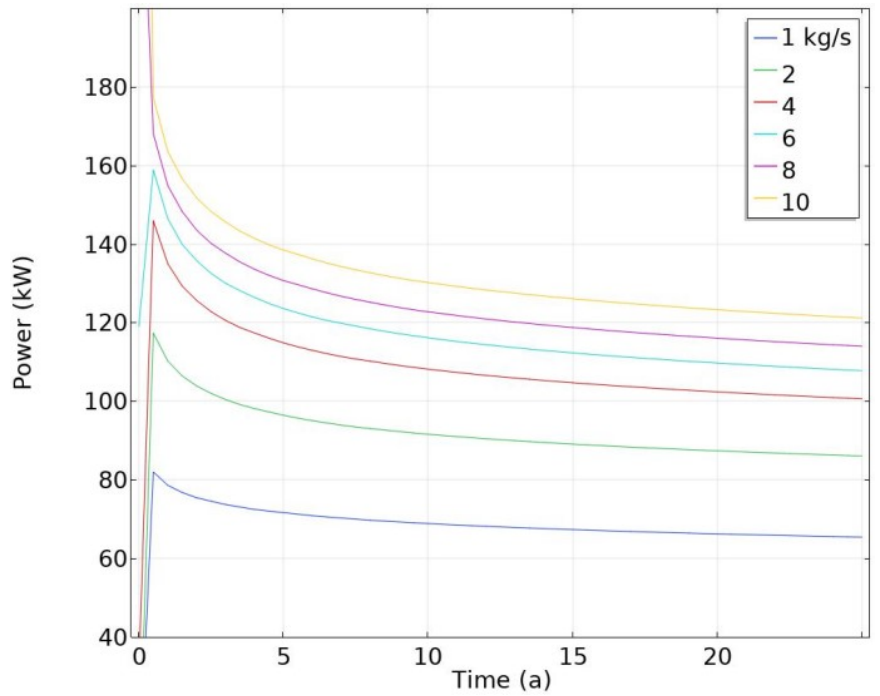

(a)

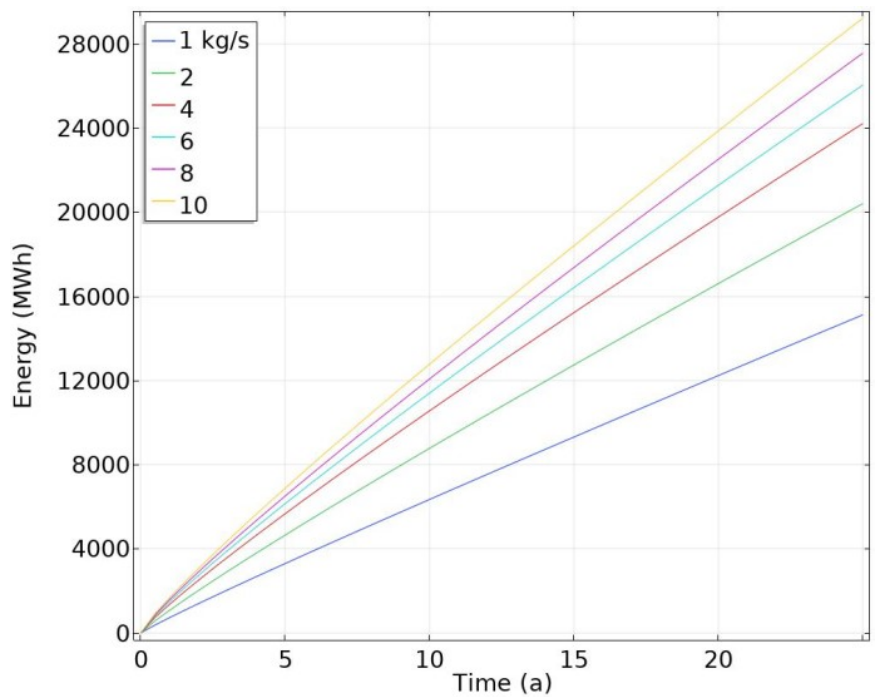

(b)

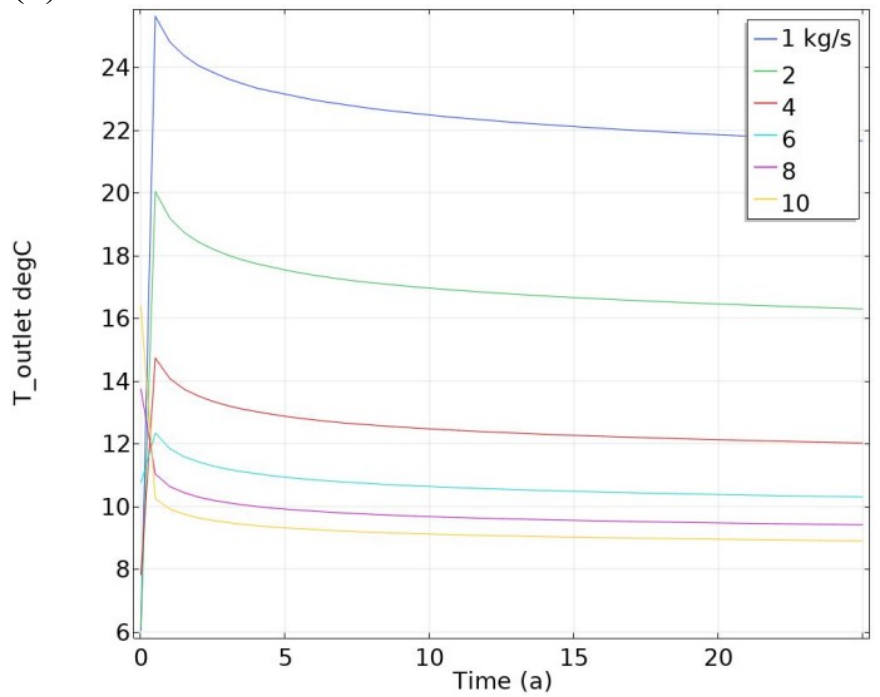

(c)

Figure 34. Effect on (a) power, (b) extracted energy, and (c) outlet temperature from the borehole with different flow rates. 


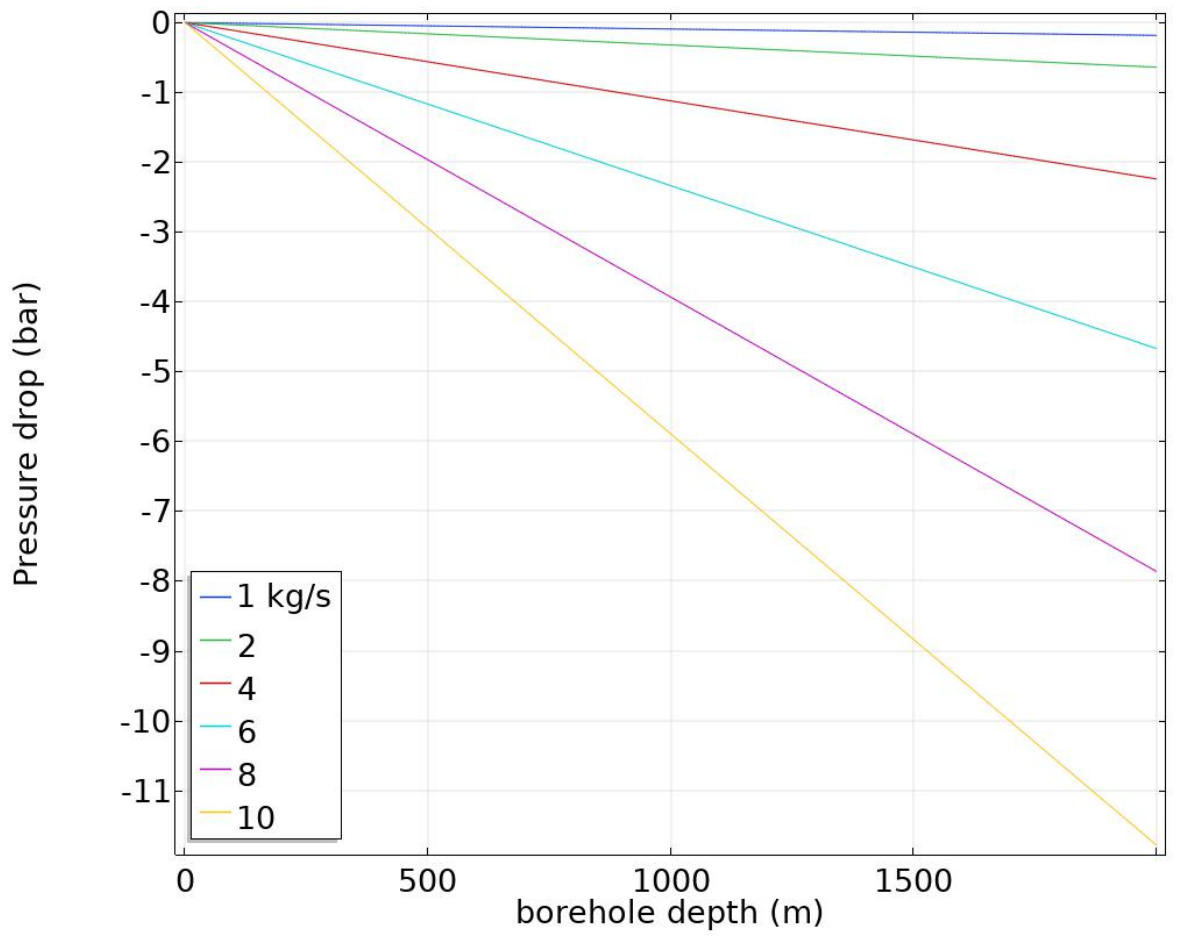

Figure 35. Pressure drop versus depth at different mass flow rates.

Next the effect of the inlet temperature on the performance of the reference system (Case \#1) was analyzed. This temperature is in practice the return temperature from the evaporator of the heat pump. Figure 36 summarizes the simulations when varying the inlet from 1 to 10 ${ }^{\circ} \mathrm{C}$. The cumulative heat extraction ( $\mathrm{t}=25$ years) and steady-state power is $70 \%$ higher in the $1{ }^{\circ} \mathrm{C}$ case compared to $10{ }^{\circ} \mathrm{C}$. Though the outlet temperature would be the lowest of the studied cases, the $\Delta \mathrm{T}$ would be the best (ca $5.5^{\circ} \mathrm{C}$ ), due to the better heat transfer. However, technically using $1{ }^{\circ} \mathrm{C}$ may be problematic due to the freezing danger, meaning that the circulation may need to be a closed system with an anti-freeze solution, which would make the system layout more complicated and costlier. Also, natural waters or ground water remain at $4-6{ }^{\circ} \mathrm{C}$ at lowest. 


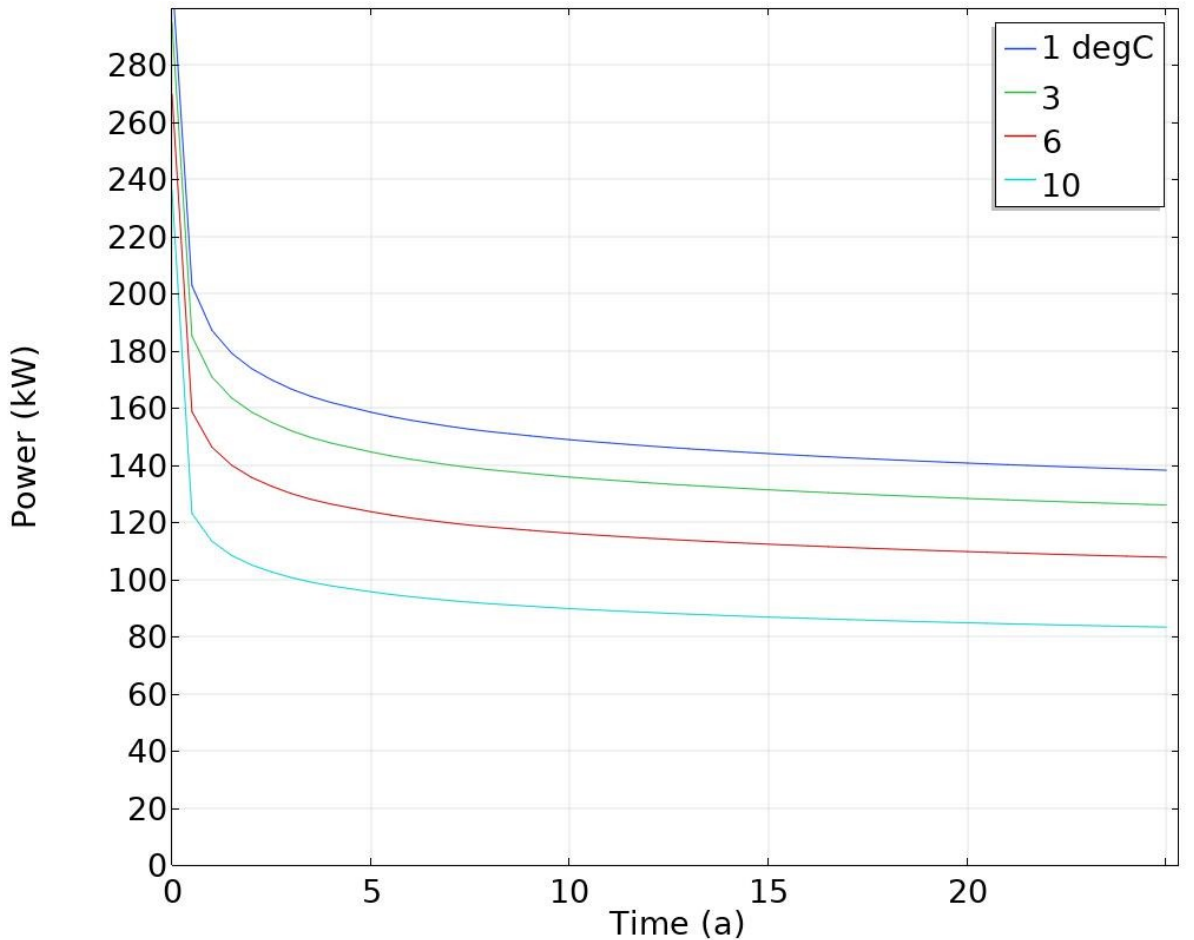

(a)

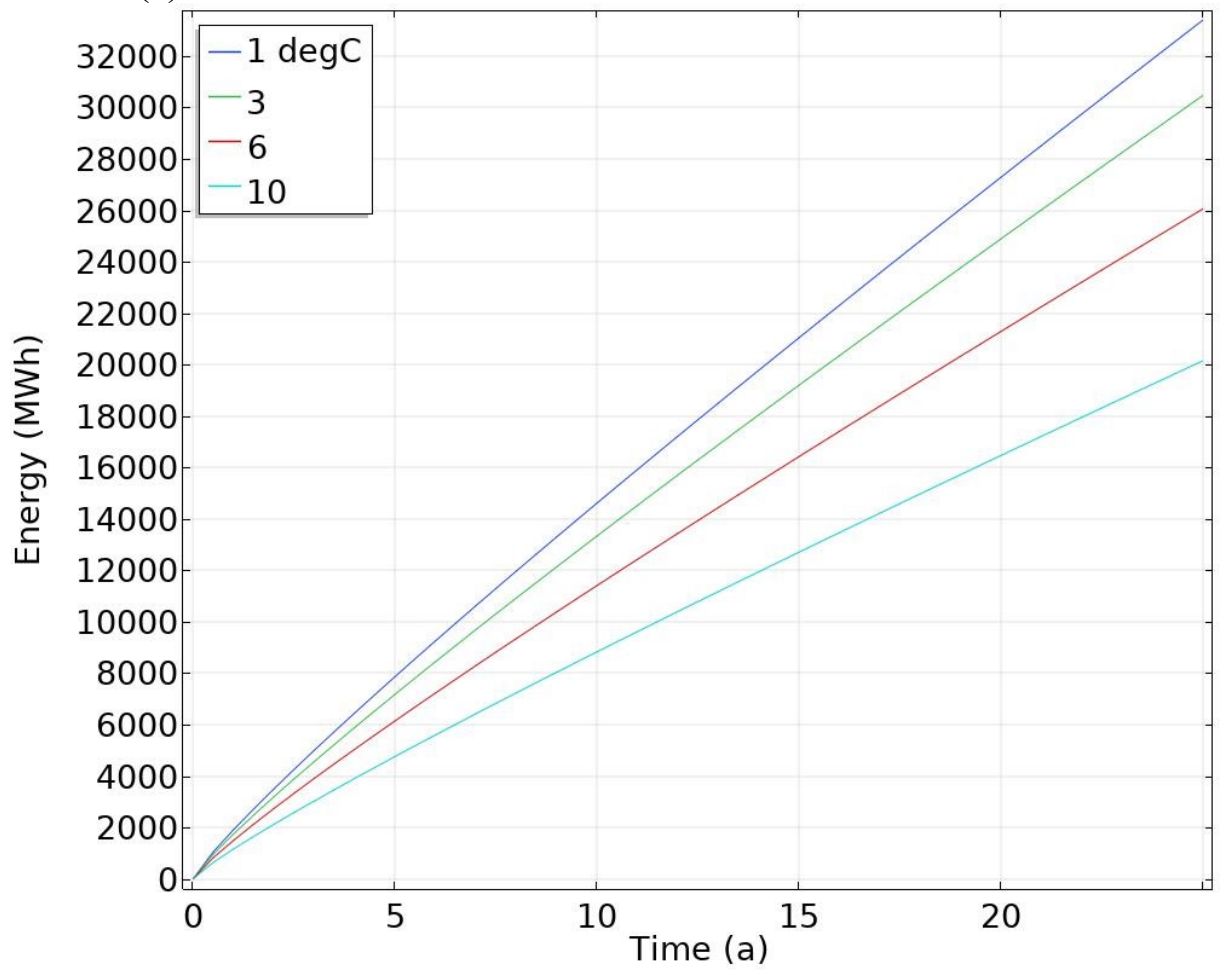

(b) 


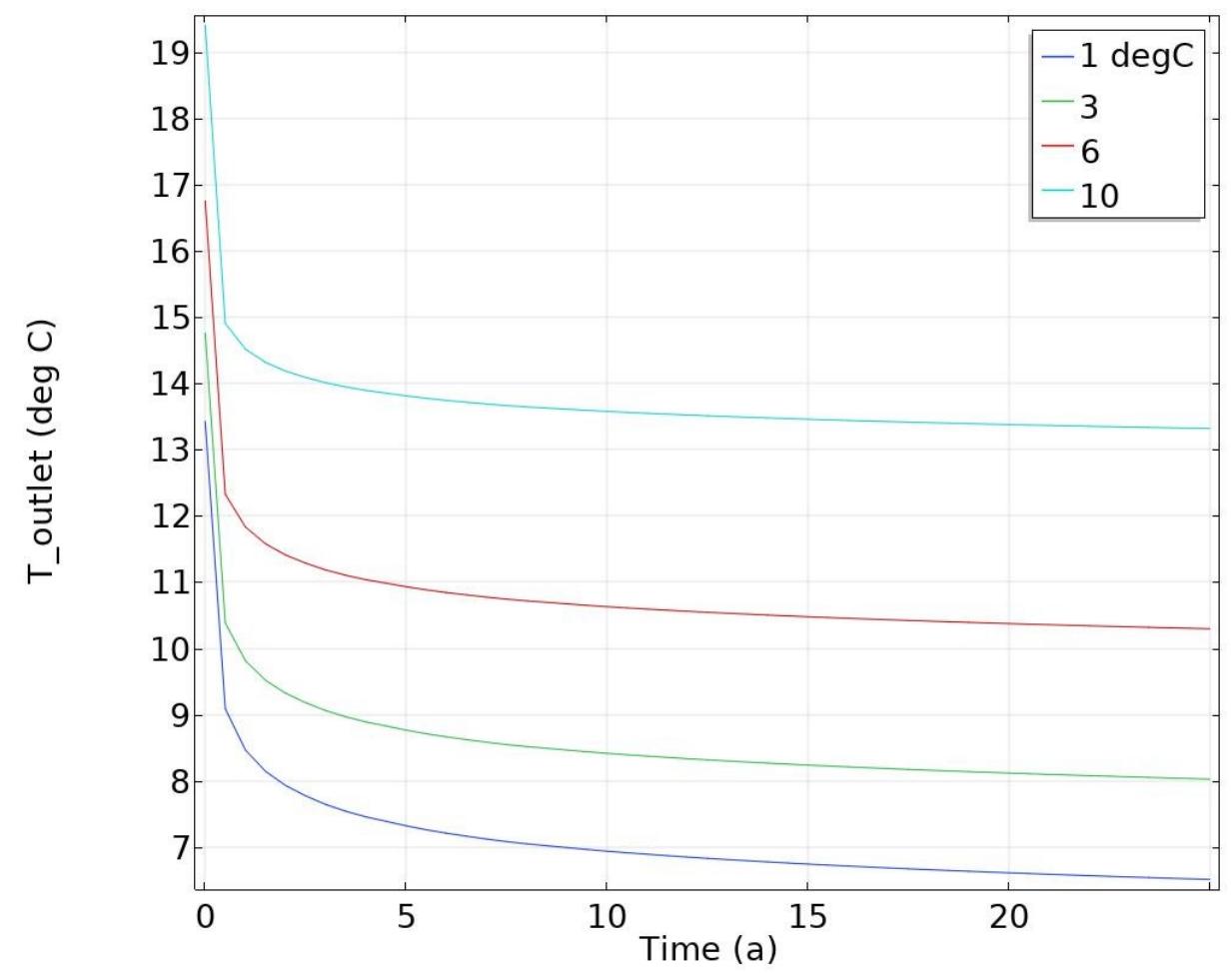

(c)

Figure 36. Effect of inlet temperature on (a) power output, (b) extracted heat, and (c) outlet temperature from a $2 \mathrm{~km}$ deep borehole.

\subsection{Effects of different operational strategies}

The reference case (Case \#1) represents a heat extraction strategy. The three other cases described previously include more sophisticated ways to operate the deep-well system. In the next, the possible benefits of these other operational strategies are investigated.

In Case \#2, the deep-well mode is operated in a cyclic way: 6 months discharging (with the same parameters as in Case \#1) followed by 6 months of non-operation recovery period to let the well replenish with heat flow from the surroundings.

In Case \#3, the deep-well mode is operated in a discharging-charging mode: 6 months discharging (with the same parameters as in Case \#1) followed by 6 months of heat injection at $39^{\circ} \mathrm{C}$. This case simulates using the deep-well as a heat storage as well, e.g. to store ambient or solar heat from the summertime. The charging is done at the same flow rate than the discharging.

Figure 37 summarizes the simulation outcomes with comparison to Case \#1. The cumulated heat extraction in Fig. 37 (d) indicates that the differences between the three strategies presented grow over time as expected. The best outcome is received with continuous extraction, which yields $25 \%$ more heat compared to Case \#3 with heat injection. The lowest amount of heat is received from the Case \#2 with the 6-month recovery period. However, when comparing the power outlet in Figs. 37 (a)-(c), after 10 years the extraction power in Case \#1 is ca 35\% lower than in Case \#2, and ca 70\% lower than in Case \#3 when approaching steady- 
state. During the first few years of operation, the difference are small as the heat content around the well is still ample. This observation may be important when integrating the deepwells into the building energy systems, which also need to consider the power levels.

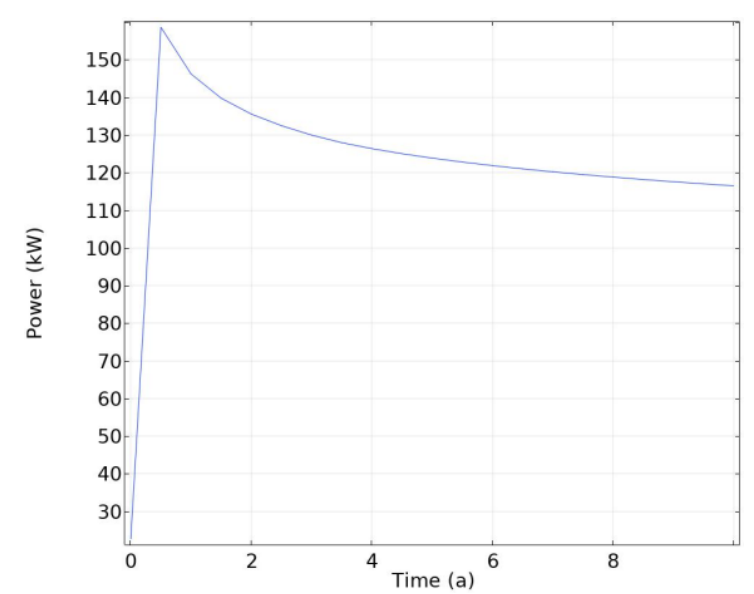

(a)

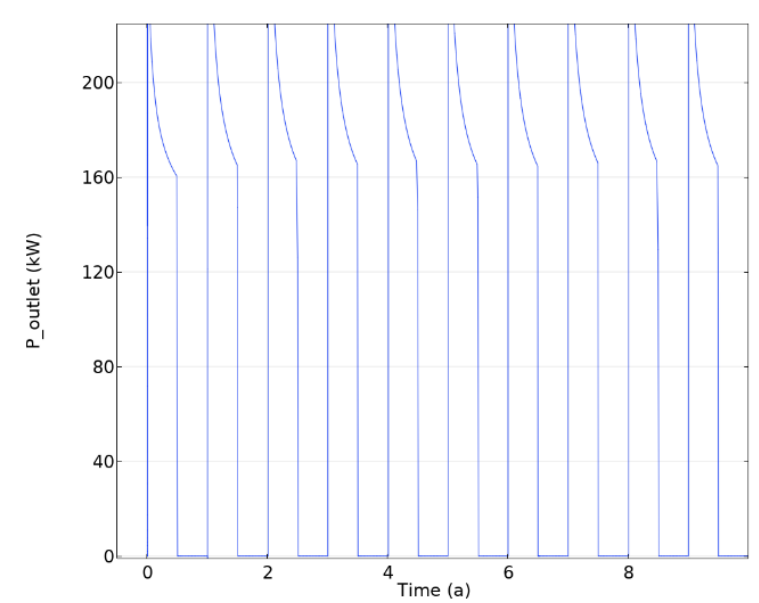

(c)

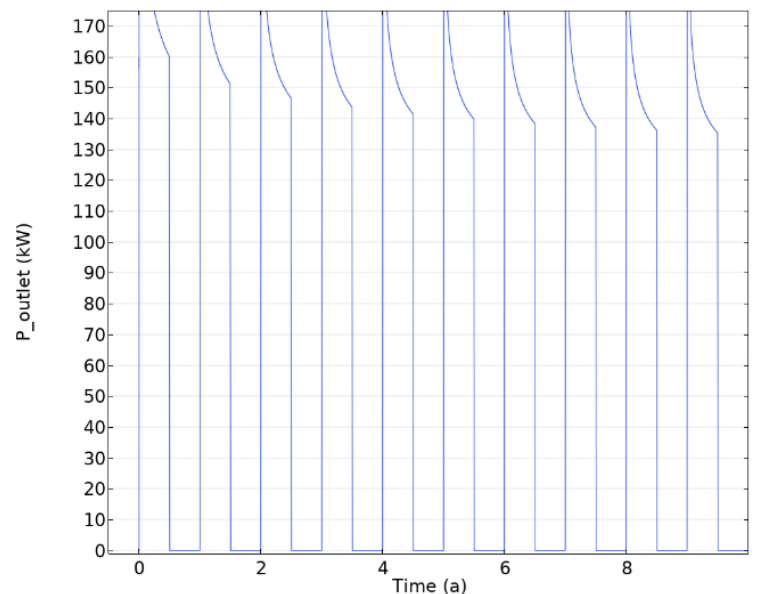

(b)

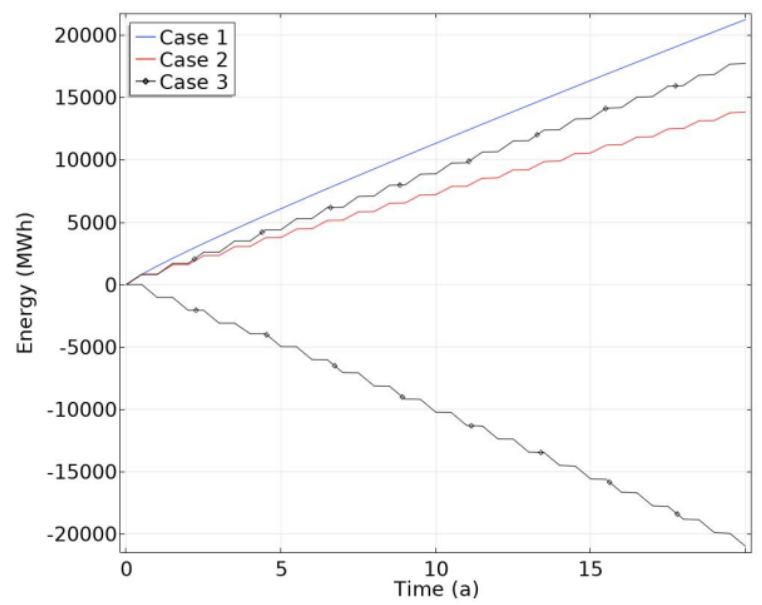

(d)

Figure 37. Comparison of three operational modes: power outlet for (a) Cases \#1, (b) \#2, and (c) \#3. (d) Cumulative heat energy for Cases \#1-\#3. Observe that the extraction of heat in Case \#1 is continuous (12 months/year), whereas in Case \#2 and \#3 it is 6 months/year.

As final case (Case \#4), a typical building or district heating application with the deep-well was simulated. Firstly, the power extraction level was scaled to correspond a typical district heating system, by using the district heating profile of Helsinki city, which was then matched to Case \#1 power levels so that the peak power corresponded to $120 \mathrm{~kW}$. Secondly, to provide a varying power output from the deep-well, the mass flow rate need to be varied, for which reason a proportional integral derivative (PID) feedback control function was incorporated to COMSOL. The PID controller combines proportional control with integral and derivative adjustments to compensate for changes in the system, i.e. in this case to provide the wanted power output by adjusting the mass flow rate. In practice, the PID involves proportional, integral, and derivate tuning. The principle of the PID is shown in Fig. 38. 


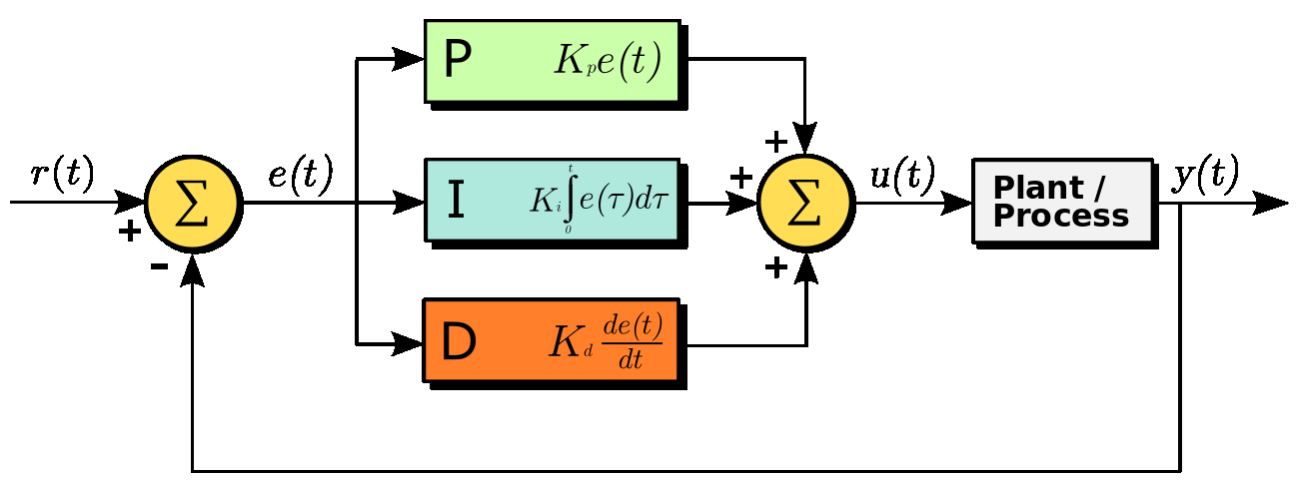

Figure 38. Principle of PID controller (Wikipedia, PID-Controller).

Mathematically, the PID controller is governed by (Åström, 2002):

$$
u(t)=k_{p} e(t)+k_{i} \int_{0}^{t} e(\tau) d \tau+k_{d} \frac{d e}{d t}
$$

where $\mathrm{u}$ is the control signal and $\mathrm{e}$ is the control error. The $\mathrm{k}_{\mathrm{i}}$ 's are proportional gains, i.e. tuning parameters.

Through parameterization, Eq. (28) can be written as

$$
u(t)=k_{p}\left(e(t)+\frac{1}{T_{i}} \int_{0}^{t} e(\tau) d \tau+T_{d} \frac{d e(t)}{d t}\right)
$$

where $T_{i}$ is the integral time constant and $T_{d}$ the derivative time constant. In the present work and case, the best parameter values were found to be $\mathrm{k}_{\mathrm{p}}=2, \mathrm{k}_{\mathrm{i}}=0.1, \mathrm{k}_{\mathrm{d}}=0$, meaning that the PID reduced to a PI controller in this case.

Figure 39 shows the simulation results with the PID-controller with varying heat demand, one with max $120 \mathrm{~kW}$ and another with double power output. The results are shown for a 2000 -day period corresponding to almost 6 years. The mass flow rate with the lower power is still acceptable, but when doubling, the flow rates increase even up to 10-15-fold which could cause major pressure losses and increasing pumping energy demand, but the heat delivery would still work. The higher power output would also lead to lower outlet temperature from the borehole.

The outlet temperature variation with the lower power demand varies during one operational year about $7{ }^{\circ} \mathrm{C}$ (last cycle average $21{ }^{\circ} \mathrm{C}$ ), with the higher power demand this would be almost double (last cycle average $14.5^{\circ} \mathrm{C}$ ), meaning also a lower heat pump COP. Thus, a too high heat extraction rate would have double (negative) effect on the COP: through higher pressure losses and lower fluid outlet temperature. 


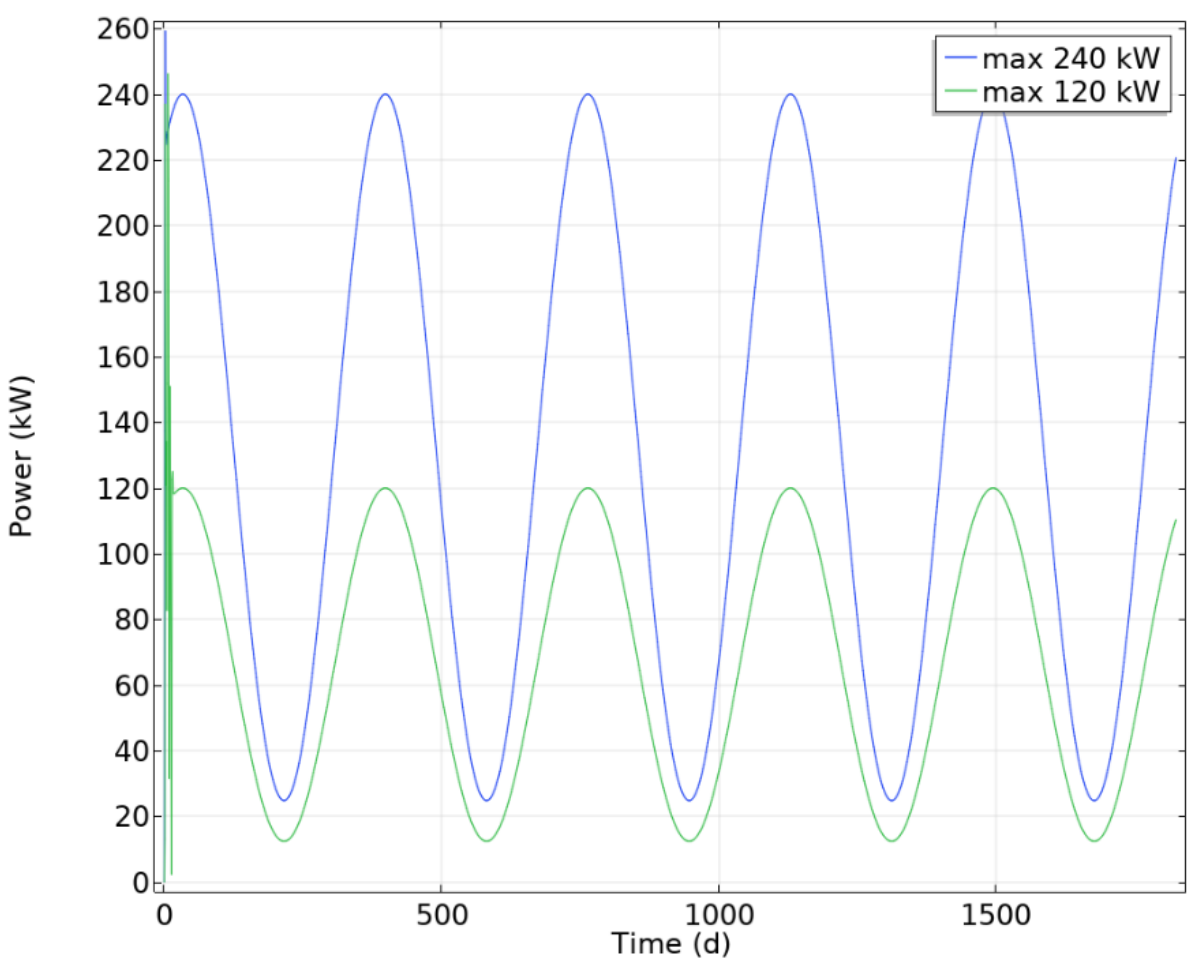

(a)

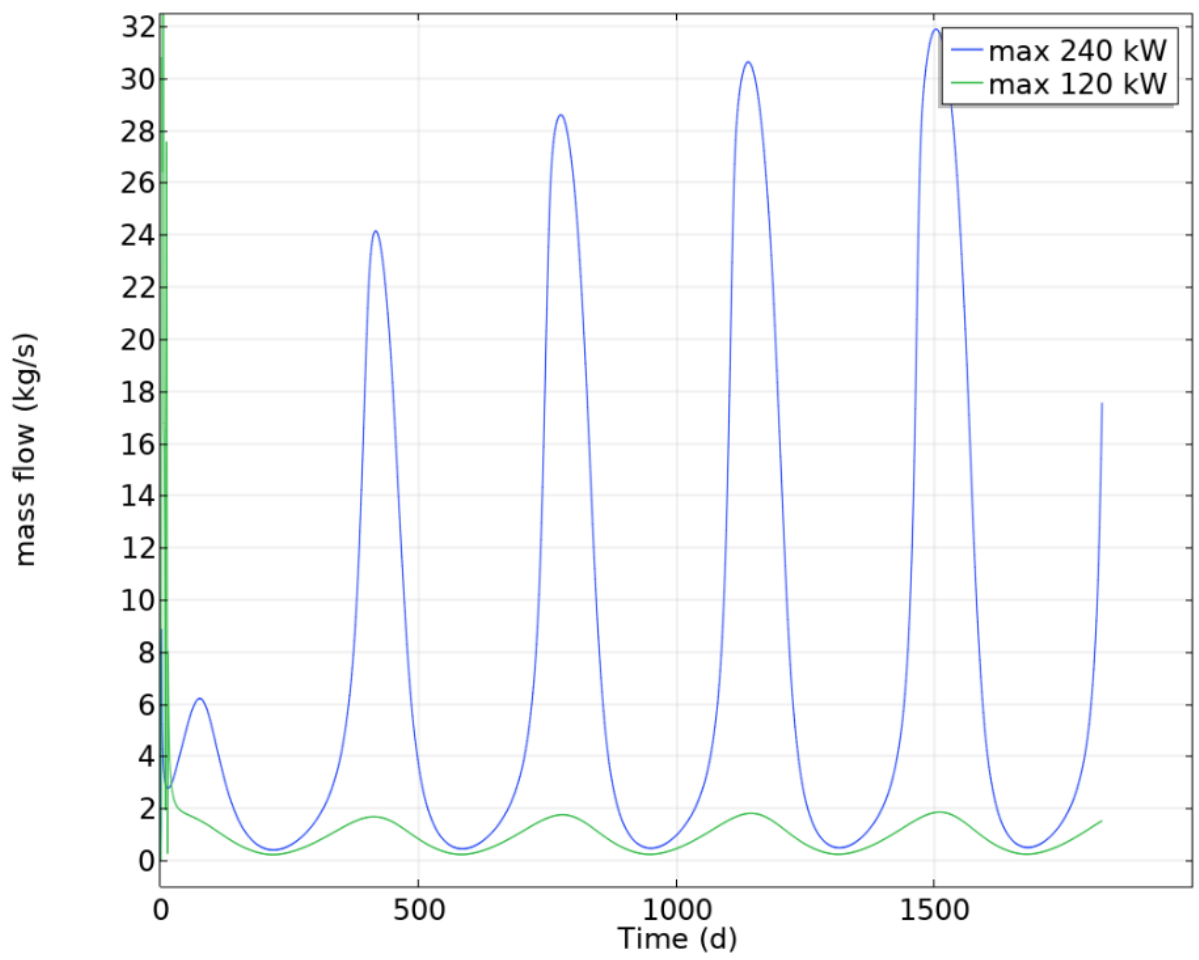

(b) 


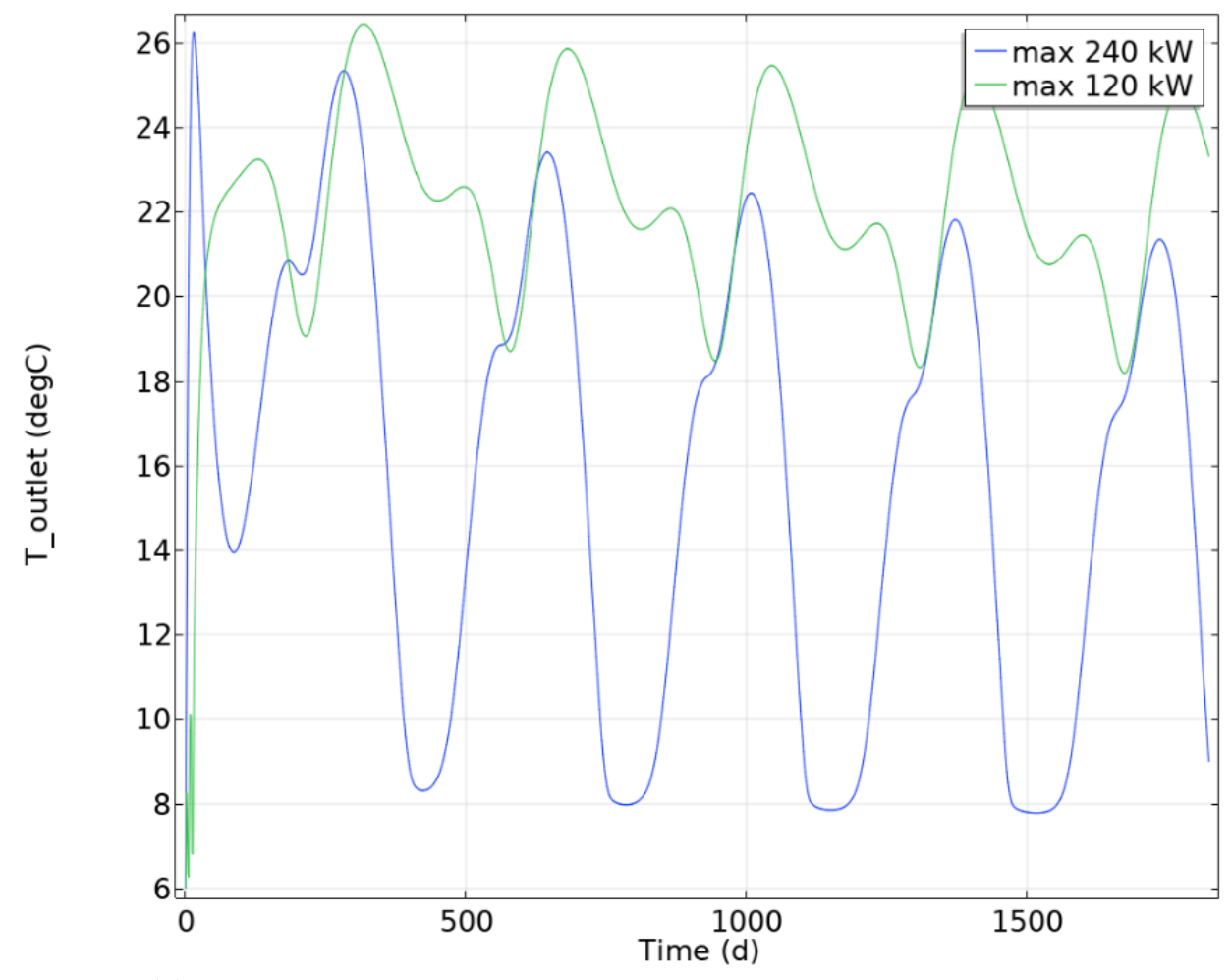

(c)

Figure 39. Borehole performance with PID-controller linked to a hypothetical building or district heating application. (a) Power demand, (b) mass flow rate in borehole, (c) outlet temperature from borehole.

\subsection{Short heat pulse injection}

As a special case of Case \#3, the dynamics of the deep-heat well system was also investigated with injection of heat pulses of short duration. This kind of situation could occur if the deepheat system were connected to so-called power-to-heat $(\mathrm{P} 2 \mathrm{H})$ conversion, which utilize surplus electricity from variable electricity production such as wind power or solar photovoltaics (Lund et al., 2019). In this case the deep-heat system would function as a heat storage for $\mathrm{P} 2 \mathrm{H}$, or, $\mathrm{P} 2 \mathrm{H}$ could regenerate the rock if extraction has continued for a long time. In this way a deep-heat system could also add flexibility to the power system by offering a drain for surplus electricity.

In a $\mathrm{P} 2 \mathrm{H}$-coupling when charging occurs, one may assume that the price of electricity is very low, meaning that even though more pumping power may be needed, the running costs may not increase. For the heat pump, this would most likely mean a higher COP as the outlet temperature would be higher than without the $\mathrm{P} 2 \mathrm{H}$, though the real improvement in COP will very much depend on the operational conditions and available $\mathrm{P} 2 \mathrm{H}$ heat, which could also vary very much from year to year.

In the next, a few test cases were simulated in order to analyze how the deep-heat system could absorb such sudden heat pulses and how that heat would improve the total extracted heat and outlet temperature of fluid from the borehole during extraction. 
In Fig. 40, we show how a heat injection would be absorbed over 6 months with different input temperatures, when starting with undisturbed rock temperature. The heat flow from $\mathrm{t}=0.05 \mathrm{a}$ (18 days) onwards is shown. In the beginning ( $\mathrm{t}>18$ days), the borehole could absorb up to close to $0.9 \mathrm{MW}$ of power at $90{ }^{\circ} \mathrm{C}$, but the heat flow to the rock starts to stabilize after some months as the heat transfer and thermal conductivity of rock will limit the absorption of heat. At $\mathrm{t}=6$ months, $70-75 \%$ of the original value is reached. Lowering the injection temperature clearly drops the performance, e.g. with $40{ }^{\circ} \mathrm{C}$ the injection power drops by more than $70 \%$ compared to $90{ }^{\circ} \mathrm{C}$. Recalling, that in Case \#1 with continuous heat extraction, steady-state output power will approach $100-120 \mathrm{~kW}$, the injection power is 5-6-fold with $\mathrm{T}=90{ }^{\circ} \mathrm{C}$, with $\mathrm{T}=40{ }^{\circ} \mathrm{C}$ it is still $40-50 \%$ higher. This test run demonstrates that the deep-heat well could also function as a high power sink for $\mathrm{P} 2 \mathrm{H}$.

If the charging time becomes long and available heat varies strongly, utilizing a separate water storage as buffer to even out peaks in $\mathrm{P} 2 \mathrm{H}$ power and charging the rock with more continuous power could also be a solution.

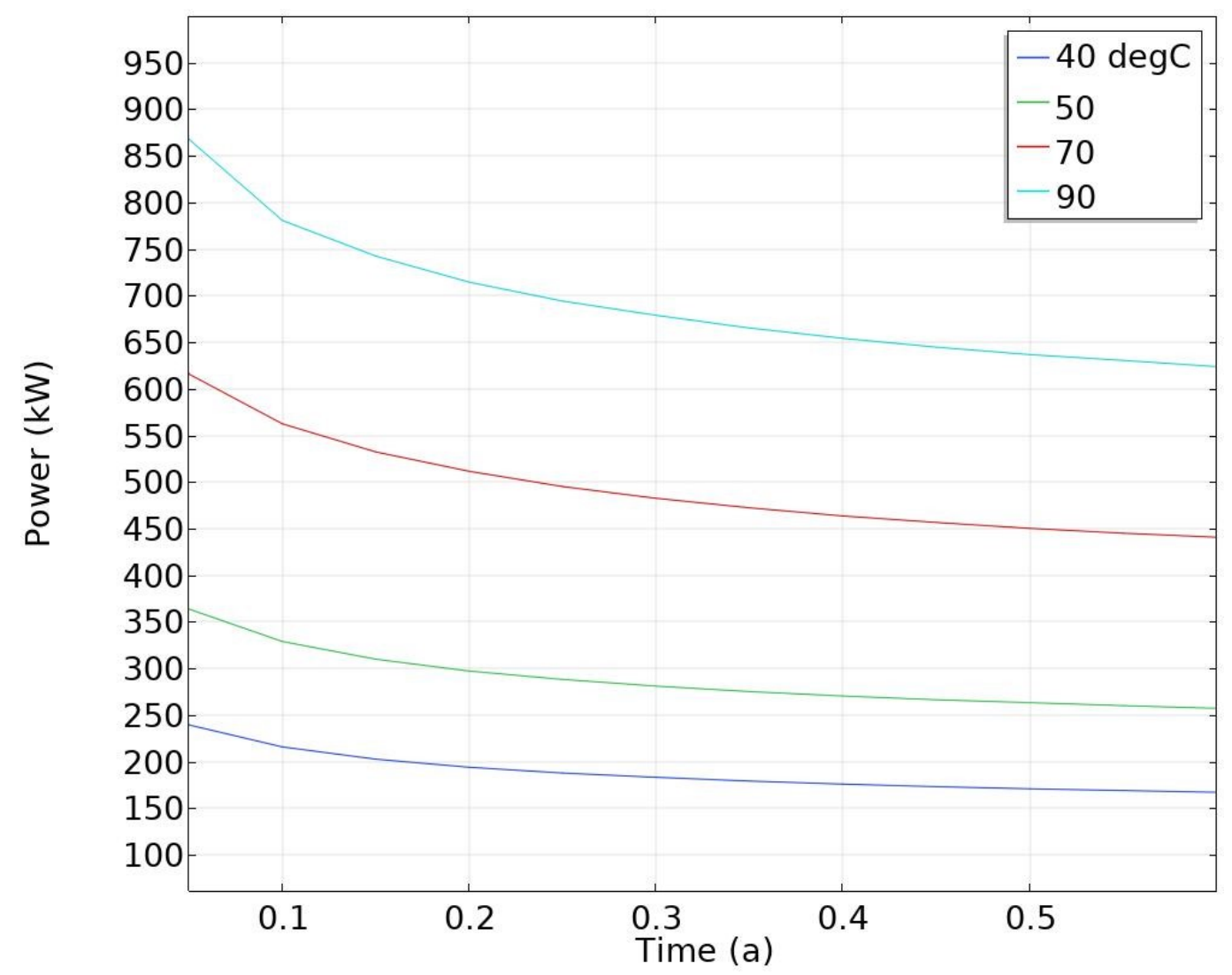

Figure 40. Heat injection from borehole into rock with different fluid inlet temperatures. The parameters correspond to Case \#1.

To assess the value of such shorter 'heat pulses', the following hypothetical sequence was simulated: 1 month heat injection at $70{ }^{\circ} \mathrm{C}, 1$ month pause, and 6 months of heat extraction (as in Case \#1). This was compared to a sequence of 2 months pause and 6 months heat extraction. Figure 41 summarizes the outcome. 


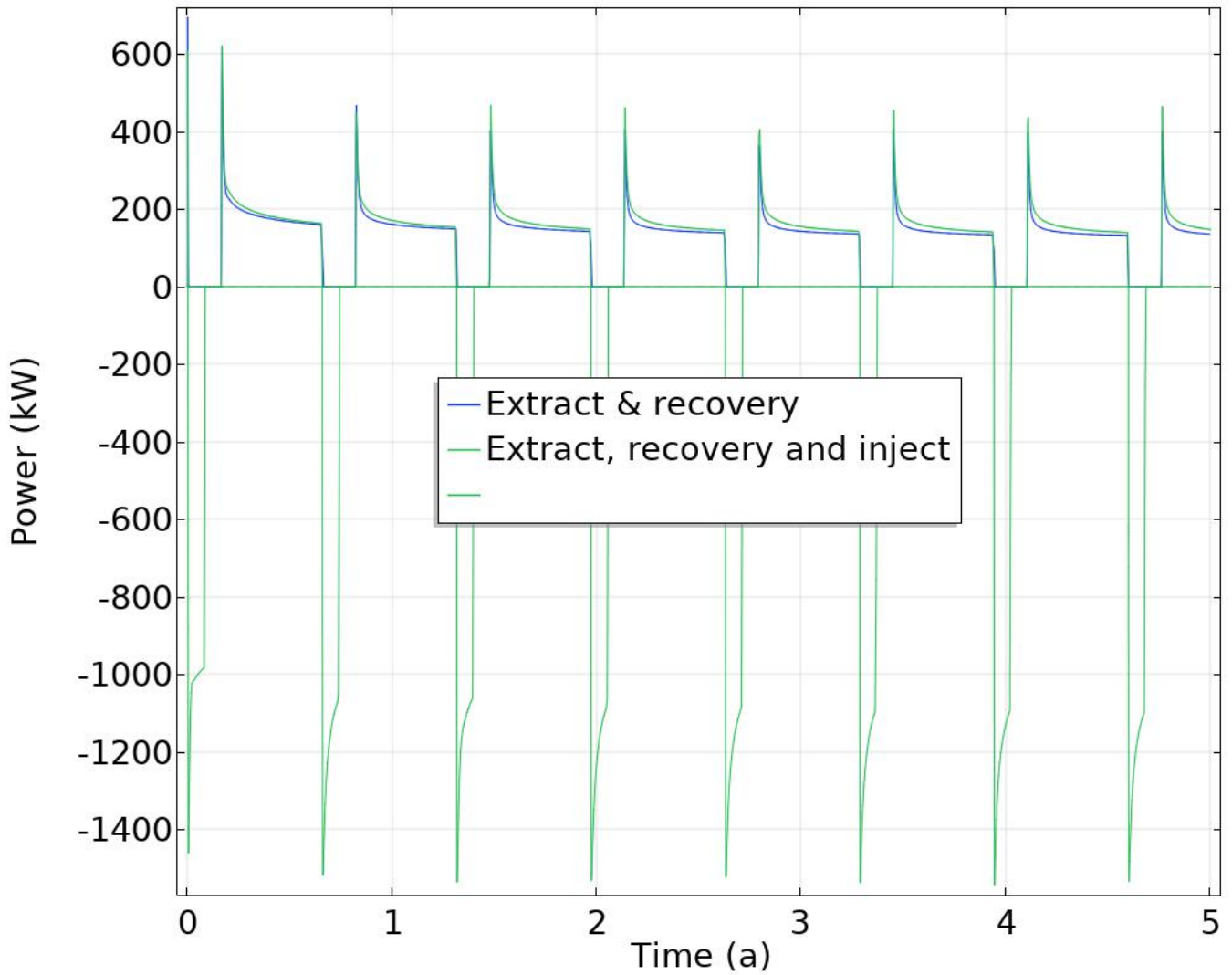

(a)

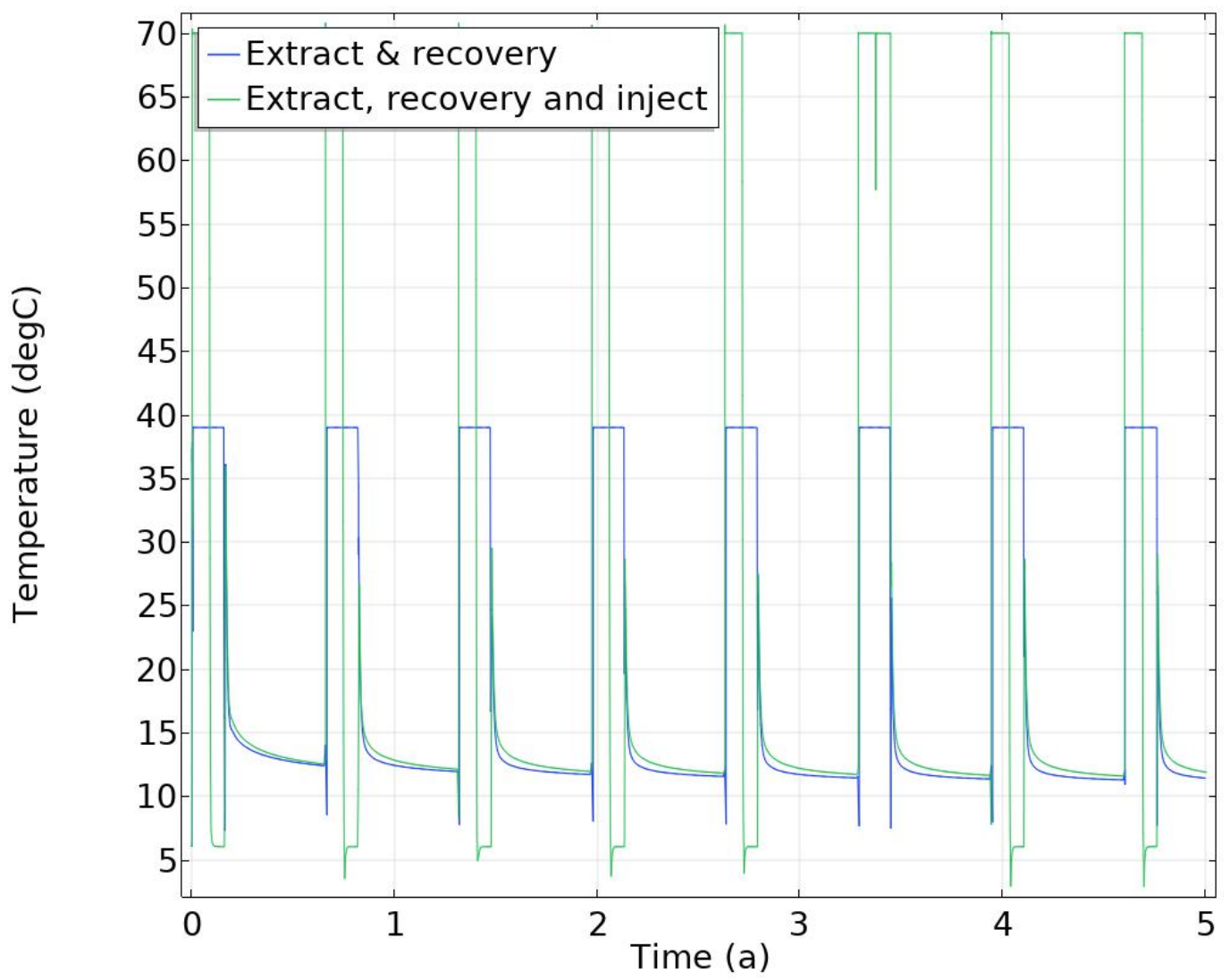

(b) 


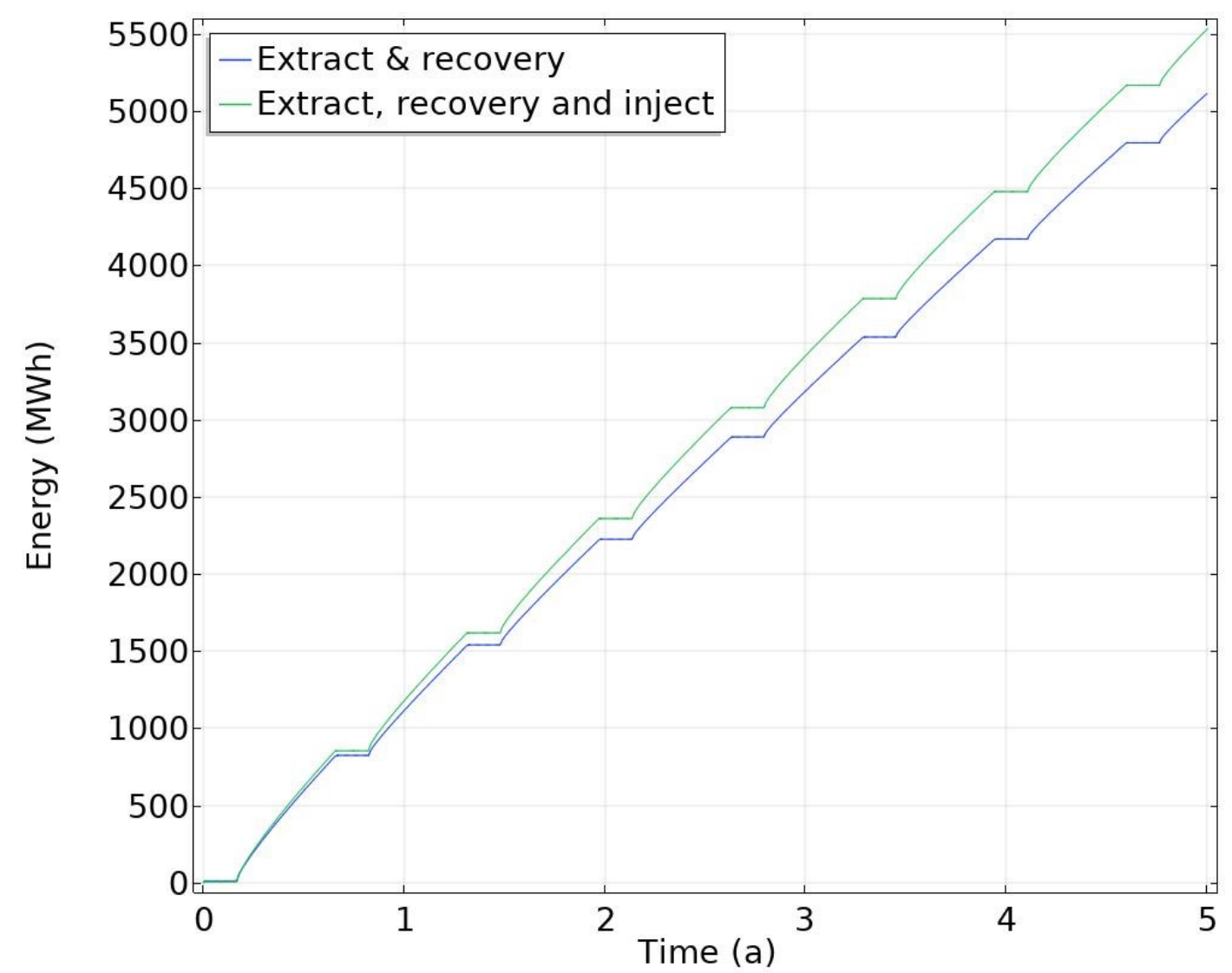

(c)

Figure 41. Analysis of effects of short 1-month injection of heat on deep-heat well performance. Parameters as for Case \#1. Temperature of heat injection is $70{ }^{\circ} \mathrm{C}$. (a) Power, (b) outlet temperature from borehole, (c) cumulative heat energy from borehole.

From Fig. 41, one can see that the heat injection improves the performance of the well. Viewing the situation in the period 4-5 years, when the well is approaching the quasi steadystate conditions, the heat injection increases the output power by about $10 \%$ at the beginning of the extraction, but the difference drops to some per cents at the end of the extraction. The output temperature of the fluid is ca $5{ }^{\circ} \mathrm{C}$ higher, when heat extraction starts, but the difference reduces to ca $0.5{ }^{\circ} \mathrm{C}$ at the end of the 6 -month period. The higher temperature would also mean a slightly higher COP for the heat pump operation. Figure 41 (c) indicates a small energy benefit for the heat injection case which accumulates over each cycle. The heat power rate at the start of injection is quite high above $1 \mathrm{MW}$ and remains relatively high as the injection period is short (1 month).

Though the case above is only intended to demonstrate the effects of a short heat injection, it clearly illustrates that even shorter heat injection such as from $\mathrm{P} 2 \mathrm{H}$ could provide benefits for the deep-heat well system. 


\subsection{N-hole system}

A single deep-heat well can typically produce heat at steady-state above $100 \mathrm{~kW}$ during continuous extraction. To increase the power output, several boreholes could be used. Here, we investigated the combined effects of a group of deep-wells. The wells were grouped 30 meters apart in the following configurations:

- 2 wells: 1 x 1

- 4 wells: $2 \times 2$

- 8 wells: 2 x 4

- 16 wells: 4 x 4

Each well were operated as Case \#1. The combined effect with N-wells is shown in Fig. 42.

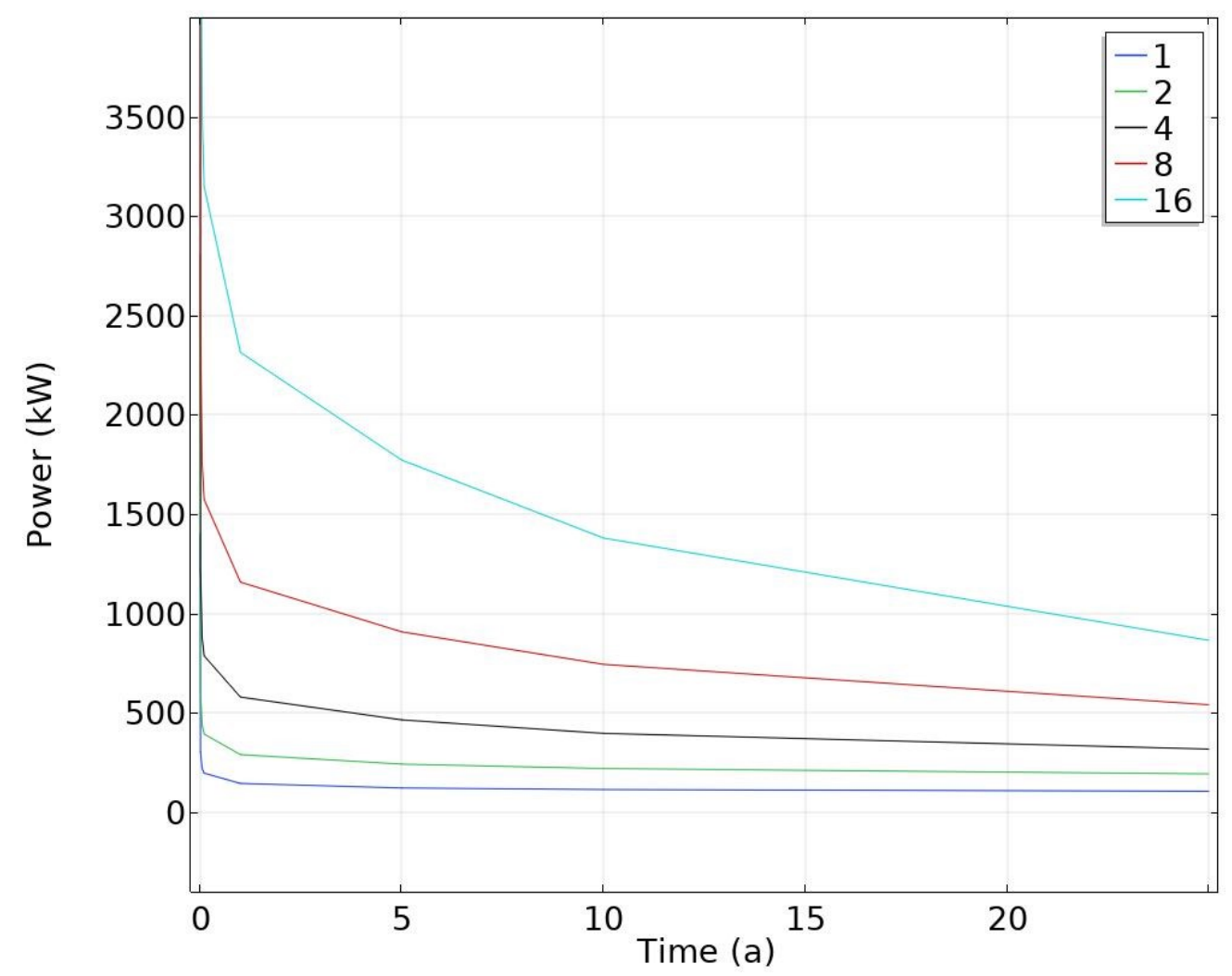

(a) 


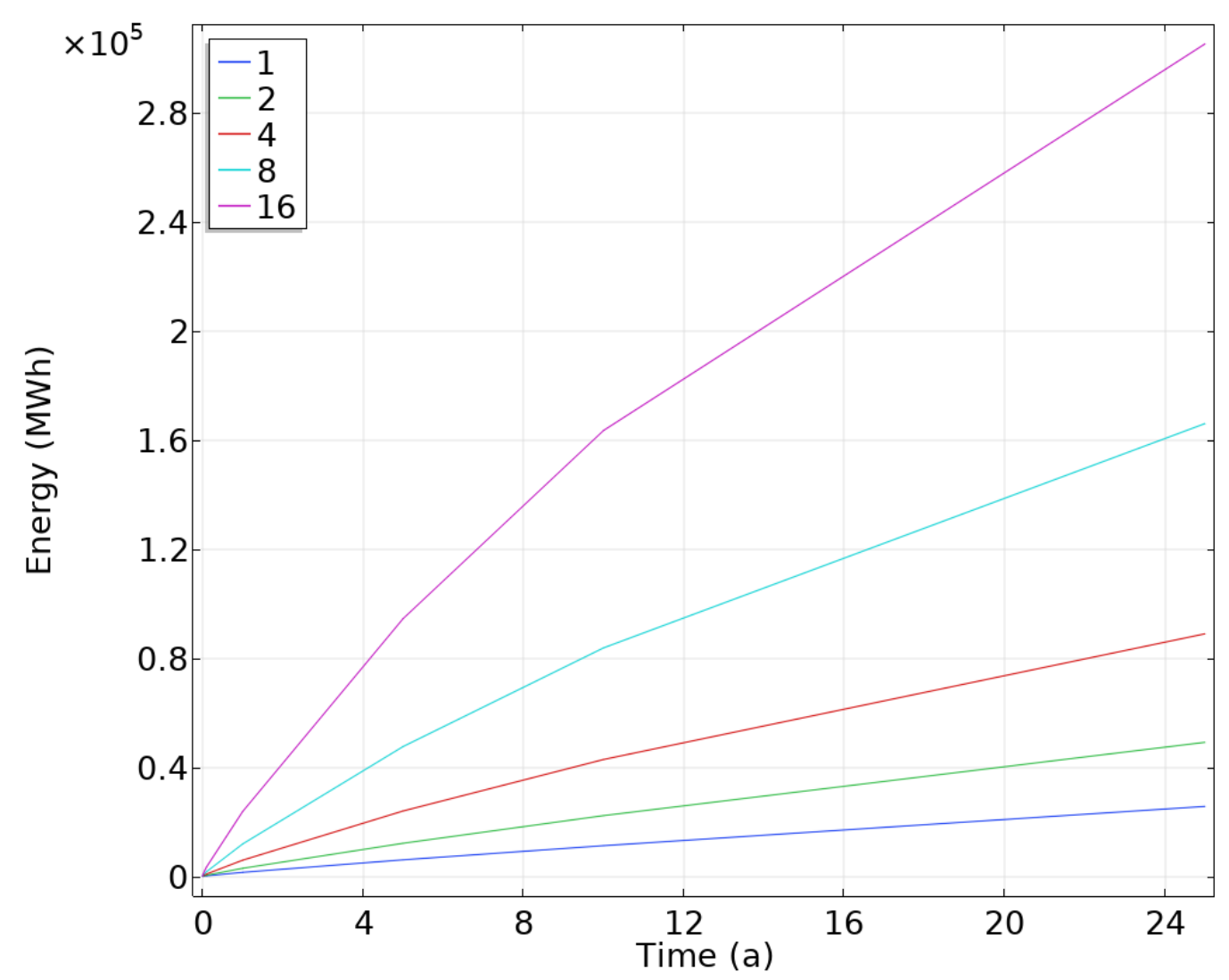

(b)

Figure 42. Combined (a) power and (b) cumulative extracted heat from N-hole configuration over time.

Figure 42 clearly shows that the output power declines quicker with several wholes $(8,16)$ over time, whereas the output is steadier with fewer holes $(1,2,4)$, due to higher total heat extraction from rock and the 'slowness' of heat replenishment from the surroundings limited by the thermal conductivity. For example, at $\mathrm{t}=25$ years a single well would yield around $110 \mathrm{~kW}$ heat, but with 16 holes the output drops to one half per hole, or $55 \mathrm{~kW} /$ hole. The accumulated heat extraction would be $25 \%$ lower; with 4 wells $13 \%$ less than with one hole; with 2 holes the difference is $4 \%$ only. Thus, the simulation indicates a deep-heat system with a few adjacent holes $30 \mathrm{~m}$ apart works thermally satisfactorily, but with more wells, the overall thermal performance is clearly lower per well, which may require larger distances between the wells. 


\section{Conclusions}

The aim of this thesis was to investigate the feasibility of deep wells in rock as heat source for heat pumps in Finnish conditions. The main approach used was thermal analysis of deepheat wells, mainly for assessing the performance under different conditions and physical parameter variations. For this purpose, a mathematical model for deep-heat wells was built using the COMSOL Multiphysics software. A comprehensive literature review preceded the modelling and simulation parts of the work. The model was successfully verified against previous modelling work.

The simulation results show that the performance of a deep well is influenced by several factors such as the properties of the rock, structure of the borehole heat exchanger, fluid flow conditions in the borehole, and operational strategies, among others. The variation of the performance of the well against the range of the possible parameter values is large, which emphasizes careful site investigation, thermal analysis, and pre-design before constructing such systems.

The reference system chosen for analysis was a $2 \mathrm{~km}$ deep well with a vacuum tube-type of borehole heat exchanger in typical Finnish bedrock. When using for continuous heat extraction, the steady-state output would settle after some 5 years of operation at approximately $110 \mathrm{~kW}$, i.e. $55 \mathrm{~W} / \mathrm{m}$. The outlet temperature of the circulating fluid would be at approximately $10{ }^{\circ} \mathrm{C}$ when the inlet is set at $6{ }^{\circ} \mathrm{C}$. Compared to a traditional $300 \mathrm{~m}$ borehole used in a heat pump system, the $2 \mathrm{~km}$ hole would give 30 -fold higher heat energy output a year, but this is a somewhat conservative estimate as a continuous heat extraction mode was employed in the deep-heat well case. The output of the well could still be increased if the inlet temperature were decreased, but this imposes always higher risks for freezing. For example, halving the inlet temperature to $3{ }^{\circ} \mathrm{C}$ could increase the cumulative heat extracted by almost $20 \%$ after 25 years of operation. But this would also drop the steady-state outlet temperature by $2.5^{\circ} \mathrm{C}$, which worsens the COP of the heat pump.

The above heat output value was achieved with a flow rate of $6 \mathrm{~kg} / \mathrm{s}$, but exceeding this value would not provide notable benefits. The mass flow also affects the pumping power of the well, and could in this case affect the COP of the heat pump system by about $10 \%$. With 10 $\mathrm{kg} / \mathrm{s}$, the heat yield would increase by $20 \%$, but the pumping power would be 3 -fold and drop the COP by $16 \%$. Considering the parasitic electricity use in pumps as part of the COP of the whole system is therefore an important part of the design of a deep-heat well to avoid unnecessary losses.

This kind of interplay between the inlet temperature, mass flow rate, outlet temperature, amount of heat extracted, and heat pump performance would be typical for a deep-heat well system. There are strong feedbacks, interactions, and interlinks involved, for which reason the design of such systems will require careful analysis of the whole system to find the best configuration. For example striving to maximize the amount of extracted heat energy from the well, would need higher flow rates which increases the pumping need and reduces the system COP. At the same time, the outlet temperature of the fluid from the borehole would decrease, thus also decreasing the COP of the heat pump. Therefore, trying to find a tradeoff between the different parameter values would be important to find the optimum performance point of the system. 
Employing a vacuum-tube as the borehole heat exchanger solution was motivated by avoiding thermal short-circuiting between the inner and outer pipes in the borehole if using e.g. plastic pipes. Short-circuiting in plastic pipes would be particularly strong at low flow rates or with increased pipe thermal conductivity. If employing a polyethylene pipe in a deep-heat well and a low flow rate, the power output from the well could drop by even $50 \%$.

A deep-heat well system could be operated in many ways. The simplest strategy is heat extraction, which could be continuous or periodic with a recovery period to allow replenishing of well with heat from surrounding heat. The well could also be directly linked to the heat pump system through a PID controller which regulates the mass flow rate to fit the heat demand. By reversing the circulation, heat could also be injected to the well to heat up the rock for later use, i.e. using the rock as a kind of heat storage. In case of heat injection over shorter periods, quite high charging power levels could be reached, even around $1 \mathrm{MW}$ for a single hole, which could enable coupling of the deep-heat well e.g. to power-to-heat schemes.

The benefits or mutual performance ranking of the operating strategies depend very much on the conditions and assumptions, for which reason making very long-ranging conclusions may not be appropriate. In terms of power output, a recovery period or a heat injection period between the heat extraction would guarantee higher output power levels during the heat extraction period. However, any halt in heat extraction would also halt the accumulation of extracted heat, meaning that the continuous heat extraction mode would rank high when only the cumulative heat extraction is measured.

The geothermal gradient and the thermal conductivity of the rock have a major impact on the performance, emphasizing investigation of geophysical parameters prior to building a deep-heat well. Higher thermal conductivity of the bedrock increases both the output power and energy yield of the borehole heat exchanger. A less than $20 \%$ increase in thermal conductivity would raise the steady-state power output by $20 \%$. A higher thermal gradient of the ground also increases performance. A $25 \%$ increase from the reference value used would lead to a $30 \%$ energy yield over a 25 years extraction period of heat.

The heat delivery of a deep-heat well can be adjusted to some extent through varying the mass flow rate or the inlet temperature of the fluid. In cases the control range is not enough, additional wells could be constructed, though this could compromise the idea of deep-heat wells as a space saving solution. Adding several wells will cause interference between the wells reducing the power output and energy yield per well. With a large 16-well system, the output power could drop to half per well compared to a single-well system, and the unit-well cumulative heat extraction by $25 \%$, indicating that the wells would need to be placed further off from each other (in this example the distance between wells was $30 \mathrm{~m}$ ). The simulations indicated that a 4-well system with $30 \mathrm{~m}$ well distance in a squared formation could work satisfactorily with modest performance loss compared to a single hole system.

As an overall assessment of the deep-heat well system, the thermal analyses of this thesis indicates that it could be a new and promising heat source solution for heat pumps. The technology has clear benefits over traditional shorter boreholes, in particular in the space needed, enabling their use in more dense urban areas. But the analyses done also indicate that the performance of deep-heat systems is sensitive to a range of variables and parameters, 
which urges for careful planning and design of such systems, in particular in geoengineering and thermal engineering fields.

As deep-heat technology is still in a piloting phase in Finland, collecting performance data from real projects would be useful for establishing more firm design guidelines, to which indicative insight were also given in this work. A comprehensive optimization exercise of deep-heat systems would also be relevant and could lay grounds for some standard design which the practitioners in this field could use. 


\section{References}

Acuña, J. 2013. Distributed thermal response tests: New insights on U-pipe and Coaxial heat exchangers in groundwater-filled boreholes. Doctoral Thesis, Kungliga Tekniska Högskolan, Energy and Environmental Technology, Stockholm.

Acuña, J. 2010. Improvements of U-pipe Borehole Heat Exchangers. Licentiate Thesis, Kungliga Tekniska Högskolan, Energy and Environmental Technology, Stockholm.

Aittomäki, A. \& Aalto, E. 2008. Kylmätekniikka, 3. edition, Suomen kylmäyhdistys, Helsinki. ISBN:978-951-96449-6-7 (in Finnish).

Bär, K., Rühaak, W., Welsch, B., Schulte, D. \& Sass, I. 2015. Seasonal high temperature heat storage with medium deep borehole heat exchangers. Energy Procedia, 76, pp. 351360.

Barbier, E. 1997. Nature and technology of geothermal energy: A review. Renewable and Sustainable Energy Reviews, 1, pp.1-69. doi.org/10.1016/S1364.

Bauer, D., Marx, R., Nussbicker-Lux, J., Ochs, F. \& Heidemann, W. 2010. German central solar heating plants with seasonal heat storage. Solar Energy 84, pp. 612-623. doi: 10.1016/j.solener.2009.05.013.

Bear, J. 1979, Hydraulics of groundwater, McGraw-Hill, New York. ISBN:0-07- 004170-9.

Bear, J. 1988, Dynamics of fluids in porous media, repr. edn, Dover, New York. ISBN:0486-65675-6.

Borgnakke, C., Sonntag, R.E. 2009. Fundamentals of thermodynamics. Wiley, 2009.

Byrum HVAC. 2019. https://www.byrumhvac.com/blog/geothermal-vs-heat-pumps-worksbest (accessed 10 September 2019).

Carslaw, H.S., J.C. Jaeger (1959). Conduction of heat in solids. $2^{\text {nd }}$ Edition. Oxford University Press, Oxford.

Cervera, C. 2013.Ground thermal modelling and analysis of energy pile foundations. Master's thesis. School of Engineering, Aalto University, Civil and Environmental Engineering.

Churchill, S.W., Chu, H.H.S. 1975. Correlating Equations for Laminar and Turbulent Free Convection from a Vertical Plate. Int J Heat Mass Transfer, 18, pp. 1323-1329.

Churchill, S.W., Bernstein, M. 1977. A Correlating Equation for Forced Convection From Gases and Liquids to a Circular Cylinder in Crossflow. J. Heat Transfer, 99, pp. 300-307.

Comsol. 2019. https://www.comsol.com/ (accessed 12 September 2019).

Dijkshoorn, L., Speer, S., Pechnig, R. 2013. Measurements and Design Calculations for a Deep Coaxial Borehole Heat Exchanger in Aachen, Germany. International Journal of Geophysics. Volume 2013, Article 916541. doi.org/10.1155/2013/916541

Eskola, L., Jokisalo, J., Siren, K.. 2012. Lämpöpumppujen energialaskentaopas. Aalto Yliopisto. Espoo. (in Finnish) 
Engineering Toolbox. 2019. https://www.engineeringtoolbox.com (accessed 12 September 2019).

Environment.fi. https://www.ymparisto.fi/en-US/Waters/Protection_of_waters/Groundwater_protection/Groundwater_in_Finland (accessed 14 November 2019).

Geologian tutkimuskeskus. 2019. Helsingin geoenergiapotentiaali. Helsingin kaupungin maa- ja kallioperäyksikkö. (in Finnish)

Gehlin S.E.A, Spitler, J.D., Hellström G. 2016. Deep Boreholes for Ground Source Heat Pump Systems - Scandinavian Experience and Future Prospects, ASHRAE Winter Meeting, Orlando Florida, January 23-27, 2016.

Gierup, J. 2015. Personal communication. The Swedish Well Database, Swedish Geological Survey.

Glassley, W. E. 2010. Geothermal Energy: Renewable Energy and the Environment. CRC Press. Boca Raton.

Gnielinski, V. 1976. New equations for heat and mass transfer in turbulent pipe and channel flow. Int. Chem. Eng.,16, pp. 359-368.

Grundfos. 2019. https://uk.grundfos.com/products.html (accessed 1 November 2019).

Hellström, G. 1998. Thermal performance of borehole heat exchangers. Lund Institute of Technology, Sweden.

Hellstöm, G.1991. Ground Heat Storage, Thermal Analysis of Storage Systems. Department of Mathematical Physics, University of Lund. Sweden.

Hellström, G., Kjellsson, E. 2000. Laboratory measurements of heat transfer properties of different types of borehole heat exchangers. Proc. of Terrastock, August 28 - September 1, 2000. Stuttgart, Germany.

Holmberg, H., Acuna J., Naess, E., Sonju O. 2016. Thermal Evaluation of Coaxial Depp Borehole Exchangers. Department of Energy and Process Engineering, Norwegian University of Science and Technology, Renewable Energy.

Holmberg, H. 2016. Transient Heat Transfer in Boreholes with Application to Non-Grouted Borehole Heat Exchangers and Closed Loop Engineered Geothermal Systems. Norwegian University of Science and Technology, Renewable Energy.

Holmberg, H. 2016. Numerical model for non-grouted borehole heat exchangers, Part 2Evaluation. Geothermics, 59(Part A), pp.134-144. doi:10.1016/j.geothermics.2014.11.002.

Homuth, S, Hornich, W. Bär, K. 2016. Down-the-hole water powered hammer drilling for medium deep geothermal energy systems. In: European Geothermal Congress, Strasbourg, 20-22.09.2016.

Homuth, S. 2015. Coupled Renewable Energy Systems for Seasonal High Temperature Heat Storage via Medium Deep Borehole Heat Exchangers. World Geothermal Congress 2015, Melbourne, Australia. 
Huchtemann, K, Müller, K. 2014. Combined simulation of a deep ground source heat exchanger and an office building. Building and Environment, 73, pp. 97-105.

IEA. 2017. Towards a zero-emission, efficient, and resilient buildings and construction sector. Global status report 2017.

Ingrams Water and Air Equipment. 2019. https://www.iwae.com/resources/articles/geothermal-heating-facts.html (accessed 8 November 2019).

Incropera, F., Dewitt, D., Bergman, T., Lavine A. 2007. Fundamentals of heat and mass transfer. $6^{\text {th }}$ Edition. John Wiley \& Sons, New York.

Juvonen, J. \& Lapinlampi, T. 2013. Ympäristöopas 2013. Energiakaivo - Maalämmön hyödyntäminen pientaloissa. Ympäristöministeriö. Helsinki. (in Finnish)

Kangas, MT, Lund PD.1994. Modeling and simulation of aquifer storage energy systems. Solar Energy, 53, pp. 237-247.

Ketonen, J. 2012. Maalämpö lämpöenergian tuottajana. Opinnäytetyö, Rakennustekniikan koulutusohjelma, Kymenlaakson ammattikorkeakoulu. (in Finnish)

Kilpijärvi, A. 2015. Maalämpöpumppujen mitoituksien vertailu, Opinnäytetyö, Oulun ammattikorkeuakoulu, Talotekniikankoulutusohjelma. (in Finnish)

Kohl, T., Brenni, R. Eugster, W.2002. System performance of a deep borehole heat exchanger. Geothermics, 31(6), pp. 687-708. doi:10.1016/S0375-6505(02)00031-7

Kukkonen, I. 2001. Lämpötiloja porakaivoissa 1985 GTK, Rakennustietosäätiö: RT 5010755 Maalämmitys. Rakennustietosäätiö. (in Finnish)

Laitinen, A. 2014. Renewable energy production of Finnish heat pumps. Final report of the SPF-project. VTT Technical Research Centre of Finland. Espoo, Finland.

Lampinen, M.J. 2017. Termodynamiikan perusteet, Otatieto, Finland (in Finnish)

Lund, J.W., Boyd, T.L. 2016. Direct utilization of geothermal energy. 2015 worldwide review. Geothermics, 60, pp. 66-93. doi.org/10.1016/j.geothermics.2015.11.004

Lund, P. 1984. Studies on solar heating systems with long-term heat storage for northern high latitudes. Doctoral Thesis, Helsinki University of Technology, Espoo, Finland.

Lund, P., Östman, B. 1985. A Numerical Model for Seasonal Storage of Solar Heat in the Ground by Vertical Pipes. Solar Energy, 34, pp. 351-366.

Lund, P., Byrne, J., Haas, R., Flynn, D. (eds). 2019. Advances in Energy Systems: The Large-scale Renewable Energy Integration Challenge. John Wiley \& Sons Ltd. ISBN:9781119508311. doi:10.1002/9781119508311.

Lurie, MV. 2008. Modeling of Oil Product and Gas Pipeline Transportation, WILEY-VCH Verlag GmbH \& Co., KGaA, Weinheim.

Löfman, J. 1999. Site scale groundwater flow in Olkiluoto. Posiva report 99-03, Helsinki. 
Moran, M., Shapiro, H., Daisie, B., Bailey, M. 2015. Fundamentals of Engineering Thermodynamic, $8^{\text {th }}$ Edition.

Morita K. 2001. One Possible Way to Utilize Abandoned Deep Wells - the Application of the DCHE. Proceedings Geothermal Energy in Underground Mines, Ustroń, Poland.

Maaskola, I., Kataikko, M. 2014. Ylijäämälämmön taloudellinen hyödyntäminenLämpöpumppu- ja ORC-sovellukset. Motiva. (in Finnish)

Ohk S-M, Chung B-J. 2017. Natural convection heat transfer inside an open vertical pipe: Influences of length, diameter and Prandtl number. International Journal of Thermal Sciences, 115, pp. 54-64.

Pesonen J. 2018. Opinnäytetyö Tekniikka ja liikenne, Rakennus- ja yhdyskuntatekniikka, Insinööri (AMK), Maalämpöjärjestelmän mitoitus ja kustannusarvio, Lapland University of Applied Sciences. (in Finnish)

Peura J. 2017. Maanalaista energiaa, Geoteknisen osaston julkaisu 97, Helsingin kaupunki, Kiinteistövirasto, Geotekninen osasto. ISBN 978-952-331-240-1, ISSN 1458-2198 (in Finnish)

Puranen, J. 2016. Maalämpökentän simulointi. Diplomityö. Tampereen teknillinen yliopisto. (in Finnish)

Rees, S.J. 2016. An introduction to ground source heat pump technology. Advances in ground source heat pump systems, pp. 1-25. Woodhead Publishing, ISBN 9780081003220.

Rindahl C. 2016, Geothermal energy: Model development and analysis of a pilot project. Master Thesis, Department of Energy and Process Engineering, Norwegian University of Science and Technology.

Rybach. L., Hopkirk. C. 1995. Shallow and deep borehole heat exchangers- Achievements and prospects. World Geothermal Congress.

Sanner, B., Karytsas, C., Mendrinos, D. \& Rybach, L. 2003. Current status of ground source heat pumps and underground thermal energy storage and underground thermal energy storage in Europe. Geothermics. Giessen.

Sanner B, Karytsas K, Abry M, Coelho L, Goldbrunner J, Mendrinos D. 2007. GROUNDHIT - Advancement in ground source heat pumps through EU support. European Geothermal Congress.

Scorpo,A. 2013. Heat transfer in borehole heat exchangers and the contribution of groundwater flow. Doctoral Thesis, University of Trieste, Italy.

Śliwa, T., Kruszewski, M., Sapińska-Śliwa, A. \& Assadi, M. 2017. The application of vacuum insulated tubing in deep borehole heat exchangers. AGH Drilling, Oil, Gas, 34(2), pp. 597617. doi:10.7494/drill.2017.34.2.597

Sliwa, T., Kruszewski, M., Zare, A., Assadi, M. \& Sapinska-Sliwa, A. 2018, Potential application of vacuum insulated tubing for deep borehole heat exchangers. Geothermics, 75, pp. 58-67. doi:10.1016/j.geothermics.2018.04.001 
Stevanovic, Z. 2010. Utilization and regulation of springs. In Engineering, theory, management, and sustainability. Elsevier, pp. 339-388.

ST1. 2019. https://www.st1.fi/geolampo (accessed 1 November 2019).

Valtioneuvosto. 2019. Rinteen hallitusohjelma. (in Finnish)

Wallin, B. 1995. Palaeohydrological implications in the Baltic area and its relation to the groundwater at Äspö, south-eastern Sweden - A literature study. SKB technical report SKBTR-95-06, Sweden.

White, F. 2008. Fluid mechanics. $7^{\text {th }}$ Edition. McGraw-Hill Companies, Inc.

Wikipedia. PID-controller. 2019. https://en.wikipedia.org/wiki/PID_controller\#/media/File:PID_en.svg (accessed 1 November 2019).

Åström, K.J. 2002. Control system design. University of California, Santa Barbara. 